JULIANA MOREIRA

Expressão e purificação da quinase dependente de ciclina 13 humana em sistema bacteriano

Dissertação apresentada ao Instituto de Química de São Carlos da Universidade de São Paulo para a obtenção do título de Mestre (Química Orgânica e Biológica).

Orientadora: Profa. Dra. Fernanda Canduri

São Carlos

2014 
Autorizo a reprodução e divulgação total ou parcial deste trabalho, por qualquer meio convencional ou eletrônico, para fins de estudo e pesquisa, desde que citada a fonte.

Ficha catalográfica 
Aos meus pais Luiz Henrique Moreira e Margaret Maria Bonaldo Moreira por sempre me guiarem, pelo apoio e amor incondicional. 


\section{Agradecimentos}

Agradeço a Deus e Nossa Senhora por iluminar meus caminhos.

À minha orientadora Profa. Dra. Fernanda Canduri por todo o conhecimento compartilhado e todos os ensinamentos desde a iniciação científica, pelo apoio e incentivo durante todo o trabalho, confiança e paciência nos momentos mais difíceis.

A todos do grupo do Laboratório de Bioquímica Molecular e Estrutural (BioQEst), Nathalia Rodrigues pela ajuda e sugestões desde a iniciação científica, Cintia Lamas e Nikolas Paparidis pela ajuda e conversas com muitas risadas, Bruna Casali, Denise Pilger, Nathalia Indolfo e Buana Carvalho. Muito obrigada pela amizade de todos.

À Beatriz Miranda pela ajuda e discussões sobre o trabalho, e à Yara Kerber pelas trocas de novas ideias.

Ao meu pai, Luiz Henrique, minha mãe, Margaret e meu irmão, Murilo, pelo apoio e paciência em todos os momentos, interesse pela minha pesquisa, pelo incentivo dado para tudo em minha vida, por estarem do meu lado sempre, muito obrigada, amo demais cada um de vocês.

A todos da minha família que sempre estiveram presentes, Carol, Tia Marta, Vó Marli, Vó Elza, Vô Salvador e minha bisavó Carmen (In memorian).

A Cindia Pacífico, Nayara Cavalheiro, Helder de Assis e Graziela Vanni.

Ao laboratório de Microfabricação e Separações (BioMicS - IQSC/USP), Laboratório do Grupo de Química Medicinal (Nequimed - IQSC/USP), Laboratório de Biologia Molecular do Grupo de Cristalografia (IFSC/USP) e ao Laboratório de Bioquímica Funcional e Estrutural (LBFE - UFSCar) pela parceria na realização de experimentos.

A todos que de alguma forma contribuíram para realização desse trabalho.

Ao CNPq, pela bolsa de mestrado concedida e à FAPESP, pelo auxílio financeiro ao laboratório. 
"No fim tudo dá certo, e se não deu certo é porque ainda não chegou ao fim".

(Fernando Sabino) 


\section{RESUMO}

As quinases dependentes de ciclinas são proteínas que podem ser divididas de acordo com a sua atuação no ciclo celular ou no controle transcricional, elas se tornam ativas em determinadas etapas do ciclo celular dependendo do seu grau de fosforilação e de sua ligação com ciclinas e proteínas inibitórias, e exercem sua função fosforilando outras proteínas envolvidas no ciclo de divisão celular e transcrição influenciando suas atividades, garantindo que cada processo do ciclo ocorra em uma sequência ordenada. A CDK13 faz parte da família de proteínas quinases dependentes de ciclina, pode se ligar a ciclinas do tipo $L$ ou $K$, regula os eventos de "splicing" alternativo, e interage com a proteína Tat do vírus HIV atuando como um possível fator de restrição, sendo que sua superexpressão diminui a produção de algumas proteínas virais suprimindo a produção do vírus. O DNA referente à CDK13 é replicado em células cancerosas, principalmente dos tipos hepático e cólon e reto, sendo um alvo para inibidores para tratamento de câncer. A fim de contribuir para o estudo dessa proteína, o projeto tem como objetivo expressá-la utilizando métodos de tecnologia de DNA recombinante. A sequência de DNA referente à CDK13 foi amplificada pela reação em cadeia da polimerase, após sua purificação, foi inserida no vetor pCR-Blunt e clonada em células de E. coli DH5a competentes. Porém, o DNA não foi liberado pela reação com as enzimas de restrição BamHI e Ndel. As bactérias Rosetta(DE3) transformadas com um plasmídeo sintético e crescidas em meio de auto-indução expressaram a CDK13. Após lise celular e purificação em coluna de $\mathrm{Ni}^{2+}$, a proteína foi detectada por Western Blot. Já as bactérias Rosetta(DE3) transformadas com o plasmídeo sintético modificado (o qual compreende a região do DNA que expressa o bolsão de ligação da $\mathrm{CDK} 13)$, e induzidas em meio LB expressaram a CDK13, porém não foi possível purificá-la em coluna de afinidade ao $\mathrm{Ni}^{2+}$.

Palavras-chave: CDK13, fosforilação, quinases, controle transcricional. 


\begin{abstract}
The cyclin-dependent kinases are proteins that can be classified by their function in the cell cycle or transcriptional control. They are activated in particular steps of the cell cycle depending on their phosphorylation degree, cyclin binding and inhibitory proteins. They act phosphorylating other proteins involved in the cell cycle and transcriptional control, influencing in their activities, ensuring that each step of the cell cycle occur in an ordered sequence. The CDK13 is one of the cyclin-dependent kinases family member, it can bind to $\mathrm{L}$ or $\mathrm{K}$ cyclins, regulates the alternative splicing and interact with HIV Tat protein, acting as a possible restriction factor, its overexpression decreases the production of some viral proteins, and suppresses the virus production. The DNA corresponding to CDK13 is replicated in cancer cells, mainly of hepatic and colon rectal types; therefore it is a target for inhibitors for cancer therapy. In order to contribute for the studies of this protein, the goal of the project is to express it using methods of recombinant DNA technology. The DNA sequence corresponding to CDK13 was amplified by polymerase chain reaction, after its purification, it was inserted to pCR-Blunt vector and cloned into E. coli DH5a competent cells. However, the DNA wasn't released by the BamHI and Ndel restriction enzymes. The Rosetta(DE3) cells transformed with a synthetic plasmid pET28a::CDK13 and grown in auto-induction media expressed the CDK13. After cell lysis and purification by $\mathrm{Ni}^{2+}$ affinity colum, the protein was identified by Western Blot. However, the Rosetta(DE3) cells transformed with the modified synthetic plasmid (that comprehends the DNA region which expresses the binding pocket region) induced in LB media, expressed the CDK13. Yet, it wasn't possible to purify the protein in the $\mathrm{Ni}^{2+}$ affinity column.
\end{abstract}

Keywords: CDK13, phosphorylation, kinases, transcriptional control. 


\section{LISTA DE FIGURAS}

Figura 1 - Ciclo de divisão celular eucariótico.

Figura 2 - Pontos de verificação do ciclo de divisão celular eucariótico.

Figura 3 - Exemplo de uma reação de fosforilação, envolvendo o ATP e o aminoácido serina.

Figura 4 - Processo de ativação de CDKs.

Figura 5 - Mecanismo de regulação da CDK2 por fosforilação e proteólise.

Figura 6 - Estrutura obtida por raios X da CDK2 em complexo com o ATP.

Figura 7 - Representação esquemática da CDK13.

Figura 8 - Representação das primeiras três etapas principais da transcrição: iniciação, pausa e elongação.

Figura 9 - llustração do efeito do complexo Tat-p32-CDK13 na regulação do splicing no HIV.

Figura 10 - Fórmula estrutural do Tamoxifen.

Figura 11 - Fórmulas estruturais do flavopiridol e roscovitina.

Figura 12 - Diagrama das etapas realizadas para obtenção da proteína CDK13 humana.

Figura 13 - Sequência de aminoácidos em código de uma letra da proteína CDK13.

Figura 14 - Gel de agarose $0,8 \%$ mostrando a amplificação do DNA referente à CDK13, em várias temperaturas de anelamento.

Figura 15 - Gel de agarose 0,8\% mostrando a amplificação do DNA referente à CDK13.

Figura 16 - Gel de agarose $0,8 \%$ mostrando o DNA referente à CDK13 purificado a partir de gel de agarose.

Figura 17 - Gel de agarose 0,8\% para análise de recombinantes por PCR de colônias.

Figura 18 - Gel de agarose $0,8 \%$ mostrando o plasmídeo recombinante pCRBlunt::CDK13.

Figura 19 - Gel de agarose $0,8 \%$ mostrando o resultado da clivagem com Ndel e BamHI.

Figura 20 - Gel de agarose 0,8\% mostrando o resultado da clivagem com Ndel e HindllI.

Figura 21 - Sequenciamento automático do DNA referente à CDK13.

Figura 22 - Gel de agarose $0,8 \%$ mostrando os plasmídeos recombinantes purificados.

Figura 23 - Sequenciamento automático do DNA referente à CDK13 sintético.

Figura 24 - Gel de agarose 0,8\% para análise do produto das reações de PCR com o plasmídeo recombinante pET28a::CDK13 como molde para obter o vetor e parte da sequência da CDK13, para obter um DNA de $1017 \mathrm{pb}$ correspondente à CDK13, mais $5369 \mathrm{pb}$ do vetor pET28(+), totalizando um plasmídeo de expressão de 6386pb. 
Figura 25 - Gel de agarose $0,8 \%$. a) Reação de PCR com temperatura de anelamento $60,6^{\circ} \mathrm{C}$. b) Plasmídeo recombinante de expressão modificado purificado a partir de gel de agarose.

Figura 26 - Gel de agarose 0,8\%. Análise de recombinantes por PCR de colônia.

Figura 27 - Gel de poliacrilamida $12 \%$ para verificação da expressão da amostra de indução em células BL21(DE3)pLysS, com $0,1 \mathrm{mM}$ de IPTG, a $20^{\circ} \mathrm{C}$ por 15 horas.

Figura 28 - Gel de poliacrilamida $12 \%$ para verificação da expressão da amostra de indução em células BL21(DE3)pLysE, com $0,2 \mathrm{mM}$ de IPTG, a $30^{\circ} \mathrm{C}$ por 4 horas.

Figura 29 - Gel de poliacrilamida 12\% para verificação da indução em células BL21(DE3) com $0,1 \mathrm{mM}$ de IPTG, a $30^{\circ} \mathrm{C}$, por 4 horas.

Figura 30 - Gel de poliacrilamida $12 \%$ da indução em células BL21(DE3) com 0,1mM de IPTG, a $20^{\circ} \mathrm{C}$, por 15 horas.

Figura 31 - Gel de poliacrilamida 12\% da indução em células BL21(DE3) com 0,1mM de IPTG, a $37^{\circ} \mathrm{C}$, por 4 horas.

Figura 32 - Gel de poliacrilamida $12 \%$ da indução em células Rosetta(DE3) com 0,2mM de IPTG, a $20^{\circ} \mathrm{C}$, por 24 horas.

Figura 33 - Gel de poliacrilamida 12\% das amostras do teste de lise com o tampão $A$ da amostra de indução em BL21(DE3).

Figura 34 - Gel de poliacrilamida 12\% das amostras do teste de lise com o tampão B da amostra de indução em BL21(DE3).

Figura 35 - Alinhamento das sequências do domínio quinase das CDKs, as extensões $\mathrm{N}$ e C terminais foram excluídas.

Figura 36 - Alinhamento das sequências de aminoácidos da CDK12 e da CDK13

Figura 37 - Alinhamento das sequências de aminoácidos da CDK9 e da CDK13.

Figura 38 - Modelo estrutural da proteína CDK13 obtido a partir da CDK12 como molde, utilizando modelagem por homologia.

Figura 39 - Modelo estrutural da proteína CDK13 obtido a partir da CDK9 como molde, utilizando modelagem por homologia.

Figura 40 - Sequência de aminoácidos em código de uma letra da proteína CDK13 a ser expressa pelo plasmídeo sintético modificado.

Figura 41 - Gel de poliacrilamida 12\% da indução em células BL21(DE3)pTGroE com $0,2 \mathrm{mM}$ de IPTG, a $30^{\circ} \mathrm{C}$, por 15 horas.

Figura 42 - Gel de poliacrilamida $12 \%$ da indução em células Origami(DE3) com 0,2mM de IPTG, a $30^{\circ} \mathrm{C}$, por 15 horas.

Figura 43 - Gel de poliacrilamida 12\% da indução em células Rosetta(DE3) e BL21(DE3) com $0,2 \mathrm{mM}$ ou $0,4 \mathrm{mM}$ de IPTG, a $20^{\circ} \mathrm{C}$, por 15 horas.

Figura 44 - Gel de poliacrilamida $12 \%$ da indução em células Rosetta(DE3) a $20^{\circ} \mathrm{C}$, por 15 horas. 
Figura 45 - Gel de poliacrilamida $12 \%$ da lise celular da indução em Rosetta(DE3) com $0,2 \mathrm{mM}$ de IPTG, a $20^{\circ} \mathrm{C}$, por 15 horas.

Figura 46 - Gel de poliacrilamida $12 \%$ da lise celular por "freezing and thawing" da indução em células Rosetta(DE3) com $0,2 \mathrm{mM}$ de IPTG, a $20^{\circ} \mathrm{C}$, por 15 horas.

Figura 47: Gel de poliacrilamida $12 \%$ da indução em células Rosetta(DE3), transformação com plasmídeo sintético com $0,2 \mathrm{mM}$ de IPTG, a $20^{\circ} \mathrm{C}$, por 72 horas.

Figura 48 - Gel de poliacrilamida $12 \%$ da indução em células Rosetta(DE3), transformação com plasmídeo sintético modificado com $0,2 \mathrm{mM}$ de IPTG, a $20^{\circ} \mathrm{C}$, por 72 horas.

Figura 49 - Gel de poliacrilamida $12 \%$ da lise de células Rosetta(DE3), transformação com plasmídeo sintético, indução com $0,2 \mathrm{mM}$ de IPTG, a $20^{\circ} \mathrm{C}$, por 72 horas.

Figura 50 - Gel de poliacrilamida $12 \%$ para análise da purificação em coluna de $\mathrm{Ni}^{2+}$.

Figura 51 - Gel de poliacrilamida 12\% mostrando os produtos de expressão em meio de auto-indução durante a purificação em coluna de $\mathrm{Ni}^{2+}$.

Figura 52 - Gel de poliacrilamida 12\% mostrando os produtos de expressão em meio de auto-indução durante a purificação em coluna de ATP.

Figura 53 - Membrana de nitrocelulose do experimento de Western Blot para análise da CDK13 expressa em meio de auto-indução.

Figura 54 - Membrana de nitrocelulose do experimento de Western Blot para análise da CDK13.

Figura 55 - Distribuição da frequência do uso de códons ao longo da sequência do DNA referente à CDK13 a ser expressa em E.coli. 


\section{LISTA DE TABELAS}

Tabela 1 - Dados de 2008 e estimativas para o ano de 2030 mundialmente e estimativas para 2014 no Brasil, dos números de mortes e casos de câncer.

Tabela 2 - Os tipos de cânceres que mais causaram mortes em 2008, os tipos mais comuns, e os mais letais.

Tabela 3 - Sequências dos primers utilizados na amplificação do DNA referente à CDK13.

Tabela 4 - Reação de PCR para a amplificação do DNA referente à CDK13.

Tabela 5 - Programa do termociclador utilizado para a amplificação do DNA referente à CDK13.

Tabela 6 - Reação de PCR de colônias com a enzima $2 x$ Phusion Master Mix, para confirmação da obtenção de colônias positivas para DNA referente à CDK13.

Tabela 7 - Programa do termociclador utilizado no PCR de colônias para confirmação da obtenção do DNA referente à CDK13.

Tabela 8 - Reação de PCR de colônias com a enzima Taq DNA polymerase para confirmação da obtenção de colônias positivas para DNA referente à CDK13.

Tabela 9 - Programa do termociclador utilizado no PCR de colônias para confirmação da obtenção do DNA referente à CDK13.

Tabela 10 - Sequências dos primers utilizados na amplificação do DNA referente ao sítio de ligação da CDK13.

Tabela 11 - Reação de PCR com a enzima Taq DNA polymerase para amplificação do plasmídeo recombinante $\mathrm{pET} 28:: \mathrm{CDK} 13$

Tabela 12 - Programa do termociclador utilizado para amplificação do plasmídeo recombinante pET28::CDK13.

Tabela 13 - Cepas utilizadas nos testes de expressão e suas características principais.

Tabela 14 - Composição do meio de auto-indução ZYP-5052.

Tabela 15 - Principais resultados obtidos na expressão e lise para recuperação da CDK13 utilizando o plasmídeo recombinante pET28a::CDK13 sintético.

Tabela 16 - principais resultados obtidos na expressão e lise celular para recuperação da CDK13 obtida utilizando o plasmídeo recombinante pET28a::CDK13 sintético modificado.

Tabela 17 - Principais resultados obtidos da expressão e lise celular para recuperação da CDK13 obtida com o plasmídeo recombinante pET28a::CDK13 sintético e o modificado em meio de auto-indução.

Tabela 18 - Principais resultados dos experimentos de purificação da proteína CDK13.

Tabela 19 - Principais resultados dos experimentos de Western Blot.

Tabela 20 - Valores de CAl e porcentagem de GC para diferentes regiões da CDK13. 


\section{LISTA DE ABREVIATURAS E SIGLAS}

\begin{tabular}{|c|c|}
\hline$\AA$ & Angstron ( $1 \times 10^{-10}$ metros $)$ \\
\hline$\stackrel{\circ}{ } \mathrm{C}$ & Unidade de temperatura - graus Celsius \\
\hline$\% G C$ & Porcentagem de nucleotídeos citosina e guanina \\
\hline ADP & Adenosina 5 ' difosfato \\
\hline AIDS & Síndrome da imunodeficiência adquirida \\
\hline ATP & Adenosina 5 ' trifosfato \\
\hline BLAST & Basic Local Alignment Search Tool \\
\hline CAI & Codon Adaptation Index \\
\hline CAK & Quinase ativadora de CDKs \\
\hline cDNA & DNA complementar \\
\hline CDK & Quinase dependente de ciclina \\
\hline CK & Citoqueratina \\
\hline CKI & Quinase inibidora de CDKs \\
\hline CTD & Domínio carboxi-terminal \\
\hline $\mathrm{Da}$ & Dalton, unidade de massa atômica \\
\hline DBRP & $\begin{array}{l}\text { Proténa de reconhecimento da caixa de destruição (Destruction } \\
\text { box recognition protein) }\end{array}$ \\
\hline DDR & Proteínas de resposta a danos ao DNA (DNA damage response) \\
\hline DMSO & Dimetilsulfóxido \\
\hline DNA & Ácido desoxirribonucleico \\
\hline ddNTP & 2',3' - dideoxirribonucleosídeos trifosfatados \\
\hline dNTP & Desoxirribonucleosídeos trifosfatados \\
\hline DTT & Ditiotreitol \\
\hline EDTA & Ácido etilenodiaminotetracético \\
\hline Fw & Forward \\
\hline IARC & International Agency for Research on Cancer \\
\hline INCA & Instituto Nacional de Câncer \\
\hline IPTG & Isopropil- $\beta$-D-1-tiogalactopiranosídeo \\
\hline $\mathrm{kDa}$ & $10^{3}$ unidades de massa atômica \\
\hline LB & Luria-Bertani \\
\hline $\mathrm{NCBI}$ & National Center of Biotechnology Information \\
\hline $\mathrm{nm}$ & Nanômetro ( $10^{-9}$ metros $)$ \\
\hline $\mathrm{pb}$ & Par de bases \\
\hline PCR & Reação em cadeia da polimerase \\
\hline PSA & Persulfato de amônio \\
\hline
\end{tabular}




$\begin{array}{cl}\text { P-TEFb } & \text { Fator positivo de elongação da transcrição } \\ \text { RNA } & \text { Ácido ribonucleico } \\ \text { RNAPII } & \text { RNA polimerase II } \\ \text { RNAm } & \text { RNA mensageiro } \\ \text { Rv } & \text { Reverse } \\ \text { SDS } & \text { Dodecil sulfato de sódio } \\ \text { SDS-PAGE } & \text { Eletroforese em gel de poliacrilamida em presença de SDS } \\ \text { SnRNP } & \text { Pequenas partículas ribonucleicas nucleares (Small nuclear } \\ & \text { ribonucleic particles) } \\ \text { Tat } & \text { Proteínas transativadoras (Trans-activating protein) } \\ \text { TEMED } & \text { N,N,N,N'- tetrametilenodiamina } \\ \text { T-FIIH } & \text { Fator de transcrição humano II (Human transcription factor II) } \\ \text { Tm } & \text { Temperatura de melting ou anelamento } \\ \text { WHO } & \text { World Health Organization }\end{array}$




\section{SUMÁRIO}

1 INTRODUÇÃO 17

1.1 Ciclo de divisão celular 17

1.2 Controle do ciclo de divisão celular mediado por CDKs 19

1.3 Mecanismos regulatórios das atividades das CDKs 20

1.4 Classificação das CDKs baseada em suas funções 25

1.4.1 Características da CDK12 e da CDK13 26

1.4.2 Funções da CDK12 e da CDK13 27

1.4.3 Doenças relacionadas à CDK12 e à CDK13 31

1.5 CDKs como alvos para tratamento de câncer 34

1.6 Câncer 36

1.6.1 Dados estatísticos 36

1.6.2 Células cancerosas: características e desenvolvimento 38

2 OBJETIVOS 40

3 MATERIAIS E MÉTODOS 41

3.1 Obtenção da sequência de nucleotídeos da CDK13 42

3.2 Construção dos oligonucleotídeos iniciadores (primers) 42

3.3 Clonagem e Subclonagem 43

3.3.1 Reação em cadeia da polimerase (PCR) 43

3.3.2 Eletroforese em gel de agarose 45

3.3.3 Purificação do DNA a partir do gel de agarose 46

3.3.4 Ligação ao vetor de clonagem 46

3.3.5 Preparação de células $\mathrm{DH} 5 \alpha \mathrm{CaCl}_{2}$ competentes 47

3.3.6 Transformação em células $\mathrm{DH} 5 \alpha \mathrm{CaCl}_{2}$ competentes 47

3.3.7 PCR de colônias 48

3.3.8 Preparação de pré-inóculo 50

3.3.9 Purificação dos plasmídeos recombinantes 51 
3.3.10 Reação de clivagem para liberação do DNA referente à CDK13 51

3.3.11 Construção do plasmídeo recombinante de expressão 51

3.3.12 Obtenção dos plasmídeos recombinantes de expressão 52

3.3.13 Sequenciamentos 52

3.3.14 Modificação do plasmídeo recombinante pET28a::CDK13 53

3.4 Expressão 55

3.4.1 Testes de expressão 55

3.4.2 Testes de expressão em meio de auto-indução 57

3.4.3 Gel de poliacrilamida $12 \%$ para análise dos testes de indução 60

3.4.4 Lise das células 61

3.5 Purificação 62

3.5.1 Coluna de afinidade ao $\mathrm{Ni}^{2+}$ 62

3.5.2 Coluna de afinidade ao ATP 63

3.6 Western Blot 63

4 RESULTADOS E DISCUSSÃO 66

4.1 Obtenção da sequência de nucleotídeos da CDK13 66

4.2 Clonagem 67

4.2.1 Amplificação do DNA referente à CDK13 por PCR 67

4.2.2 Obtenção do plasmídeo recombinante de clonagem pCR-Blunt::CDK13

4.2.3 Reação de clivagem para liberação do DNA referente à CDK13 71

4.2.4 Construção do plasmídeo recombinante de expressão pET28a::CDK13

4.2.5 Obtenção do plasmídeo recombinante pET28a::CDK13 após modificação 75

4.3 Expressão 78

4.3.1 Expressão e lise para recuperação da CDK13 obtida com o plasmídeo recombinante pET28a::CDK13 sintético

4.3.2 Expressão e lise para recuperação da CDK13 obtida com o plasmídeo recombinante $\mathrm{pET} 28 \mathrm{a}:$ :CDK13 sintético modificado 
4.3.3 Expressão e lise para recuperação da CDK13 obtida com o plasmídeo recombinante pET28a::CDK13 sintético e sintético modificado, em meio de auto-indução

4.4 Purificação 95

4.4.1 Purificação da CDK13 da expressão em meio LB com plasmídeo sintético modificado 95

4.4.2 Purificação da CDK13 da expressão em meio de auto-indução com plasmídeo sintético 96

4.5 Western Blot 99

5 CONCLUSÕES 105 


\section{INTRODUÇÃO}

\subsection{Ciclo de divisão celular}

A divisão celular em eucariotos ocorre em quatro fases: S, M, G1 e G2 (Figura 1).

Na fase S, o DNA é replicado; em seguida, na fase G2, novas proteínas são sintetizadas e a célula praticamente dobra de tamanho; na fase $M 0$ envelope celular é degradado, os cromossomos pareados são puxados para os pólos da célula, cada conjunto de cromossomos filhos é envolto por um novo envelope nuclear terminando assim com a citocinese, a divisão da célula em duas células-filhas no processo de mitose. ${ }^{1}$

Figura 1 - Ciclo de divisão celular eucariótico. As durações de cada etapa variam com o tipo de célula, porém essas são as mais frequentes.

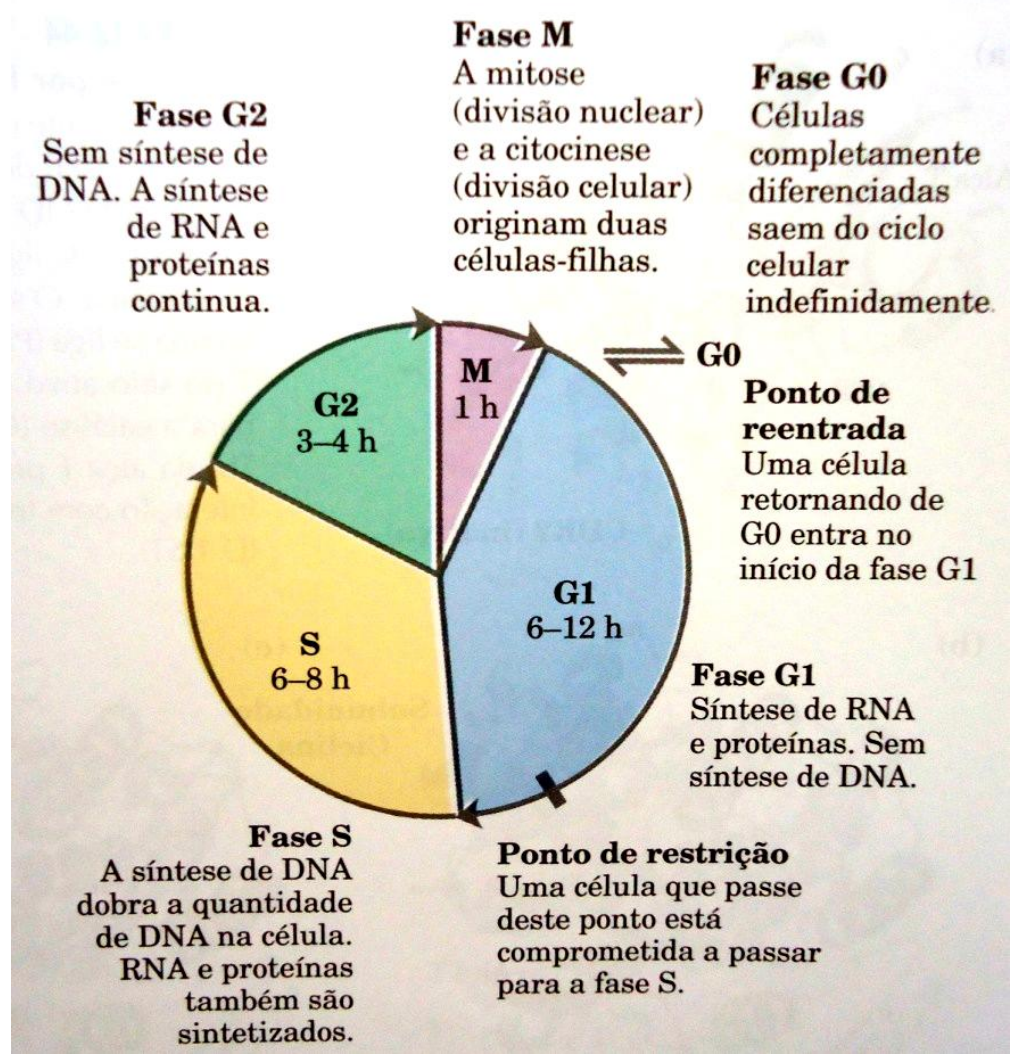

Fonte: NELSON, D. L., 2011, p. 469. ${ }^{1}$ 
Após a divisão celular, a célula entra na fase G1, na qual ocorre a síntese de proteínas e RNA. Em seguida, a célula pode entrar novamente na fase $S$, continuar o ciclo e sofrer outra divisão, ou entrar numa fase quiescente, chamada G0, que pode durar horas, dias ou toda a vida da célula. ${ }^{1}$

Quando a célula em G0 entra em divisão novamente ela reinicia pela fase G1. Durante o crescimento embrionário e desenvolvimento, a divisão celular ocorre em praticamente todos os tecidos, porém no organismo adulto, a maioria das células entra na fase quiescente. ${ }^{1}$

A decisão da célula de proliferar ou entrar na fase G0 ocorre no ponto de verificação chamado ponto de restrição do final da fase G1. O sistema de controle do ciclo responde a sinais intra e extracelulares e interrompe o ciclo quando há alguma falha ou encontra condições desfavoráveis como quando há pouca disponibilidade de nutrientes ou se estiver em contato com outras células levando à célula à fase $\mathrm{G} 0 .^{2,3}$

Entretanto, a célula pode decidir por proliferar na presença de vários agentes como proteínas chamadas mitógenos que são reconhecidos por receptores da superfície da célula aos quais se ligam e induzem a divisão em condições favoráveis, carcinógenos e vírus causadores de tumor, ou pela remoção cirúrgica de um tecido que induz sua regeneração. ${ }^{2,3,4}$

Durante o ciclo existem, além do ponto de restrição em G1, outros pontos de verificação (Figura 2) como, por exemplo, o ponto de verificação G2/M, em que o sistema de controle desencadeia os eventos iniciais da mitose e o ponto de verificação entre a metáfase e a anáfase, que leva à finalização da mitose e citocinese. Nestes pontos, os sistemas de controle do ciclo monitoram se a célula completou satisfatoriamente a fase anterior para que se inicie a próxima fase..$^{2,3,4}$ 
Figura 2 - Pontos de verificação do ciclo de divisão celular eucariótico. O controlador representa os sistemas de controle do ciclo de divisão celular que atuam no ponto de restrição em G1, no ponto de verificação G2/M e no ponto de verificação entre as etapas de metáfase e anáfase.

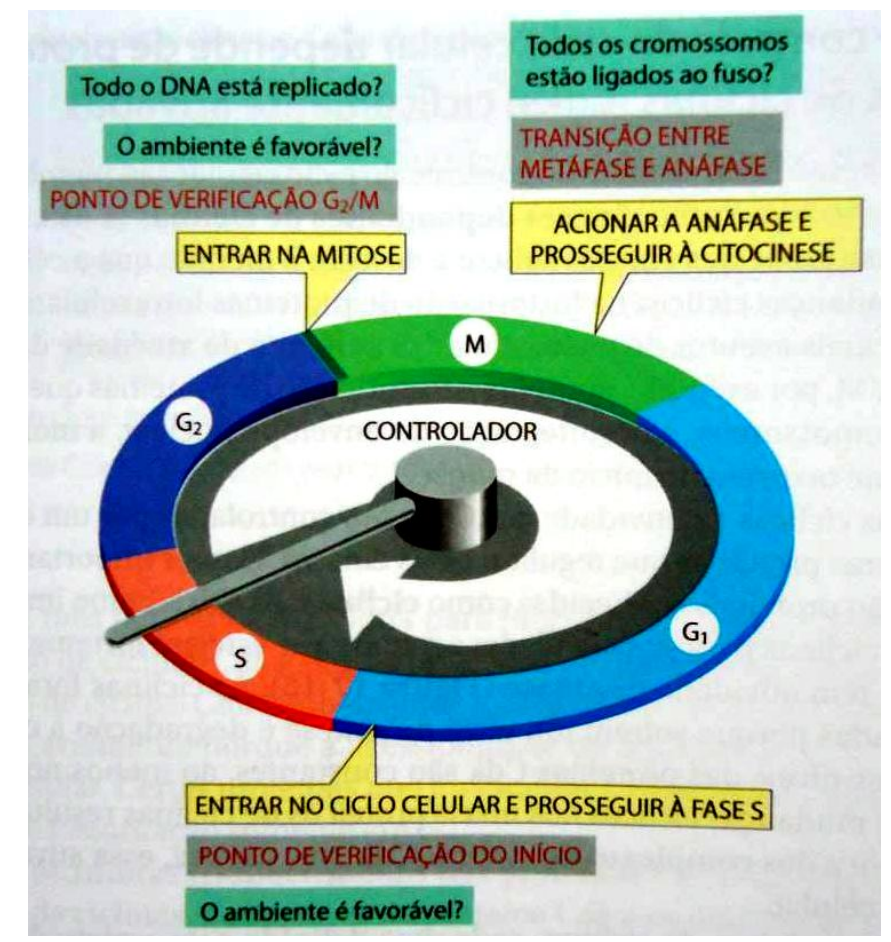

Fonte: ALBERTS, B., 2010, p. 1061 . $^{2}$

\subsection{Controle do ciclo de divisão celular mediado por CDKs}

As quinases dependentes de ciclina (CDKs - "cyclin dependent kinases") são proteínas envolvidas com etapas críticas dos processos que ocorrem nas células, como o ciclo celular e transcrição, e suas atividades dependem de subunidades específicas chamadas ciclinas. ${ }^{5}$ Elas são os componentes centrais do sistema de controle do ciclo celular desencadeando e sincronizando seus eventos para que ocorram em uma sequência determinada e a divisão ocorra corretamente. ${ }^{2}$

As CDKs de mamíferos formam uma "rede" que controla a progressão ao longo das quatro fases sucessivas: G1, S, G2 e M ou a permanência da célula na fase quiescente G0. As CDKs atuam em função da presença de fatores de crescimento e tendem a estabilizar o estado estacionário 
correspondente a fase quiescente, entretanto, na presença de quantidades suficientes de fatores de crescimento, ocorrem oscilações nas atividades das CDKs que levam a ativação sequencial de vários complexos ciclina/CDK, permitindo a progressão correta das sucessivas fases do ciclo celular. ${ }^{6}$

Em células eucarióticas, quatro complexos de ciclina/CDK principais são produzidos, nomeados G1-CDK, G1/S-CDK, S-CDK e M-CDK, cada um capaz de fosforilar diferentes grupos de proteínas atuando nos mecanismos moleculares que regulam a proliferação celular. A Figura 3 apresenta um esquema de uma reação de fosforilação promovida pelas CDKs. ${ }^{4,10}$

Figura 3 - Exemplo de uma reação de fosforilação, envolvendo o ATP e o aminoácido serina. A formação da fosfoserina é promovida pela CDK.

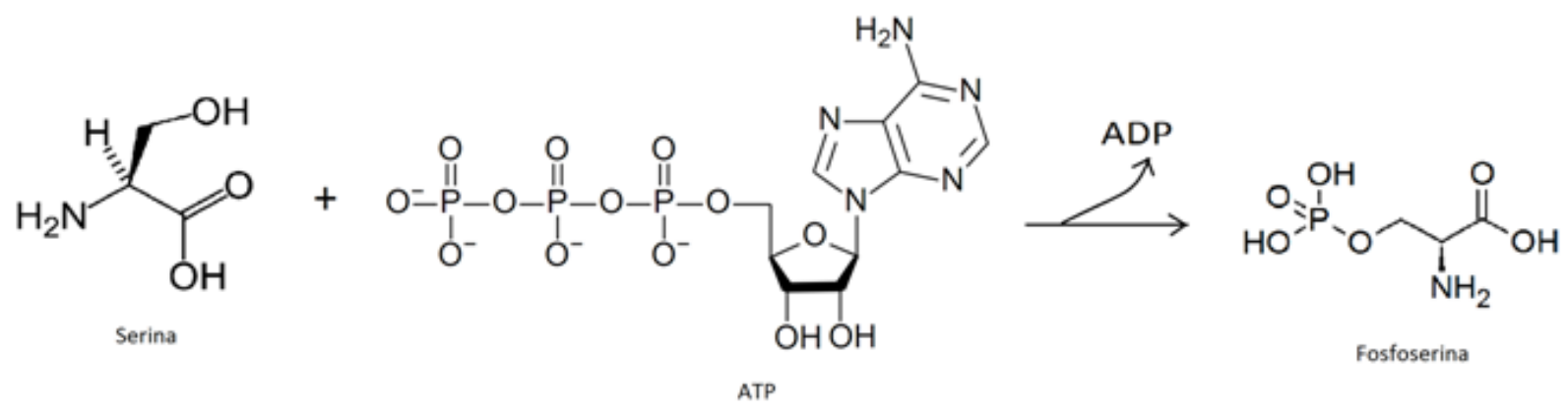

Fonte: WIKIMEDIA. ${ }^{7,8,9}$

As oscilações nas atividades das CDKs ocorrem pelo mecanismo de controle sobre as CDKs. ${ }^{1}$

\subsection{Mecanismos regulatórios das atividades das CDKs}

Os quatro principais mecanismos regulatórios das atividades das CDKs são: ativação da CDK pela ligação à ciclina, ativação por fosforilação, inibição por fosforilação e inibição por subunidades (proteínas) inibitórias chamadas CKIs. ${ }^{11}$ Outros mecanismos incluem a degradação das ciclinas, síntese periódica das ciclinas e das próprias CDKs, ${ }^{1}$ proteólise mediada por ubiquitina, ${ }^{12}$ transcrição e tradução das subunidades, interação com vários inibidores (p16, p21) e modificações em suas localizações celulares. ${ }^{13}$ 
O mecanismo primário de ativação de CDKs é sua ligação à subunidade ciclina, a qual é nomeada assim por causa da flutuação em suas concentrações durante o ciclo celular. ${ }^{4}$

O processo total de ativação da CDK é caracterizado por três estágios (Figura 4): na etapa inativa, a CDK se encontra como proteína monomérica, na etapa parcialmente ativa, se forma o complexo ciclina/CDK, e na etapa ativa, ocorre a fosforilação de uma treonina conservada do complexo pelas CAKs (quinases ativadoras de CDKs). ${ }^{4}$

Figura 4 - Processo de ativação de CDKs. O processo pode ser dividido em três etapas: inativa, com a CDK monomérica, parcialmente ativa, quando a CDK se liga à ciclina, e ativa, quando uma treonina conservada é fosforilada por uma CAK.

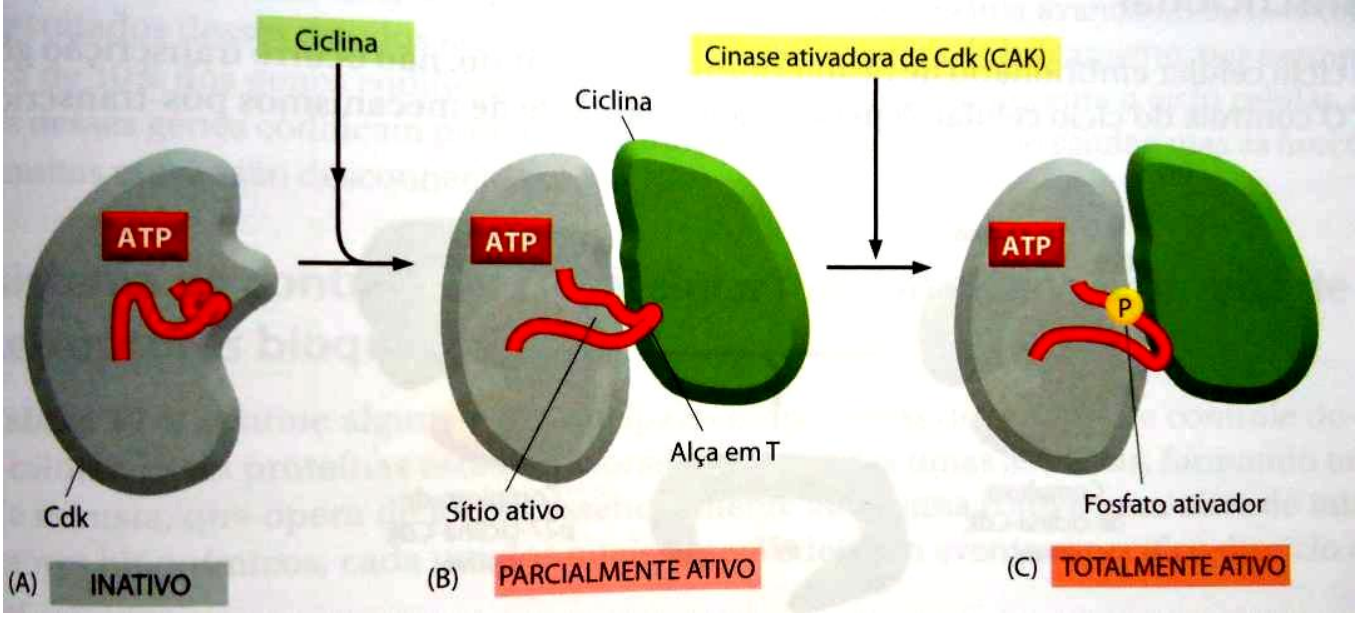

Fonte: ALBERTS, B., 2010, p.1063. ${ }^{2}$

O complexo completamente ativo pode ser desligado por vários mecanismos, como pelas subunidades inibitórias de CDKs, as CKIs, que podem se ligar e inibir os complexos ciclina/CDKs, ou quinases regulatórias que podem fosforilar a subunidade CDK em sítios inibitórios no domínio $\mathrm{N}$ terminal. ${ }^{14}$

Os mecanismos regulatórios das CDKs são projetados para gerar mudanças rápidas e persistentes em suas atividades, usando feedbacks positivos que aceleram as mudanças em sua atividade quando um evento crítico se inicia. ${ }^{14,15}$

A concentração de CDKs não muda significativamente durante o ciclo celular, mas são ativadas e desativadas com o avanço do ciclo. Essas 
mudanças são interligadas e não só acionam os eventos do ciclo, como também iniciam a ativação do próximo complexo ciclina/CDK em série. Já as concentrações de ciclinas e CKls são estreitamente controladas, temporal e espacialmente, fornecendo uma regulação precisa dos eventos do ciclo. ${ }^{14,15}$

Um mesmo tipo de CDK pode atuar em diferentes eventos do ciclo celular, pois as ciclinas conferem diferenças em sua especificidade pelos substratos ou podem marcar a CDK para uma localização subcelular específica que altera a viabilidade de substratos para fosforilação. ${ }^{14}$

Muitos mecanismos regulatórios atuam causando mudanças conformacionais na estrutura das CDKs. O monômero da CDK consiste de um domínio $\mathrm{N}$-terminal rico em folhas $\beta$, um domínio $\mathrm{C}$-terminal rico em $\alpha$-hélices e um domínio catalítico responsável pela ligação do ATP escondido entre os domínios N e C terminais; e duas estruturas de controle, o T-loop ou alça T e uma $\alpha$-hélice que contém uma sequência de aminoácidos bastante conservada e que está presente apenas em CDKs. ${ }^{14}$

Alguns exemplos de mecanismos regulatórios já estudados são os exercidos sobre a CDK2.

Quando a CDK2 é fosforilada em sua tirosina 15 (Tyr15), ela é inativada, pois este resíduo se encontra no sítio ativo da proteína, e a fosforilação impede a ligação do ATP, uma fosfatase desfosforila a Tyr15 permitindo sua ligação ao ATP. ${ }^{1}$

Quando a ciclina se liga a CDK2, a a-hélice (contendo a sequência PSTAIRE na CDK2) se move em direção ao domínio catalítico trazendo o resíduo de glutamato (E51) pra dentro, o que é importante para permitir que o ATP interaja com o sitio catalítico, enquanto a alça T se curva em direção ao domínio C-terminal. A fosforilação da Thr160 na alça T, catalisada por uma quinase ativadora da CDK (CAK), desloca a alça $T$ para fora da fenda de ligação do substrato, expondo o sitio catalítico e facilitando a ligação do ATP, aumentando a atividade catalítica da CDK2. ${ }^{1,4}$

As ciclinas $A$ e $B$ possuem uma sequência de resíduos de aminoácidos chamada de "caixa de destruição". A proteína de reconhecimento da caixa de destruição (DBRP - "destruction box recognition protein") reconhece esta sequência e inicia o processo de degradação ligando à ciclina moléculas de 
ubiquitina ativadas que são reconhecidas pelo complexo enzimático proteolítico, que a degrada. ${ }^{1}$ A Figura 5 mostra um esquema destes mecanismos regulatórios e a Figura 6 apresenta a estrutura obtida por raios $X$ da CDK2 em complexo com o ATP.

Figura 5 - Mecanismo de regulação da CDK2 por fosforilação e proteólise. A alça T quando é fosforilada se movimenta para fora do sítio de ligação do substrato, ativando a CDK. O complexo ciclina/CDK inicia sua inibição ao fosforilar a proteína DBRP (proteína de reconhecimento da caixa de destruição), que se une a ubiquitina ligase, provocando a ligação de várias moléculas de ubiquitina à ciclina, marcando-a para destruição por proteossomos.

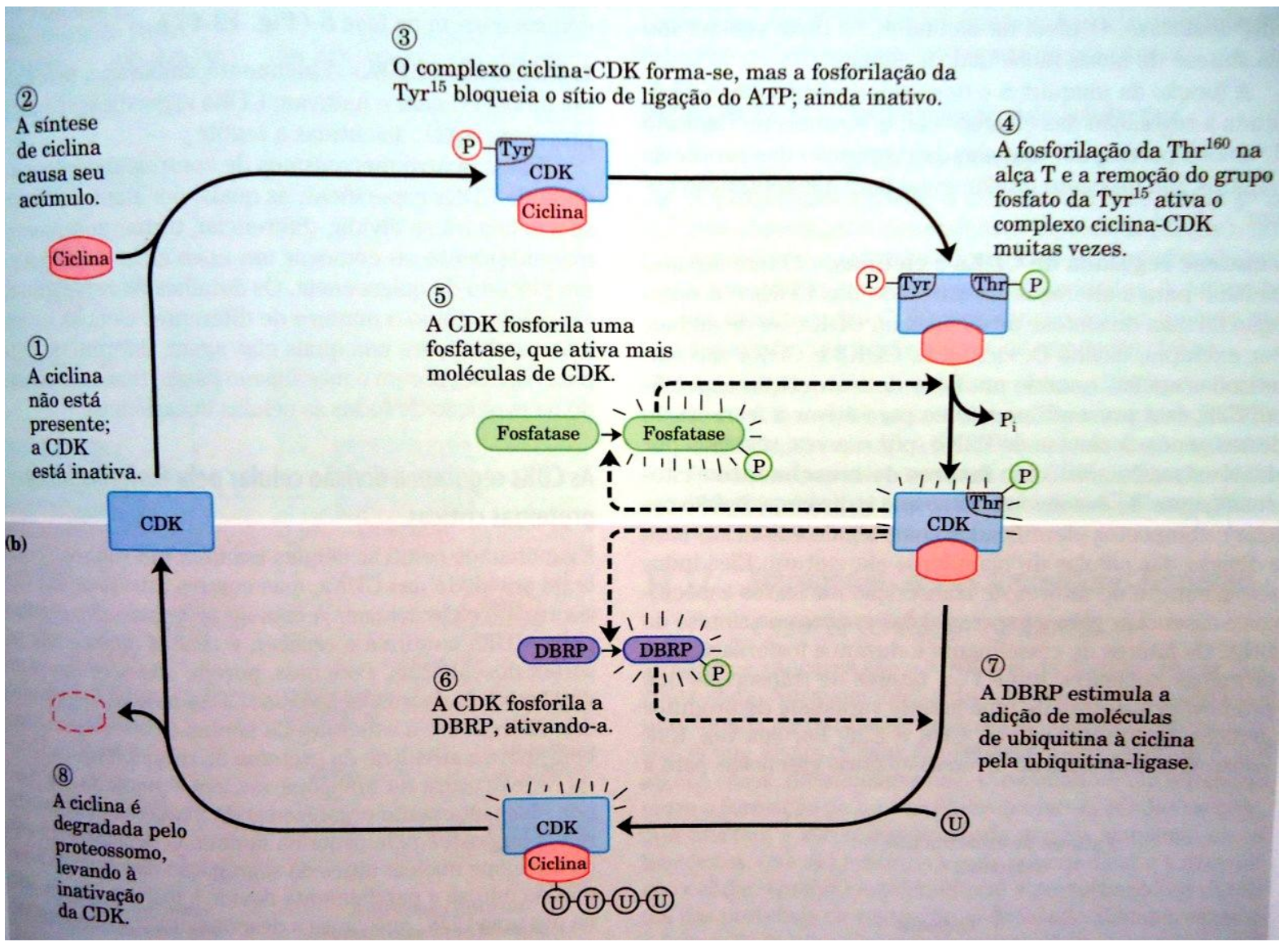

Fonte: NELSON, D. L., 2011, p. $471^{1}$ 
Figura 6 - Estrutura obtida por raios X da CDK2 em complexo com o ATP. O domínio $\mathrm{N}$-terminal está colorido em rosa, o C-terminal em ciano, a hélice PSTAIRE em magenta e a alça T em laranja. O ATP está representado em modelo de esferas e as cadeias laterais dos resíduos de aminoácidos Thr 14, Tyr 15 e Thr 160 fosforilados estão representados em forma de bastões.

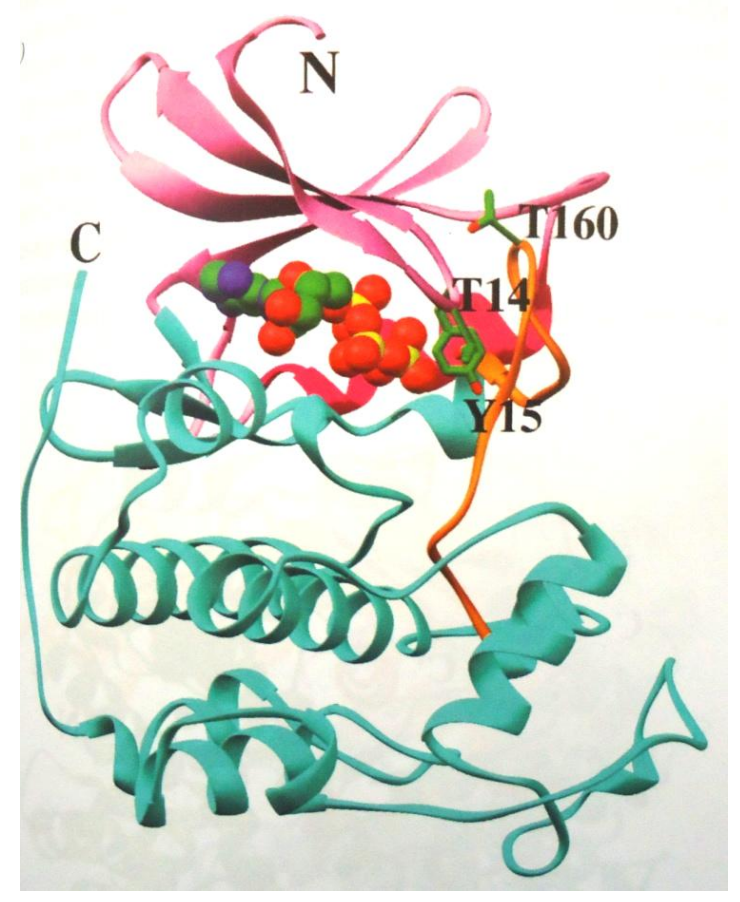

Fonte: VOET, D., 2006, p. 1499. ${ }^{3}$

O mecanismo regulatório da atividade das CDKs pela síntese regulada das CDKs e das ciclinas tem como exemplo as ciclinas E e D e CDKs 2 e 4 que são sintetizadas apenas quando o fator de transcrição E2F está presente para ativar a transcrição desses genes. ${ }^{1}$

Um exemplo de proteínas CKIs são as da família Cip/Kip, que se ligam e inibem a atividade das ciclina E/CDK2 e ciclina A/CDK2, envolvidas na replicação do DNA. Qualquer atividade inibitória das Cip/Kip deve ser banida antes de iniciar a replicação. Isso é alcançado pela proteólise dessas proteínas, e requer a fosforilação da Kip pela CDK9 para ocorrer. ${ }^{15}$ As CKIs, geralmente se ligam às CDKs e alteram a estrutura do sítio ativo da enzima, mantendo-a na sua forma inativa. ${ }^{3}$ Já o subgrupo de proteínas chamadas Cks (citoqueratinas), encontrado em células epiteliais aumentam a atividade das CDKs. ${ }^{16}$ 


\subsection{Classificação das CDKs baseada em suas funções}

Baseado na similaridade de sequências de aminoácidos depositadas em bancos de dados foi descoberto que o genoma humano contém 21 genes que codificam CDKs e cinco outros genes adicionais que codificam um grupo mais distante de proteínas conhecidas como "CDK like" (CDKL). ${ }^{5}$ As CDKs exibem uma alta homologia sequencial. As CDK1-9 e CDK11 podem ser classificadas de acordo com sua função celular no ciclo celular ou transcrição. ${ }^{17}$

As primeiras CDKs a serem descritas foram as reguladoras do ciclo celular, as CDKs 1 (Cdc2), 2, 3, 4 e 6. ${ }^{18}$ Os complexos ciclina D/CDK4-6 e ciclina E/CDK2 promovem a progressão em G1 e suscitam a transição G1/S, respectivamente. $\mathrm{O}$ complexo ciclina $\mathrm{A} / \mathrm{CDK} 2$ garante a progressão da fase $\mathrm{S}$ e a transição S/G2. O complexo ciclina B/CDK1 promove a transição G2/M. ${ }^{6}$ Outra função do complexo ciclina D/CDK4 é regular o crescimento celular e metabolismo, integrando os dois processos. ${ }^{19}$

Outro grupo possui atividades independentes do ciclo celular, como a ciclina H/CDK7 e a ciclina T/CDK9, esses complexos estão envolvidos na regulação da transcrição e no processamento pós-transcricional do RNA mensageiro (RNAm) pela fosforilação do domínio C-terminal (CTD) da RNA polimerase II (RNAPII) e outros reguladores transcricionais. ${ }^{18}$

O complexo ciclina T/CDK9 está localizado em regiões ricas em fatores de splicing, conhecidos como manchas (speckles) nucleares, e atua neste processo. A CDK8 se comporta como reguladora da transcrição de RNA mensageiro, e a CDK5 está envolvida com o desenvolvimento e manutenção do sistema nervoso central. ${ }^{17}$ A CDK5 é ativada pela glicose e insulina em células $\beta$ do pâncreas e adipócitos e participa do controle da secreção de insulina. $^{19}$

A isoforma maior da CDK11, p110, interage com fatores de splicing e promove o splicing do RNAm. ${ }^{17}$ 


\subsubsection{Características da CDK12 e da CDK13}

Em 2000, foram identificados cDNAs que codificavam quinases homólogas e de alta massa molecular. ${ }^{20}$ As proteínas que são codificadas por esses cDNAs eram inicialmente chamadas Crkrs (Crk7) e CDC2L5 (Ched), que em 2009 foram renomeadas CDK12 e 13, respectivamente, após a descoberta de sua dependência de ligação a ciclinas para se tornarem ativas. ${ }^{5}$

As CDKs 12 e 13 são proteínas de 1490 e 1512 aminoácidos, respectivamente. O domínio catalítico da CDK12 e da CDK13 consiste de aproximadamente 300 aminoácidos, são 93\% similares e possuem a sequência de aminoácidos conservados PITAIRE ( $\mathrm{P}$ - prolina, I - isoleucina, $\mathrm{T}$ - treonina, A - alanina, R - arginina, E - glutamato). ${ }^{17}$ Possuem resíduos de treonina $\mathrm{e}$ tirosina característicos no início da região de ligação ao ATP, indicando que estes resíduos podem atuar na atividade quinase e uma treonina na região de ativação alça T. ${ }^{18}$

O domínio quinase bastante conservado é cercado por longos domínios $\mathrm{N}$ - e C-terminais de mais de 400 aminoácidos, os quais não possuem uma identidade alta entre si e possuem pouca complexidade, indicando que esta deve ser a região que interage com a ciclina $\mathrm{K}^{21}$

No domínio $N$-terminal existem regiões com sequências PEST (P prolina, E - glutamato, S - serina, T - treonina), conhecidas por participar na renovação (turnover) da enzima, além de motivos ricos em prolina, chamados domínios PPLP (P - prolina, L - leucina), e outros ricos em dipeptídeos de serina (S) e arginina (R); chamados domínios RS (Figura 7). Os domínios PPLP e RS são encontrados em quinases que fosforilam fatores de splicing. Os domínios RS são sequências com 20 e 17 aminoácidos arginina e serina nas CDKs 12 e 13, respectivamente. A CDK13 é uma proteína nuclear de aproximadamente $170 \mathrm{kDa}{ }^{20}$ 
Figura 7 - Representação esquemática da CDK13. O asterisco amarelo representa o domínio quinase. Os domínios ricos em arginina e serina (RS), os domínios ricos em prolina (PRM), ricos em alanina (A) e os ricos em serina (SR) estão indicados em laranja, verde, roxo e violeta, respectivamente.

\section{Cdk13}

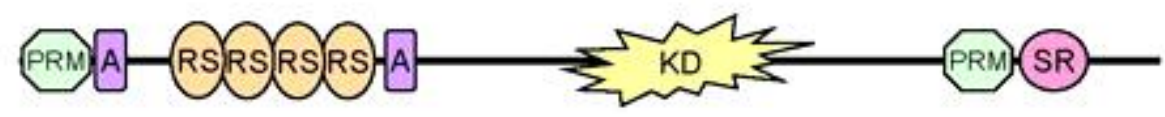

Fonte: KOHOUTEK, J., 2012, p. $4 .{ }^{18}$

\subsubsection{Funções da CDK12 e da CDK13}

\section{Atuação no Splicing:}

Os domínios ricos em dipeptídeos arginina e serina, os domínios RS, estão principalmente presentes em proteínas que regulam o splicing do préRNAm. Os domínios RS dos fatores de splicing, a partir de interações proteína-proteína, mediam a formação da "rede" de proteínas importantes para a seleção do sítio de splicing e a montagem do spliceossomo. A fosforilação dos domínios RS por quinases específicas regula essas interações e fornecem um controle da atividade do splicing. ${ }^{17}$

Foi identificado que a CDK12 e a CDK13 interagem com ciclinas do tipo L. Como a CDK11 também interage com a ciclina $L$ e atua nos eventos de splicing, sugeriu-se que as CDKs 12 e 13 participassem também desses eventos. ${ }^{23,24,25}$ Estudos mostraram que a CDK13 interage diretamente com a proteína p32 associada à ASF/SF2, uma proteína envolvida na regulação do splicing. A superexpressão da CDK13 perturba o splicing e modifica a seleção dos sítios de splicing alternativo in vivo. ${ }^{17}$ A CDK12 fosforila o fator de splicing ASF/SF2 in vitro, sugerindo sua atuação nos eventos de splicing. ${ }^{22}$

Em eucariotos, os RNA mensageiros (RNAm) são sintetizados no núcleo da célula e enquanto continuam lá, podem sofrer processamento póstranscricional. Os pré-RNAm podem conter sequências intervenientes chamadas íntrons que não são expressas e por isso devem ser retiradas antes da expressão no processo de splicing gênico, que ocorre geralmente cotranscricionalmente. ${ }^{3}$ 
Os fatores de splicing, que incluem as proteínas $S R$, recrutam a maquinaria do spliceossomo no sitio de excisão. O spliceossomo é formado pelo pré-RNAm, quatro snRNPs (pequenas ribonucleoproteínas nucleares) e uma variedade de outras proteínas que formam uma entidade altamente dinâmica impelida por ATP que efetua o processo de splicing. Sítios de excisão alternativos podem ser selecionados gerando diferentes sequências de RNAm, no processo chamado splicing alternativo. Éxons (as sequências expressas do RNAm) podem ser conservados ou omitidos, assim como íntrons podem ser excisados ou retidos e as posições de excisão podem ser alteradas formando éxons maiores ou menores. ${ }^{3}$

O splicing alternativo é um dos responsáveis pelas variações proteômicas necessárias para a complexidade dos diferentes órgãos humanos. ${ }^{22}$ Cerca de 38 a $74 \%$ dos genes humanos estão sujeitos ao splicing alternativo. $^{23}$

Manutenção da estabilidade genômica:

Outra função da ciclina K/CDK12 é manter a estabilidade genômica pela regulação da expressão de vários genes de resposta a danos ao DNA, como a expressão de proteínas DDR (proteínas de resposta a danos ao DNA - "DNA damage response") que detectam lesões e mediam os reparos ao DNA. Células sem o complexo ciclina K/CDK12 induzem danos espontâneos ao DNA e são mais sensíveis a uma variedade de agentes que causam danos ao DNA. ${ }^{24}$

Manutenção de células tronco:

As CDKs 12 e 13, assim como a ciclina $\mathrm{K}$ foram altamente expressas em células tronco sendo que a expressão diminuiu com a diferenciação celular, portanto, possuem também a função de impedir a diferenciação das células tronco. $^{21}$

\section{Controle transcricional:}

Estudos mostraram que as CDKs 12 e 13 são também CTD (domínio carboxi-terminal) quinases. ${ }^{25}$ Foi observado que CDK12 fosforila o CTD da RNA polimerase II in vivo e in vitro, e a CDK13 fosforila in vitro, ${ }^{18}$ sugerindo sua 
atuação nos eventos de transcrição. ${ }^{22}$ Qualquer processo ou evento dependente da fosforilação do CTD da RNAPII (RNA polimerase II) na etapa de elongação da transcrição geralmente é afetada em células deficientes em CDK12 e em CDK13. ${ }^{25,26}$

A transcrição é a primeira e a etapa mais regulada na expressão de genes eucarióticos. ${ }^{27}$

Os domínios RS das proteínas que atuam na transcrição servem de sítios de acoplamento para a RNAPII, a qual possui um CTD não-estruturado, na sua subunidade maior, com 52 repetições do heptapeptídeo conservado: Tirosina1, Serina2, Prolina3, Treonina4, Serina5, Prolina6 e Serina7 (Y1S2P3T4S5P6S7), do qual as serinas 2, 5 e 7, a treonina e a tirosina podem ser fosforiladas, ${ }^{18,26,28}$ A função do CTD é coordenar a transcrição com o processamento do RNA mensageiro, ele serve como um andaime para a ligação seletiva de fatores nucleares. A especificidade de ligação do CTD para fatores particulares é determinada pelo seu estado de fosforilação que varia durante o ciclo de transcrição. ${ }^{25}$

Várias CDKs e fosfatases regulam o estado de fosforilação do CTD e a subsequente ligação aos fatores de transcrição e de processamento do RNAm. ${ }^{18}$

O ciclo de transcrição pode ser dividido em três fases principais: iniciação, quando a RNAPII é recrutada pelo promotor para iniciar a síntese do RNA; elongação, durante a qual a polimerase estende o transcrito de RNA; e a terminação, quando a polimerase e o transcrito se separam do molde de DNA. ${ }^{27}$

Porém, mais detalhadamente, o processo consiste de várias etapas, incluindo formação do complexo de pré-iniciação, iniciação, pausa, liberação do promotor, elongação produtiva e terminação. ${ }^{18}$

A RNAPII não fosforilada é recrutada ao promotor para a montagem do complexo de pré-iniciação. A fosforilação da serina 5 é uma marca da RNAPII em pausa e é mediada pela CDK7, uma subunidade do fator TFIIH, levando a iniciação e liberação do promotor. ${ }^{26}$ Assim, a serina 5 fosforilada predomina na iniciação. ${ }^{28}$ Para permitir a elongação produtiva, a quinase P-TEFb (da qual a CDK9 faz parte) e as CDKs 12 e 13, fosforilam os resíduos de Serina 2 do 
CTD, entre outros alvos. Essa fosforilação modifica o ambiente dos fatores associados à RNAPII para um ambiente favorável à transcrição processiva.

Então a serina 2 fosforilada aumenta durante a elongação, resultando no CTD duplamente fosforilado no centro do gene. ${ }^{27,28,30}$ Enquanto a elongação do transcrito ocorre, as serinas 5 são desfosforiladas e a fosforilação da serina 2 acumula até a saturação. Portanto, na direção 3 ' do gene, a serina 5 fosforilada começa a diminuir, deixando a polimerase fosforilada apenas na serina $2 .{ }^{28} \mathrm{~A}$ terminação resulta da desfosforilação da serina 2 do CTD, que faz a RNAPII pronta para um novo ciclo de transcrição. ${ }^{18}$ A Figura 8 apresenta um esquema da transcrição.

Figura 8 - Representação das primeiras três etapas principais da transcrição: iniciação, pausa e elongação. Na iniciação, o TFIIH fosforila a serina 5 do CTD da RNAPII. Na etapa de pausa, o P-TEFb fosforila a serina 2 do CTD levando à etapa de elongação. Fosfatases retiram os fosfatos de ambas serinas para que a RNAPII possa entrar em um novo ciclo de transcrição.

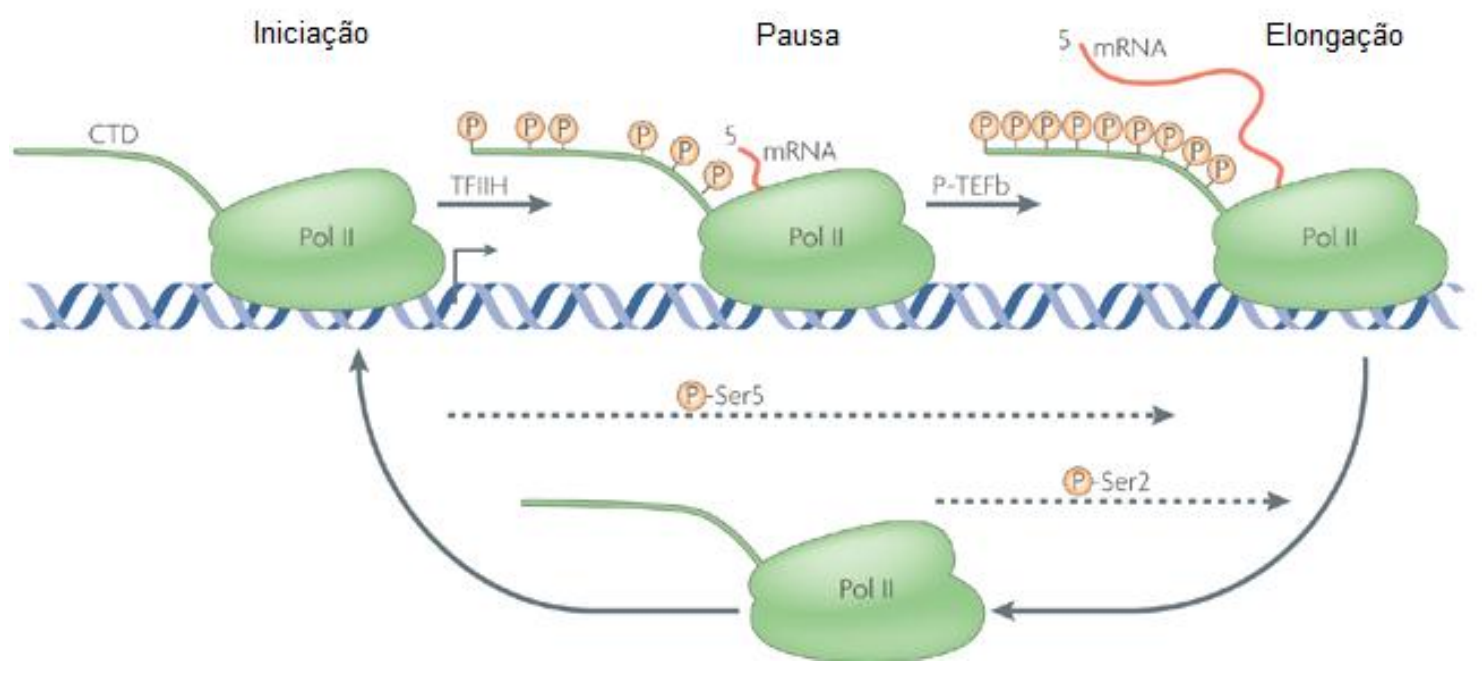

Fonte: Adaptado de COLE, M. D., 2008. p. $812 .^{26}$

As funções da CDK13 incluem também participação no controle da diferenciação e apoptose..$^{20,31}$ 


\subsubsection{Doenças relacionadas à CDK12 e à CDK13}

HIV:

Foi observado que a CDK13 interage com a proteína Tat do vírus HIV in vivo e in vitro. A CDK13 aumenta o splicing do RNAm do HIV e atua como um possível fator de restrição, no qual sua superexpressão diminui a produção de proteínas virais e consequentemente suprime a produção viral. O silenciamento da CDK13 leva a um significante aumento na produção do vírus.

A CDK13 media o splicing pela fosforilação do ASF/SF2 (o fator de splicing). Durante o início da infecção, a CDK13 induz o splicing do RNAm do HIV pela fosforilação do ASF/SF2. Uma vez que a proteína viral Tat se acumula nas células infectadas, ela recruta a CDK13 juntamente com a proteína p32 formando um complexo inibitório, no qual a $\operatorname{CDK13}$ não é mais capaz de fosforilar o ASF/SF2, e então o splicing é inibido. A inibição do splicing é característica de fases mais tardias de infecção, onde o RNAm que codifica proteínas estruturais predomina. A CDK13 atua como um fator de restrição que impede a replicação do vírus, possivelmente mediando o splicing excessivo. Ao recrutar a CDK13 no complexo inibitório, a Tat parece estar resgatando o vírus assegurando sua replicação (Figura 9). Ainda não se sabe se a Tat se liga ao domínio catalítico da CDK13 impedindo sua atividade ou se a endereça para degradação. São conhecidos vários inibidores e ativadores de CDK que podem inibir ou ativar a CDK13, e uma possibilidade seria usar essas drogas para diminuir a replicação do vírus pelo aumento da atividade da CDK $13 .{ }^{30}$ 
Figura 9 - llustração do efeito do complexo Tat-p32-CDK13 na regulação do splicing no HIV. Na ausência do complexo Tat-p32, a CDK13 fosforila a ASF/SF2, necessária para um splicing eficiente. Em estágios mais avançados da infecção, quando a Tat se acumula, a Tat-p32 recruta a CDK13, impedindo a fosforilação de ASF/SF2.

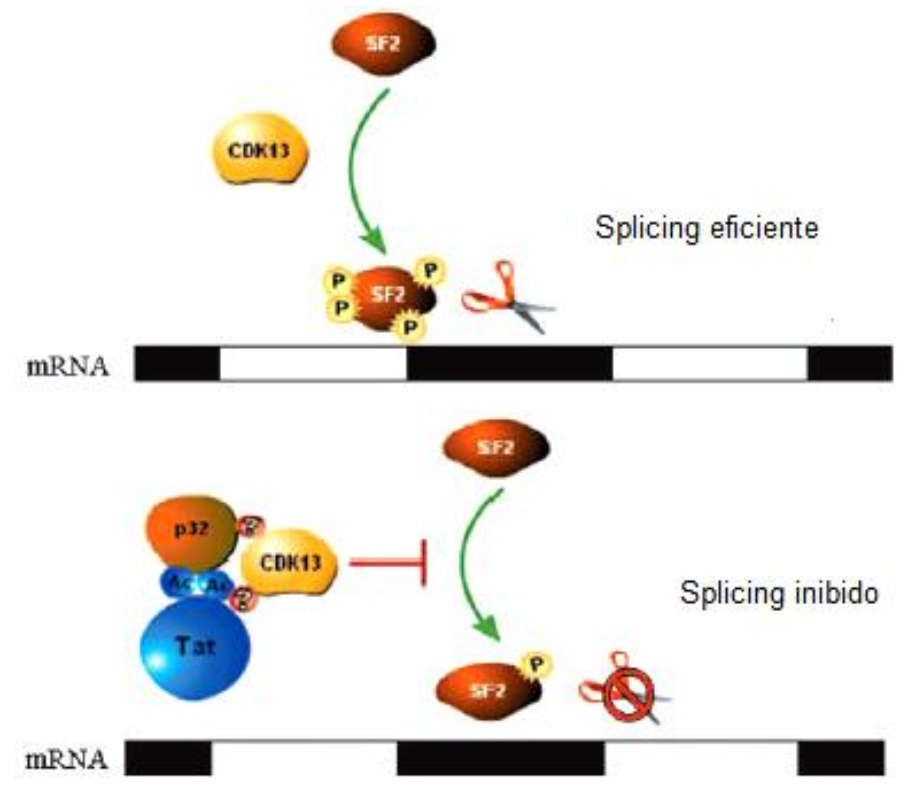

Fonte: Adaptado de BERRO, R., 2008, p. 7165.

Doenças associadas à desregulação do splicing:

Mutações que afetam os padrões de splicing são algumas das causas de alguns cânceres e doenças degenerativas. ${ }^{22}$ Aproximadamente $15 \%$ das doenças associadas a mutações nos genes humanos envolvem a desregulação do splicing alternativo, portanto estudos sobre as vias e proteínas que atuam nos eventos de splicing, como as CDKs 12 e 13, podem ajudar a entender os processos celulares e possibilitar novas formas de controlar doenças humanas. ${ }^{22,23}$

Doenças associadas à desregulação da fosforilação do CTD:

A fosforilação incorreta do CTD foi relacionada a várias doenças como hipertrofia cardíaca e leucemia. Alta concentração de CDK13 foi encontrada em pacientes com anemia associada à trombocitose, doença causada pela ineficiente hematopoese (produção de sangue). Portanto, as quinases que fosforilam o CTD se tornam alvos para o desenvolvimento de pequenos inibidores químicos como agentes terapêuticos. ${ }^{18}$ 
Influenza:

A CDK13 é necessária também para a replicação do vírus Influenza. $O$ silenciamento do DNA referente à CDK13 leva à diminuição da replicação do vírus. Estudos sobre novos alvos, como a CDK13, para o desenvolvimento de drogas antivirais vêm sendo realizados por causa da resistência que o vírus adquiriu a muitas drogas e pela dificuldade no desenvolvimento de vacinas, para os diferentes tipos de vírus Influenza, os quais possuem alta taxa de mutação. $^{32}$

\section{Câncer:}

Foi descoberto que a CDK12 contribui para a estabilidade genômica, a qual é crucial para a viabilidade da célula e prevenção de doenças como câncer. A CDK12 regula a expressão de vários genes relacionados ao câncer, e sua desregulação foi identificada em vários tipos de câncer, como de ovário, mama e gástrico. ${ }^{18}$

A amplificação dos genes (aumento no número de genes transcritos e expressos) da CDK13 foi identificada em vários tipos de cânceres. O número de cópias do gene da CDK13 é significantemente aumentado em pacientes com HCC (câncer hepatocelular) e é comum em câncer de cólon e reto. Linhagens de células com alta concentração da CDK13 foram suscetíveis ao tratamento com tamoxifen (Figura 10), sugerindo que pode ser um alvo terapêutico para tratamento de câncer, e indicando os efeitos oncogênicos do gene da CDK13. ${ }^{33}$

Figura 10 - Fórmula estrutural do Tamoxifen.

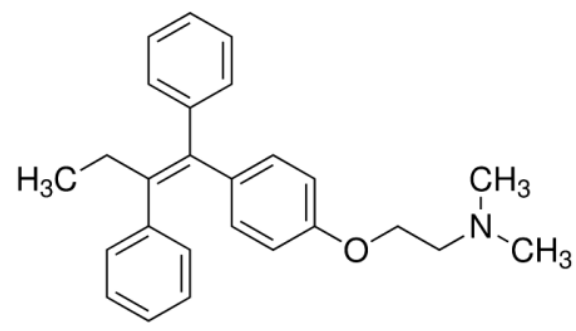

Fonte: SIGMA-ALDRICH, Tamoxifen, $2013 .^{34}$ 


\subsection{CDKs como alvos para tratamento de câncer}

Os componentes da maquinaria do ciclo celular estão frequentemente alterados em câncer humano e os principais componentes são as quinases dependentes de ciclina. Em células malignas, ocorre superexpressão de ciclinas e diminuição da expressão dos inibidores de CDKs, gerando a desregulação na atividade das CDKs, promovendo células com vantagem em crescimento. $^{12}$

Estratégias com o ciclo celular como alvo para tratamento de cânceres incluem inibidores químicos da atividade catalítica de CDKs, inibição das interações entre as ciclinas e CDKs, diminuição da expressão de CDKs, promoção da degradação de ciclinas pelo aumento de fosforilação, e restauração da função endógena dos inibidores de CDKs. ${ }^{35}$

A inibição da atividade das CDKs tem sido a maior função dos compostos em estudo com o objetivo de diminuir a proliferação de células tumorais. As células tumorais são dependentes dos diferentes complexos ciclinas/CDKs em sua fase de proliferação e, portanto, podem ser inibidas (deixar de se proliferar e entrar na fase de senescência, ou ser levada a apoptose) pela inibição da atividade de CDKs específicas para cada tipo de tumor. $^{10}$

Já existem aproximadamente 30 compostos em estudo como inibidores de CDKs e um progresso considerável na identificação destes compostos vem ocorrendo desde $2003 .^{18} \mathrm{~A}$ primeira geração dos inibidores de CDKs tinha pouca especificidade, como o flavopiridol (Figura 11), o qual inibe CDKs e também muitos outros alvos. A segunda geração de inibidores são mais seletivos, sendo desenvolvidos para CDKs específicas, como a roscovitina (Figura 11). ${ }^{35}$ 
Figura 11 - Fórmulas estruturais do flavopiridol e roscovitina.<smiles>CN1CC[C@](O)(c2c(O)cc(O)c3c(=O)cc(-c4ccccc4Cl)oc23)C[C@H]1O</smiles>

Flavopiridol

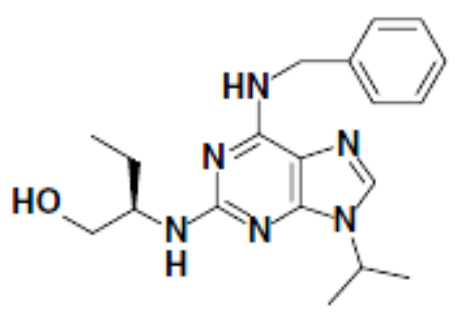

Roscovitina

Fonte: Adaptado de BENSON, C., 2005, p. $9 .{ }^{35}$

O flavopiridol tem como alvos CDK1, 2, 4, 6, 7 e 9, porém a concentração utilizada para inibir a CDK9 não foi o suficiente para inibir as CDKs 12 e 13. ${ }^{18,35}$ O composto está em ensaios clínicos da fase II, principalmente como inibidor da CDK9. A administração de flavopiridol tem efeitos profundos na transcrição e resulta na diminuição de RNA mensageiros que codificam fatores de transcrição, reguladores do ciclo celular, quinases e proteínas que mediam a resposta antiapoptótica; ${ }^{36}$ modificando o grau de proliferação celular. ${ }^{37,38} \mathrm{O}$ composto age de maneira competitiva, se ligando ao bolsão de ligação ao ATP pelo anel benzopirânico que ocupa a mesma região que o anel purina do ATP. 4

A roscovitina é um inibidor altamente seletivo, o que diminui sua toxicidade. ${ }^{35}$ É um potente inibidor da ciclina E/CDK2, ciclina H/CDK7, e ciclina T/CDK9. Estudos sobre a ligação do inibidor à CDK2 mostra que sua porção purina se liga à mesma região de ligação da adenina do ATP ao bolsão de ligação da CDK, atuando de modo competitivo. O grupo benzil do anel do inibidor permite que ele tenha contato com a enzima. ${ }^{13}$

Apesar do sucesso de muitos compostos na terapia contra o câncer, muitos não são capazes de erradicar cânceres sólidos e de sangue e muitas vezes não são seletivos o bastante, sendo tóxico para as células saudáveis. ${ }^{4}$

Outras dificuldades são as diferenças morfológicas e fisiológicas entre os vários cânceres, a heterogeneidade molecular dentro da mesma população, a instabilidade genômica das células cancerosas e o desenvolvimento de 
resistência a múltiplas drogas. ${ }^{4}$ Portanto, existe a necessidade de identificar novos alvos, como por exemplo, as CDKs, para a terapia contra câncer e o desenvolvimento de novas drogas, seletivamente tóxicas às células tumorais. ${ }^{35}$

Apenas alguns substratos fisiológicos das CDKs foram identificados, e faltam detalhes dos mecanismos pelos quais as CDKs regulam as transições das fases do ciclo celular, ${ }^{15}$ por isso mais estudos sobre a estrutura, função e atividade das CDKs se tornam importantes, e a partir dos resultados desses estudos cada vez mais se ficará próximo do desenvolvimento de compostos seletivamente tóxicos às células tumorais e do entendimento da interação destas proteínas com outras, presentes nas células.

\subsection{Câncer}

\subsubsection{Dados estatísticos}

O câncer é a principal causa de morte em países desenvolvidos economicamente e a segunda causa de morte em países em desenvolvimento. ${ }^{39}$

A Tabela 1 mostra dados estatísticos do número de mortes e de casos de câncer no ano de 2008 mundialmente; as estimativas para o ano de 2014 no Brasil; e para o ano de 2030 mundialmente.

Tabela 1 - Dados de 2008 e estimativas para o ano de 2030 mundialmente e estimativas para 2014 no Brasil, dos números de mortes e casos de câncer.

\begin{tabular}{l|l|l}
\hline \multicolumn{1}{c|}{ Dados de 2008 } & $\begin{array}{l}\text { Estimativas feitas em } \\
\mathbf{2 0 0 7} \text { para o ano de 2030 } \\
\text { mundialmente }\end{array}$ & \multicolumn{1}{c}{$\begin{array}{c}\text { Estimativas para 2014 no } \\
\text { Brasil }\end{array}$} \\
\hline $\begin{array}{l}\text { O câncer foi a causa de 7,6 } \\
\text { milhões de mortes (13\% do } \\
\text { total de mortes } \\
\text { mundialmente). }\end{array}$ & $\begin{array}{l}\text { As mortes devem } \\
\text { aumentar 45\%: de 7,9 } \\
\text { para 11,5 milhões. }\end{array}$ & $\begin{array}{l}\text { Estima-se } 580 \text { mil novos } \\
\text { casos no Brasil. }\end{array}$ \\
$\begin{array}{l}\text { Mais que AIDS, malária e } \\
\text { tuberculose juntas. }\end{array}$ & $\begin{array}{l}\text { O número de casos deve } \\
\text { aumentar de 11,3 para } \\
15,5 \text { milhões. }\end{array}$ & $\begin{array}{l}\text { Os principais tipos deverão } \\
\text { ser: } \\
\text { Pele não melanoma, } \\
\text { Próstata, } \\
\text { Mama, }\end{array}$ \\
$\begin{array}{l}\text { Total de 12,7 milhões de } \\
\text { casos foram detectados. }{ }^{41}\end{array}$ & $\begin{array}{l}\text { Principais motivos: } \\
\text { envelhecimento, e reto, } \\
\text { aumento da população. }{ }^{40}\end{array}$ & $\begin{array}{l}\text { Pulmão, } \\
\text { Estômago. }{ }^{45}\end{array}$ \\
\hline
\end{tabular}


A Tabela 2 mostra alguns dados sobre os tipos de cânceres de maior incidência e mais letais mundialmente.

Tabela 2 - Os tipos de cânceres que mais causaram mortes em 2008, os tipos mais comuns, e os mais letais.

\begin{tabular}{l|l|l}
\hline \multicolumn{1}{c|}{ Maiores causadores de mortes em } & Mais comuns & \multicolumn{2}{c}{ Mais letais } \\
\hline - Pulmão $(1,37$ milhões de & $\begin{array}{l}\text { - Pulmão } \\
\text { mortes })\end{array}$ & $\begin{array}{l}\text { - Mama } \\
\text { - Fúgão }\end{array}$ \\
- Estômago $(736.000)$ & & Cólon e reto \\
- Fígado $(695.000)$ & & \\
- Cólon e reto $(608,000)$ & & \\
- Mama $(458,000)$ & & \\
- Útero $(275,000)^{42,44}$ & & \\
\hline
\end{tabular}

Sem contar o câncer de pele não melanoma, entre os homens, o câncer de próstata é o mais incidente no Brasil, seguido do de pulmão e cólon e reto. $^{39,45}$ Já entre as mulheres, o de mama é o mais frequente, seguido do de cólon e reto e de colo do útero. O câncer de fígado é o quinto tipo mais frequentemente diagnosticado mundialmente e o segundo mais frequente em causa de mortes por câncer. ${ }^{39}$

Os dados estatísticos mostram que os cânceres de fígado e cólon e reto, relacionados ao descontrole da atividade das CDKs 12 e 13 têm alta incidência, destacando a importância de estudos sobre estas proteínas como alvos para desenvolvimento de inibidores para tratamento de câncer.

A prevenção, detecção precoce e tratamento constituem a estratégia mais completa para o controle do câncer. ${ }^{47}$

O World Health Organization (WHO) e a International Agency for Research on Cancer (IARC) lançaram em 2008 os planos de ação para o controle de câncer, por causa do aumento do número de casos da doença a cada ano; do impacto social e econômico que causa (o Ministério da Saúde investiu 2,1 bilhões de reais na área de oncologia no Brasil, um crescimento de $26 \%$ em relação a $2010^{45}$ ) e por que mais da metade dos países não está preparada para prevenir e tratar a doença.$^{39,46}$ 


\subsubsection{Células cancerosas: características e desenvolvimento}

As células cancerosas possuem duas propriedades hereditárias que thes conferem sua periculosidade: são capazes de se reproduzirem desobedecendo aos limites de divisão celular normais e têm a capacidade de invadir e colonizar regiões destinadas a outras células, em um processo chamado metástase. Compartilham também outras características como capacidade de fuga da apotose, por serem resistentes a sinais que programam a morte celular e apoptose; possuem alto potencial de replicação e alta proliferação celular por conseguirem se multiplicar na ausência de fatores de crescimento; e angiogênese autossustentável. Entretanto, o câncer é uma doença extremamente heterogênea e complexa, pois os tumores possuem diferentes comportamentos dependendo do tecido e envolvem a desregulação das vias de transdução de sinal. ${ }^{2,48,49}$

Quando a célula anormal cresce aumentando sua massa e se prolifera, dividindo-se descontroladamente, dá origem ao tumor, que pode ser benigno, caso não sejam células invasivas; ou maligno (chamado de câncer), quando as células são capazes de invadir tecidos adjacentes. As células malignas podem se desprender do tecido, atingir a corrente sanguínea e formar tumores secundários, as metástases. ${ }^{2}$

A progressão do tumor, transformação de uma célula normal para uma maligna, geralmente leva muitos anos e segue o processo Darwiniano de evolução. As células somáticas sofrem mutações e alterações epigenéticas (alteração no padrão de expressão sem mudança na sequência do DNA). Mutações em 291 genes estão relacionadas ao aparecimento de tumores, e representam $1 \%$ do genoma humano. As mutações e alterações epigenéticas ativam oncogenes e/ou levam à perda de função dos genes supressores de tumor estimulando a proliferação e simultaneamente bloqueando a morte das células que então passam por seleção natural. ${ }^{48,50,51}$

\section{Oncogenes:}

Os proto-oncogenes são genes em seu estado normal que codificam proteínas que controlam o ciclo de divisão celular. Quando sofrem alterações e 
se tornam os oncogenes, a proteína anormal resultante possui uma atividade muita alta e contribui para o crescimento do tumor. A célula do tumor ao invés de permanecer na fase $\mathrm{GO}$, como normalmente faria, continua passando pelas fases subsequentes do ciclo, levando a uma divisão celular descontrolada. Os oncogenes também podem resgatar células programadas para morte celular. Foram identificados vários oncogenes como, por exemplo, cmyc, ras, E2F, vjun, CDKs e ciclinas. ${ }^{48,53,54}$

Os proto-oncogenes são convertidos a oncogenes por mutações ou translocações cromossomais, quando partes de cromossomos rompidos se unem novamente de forma desordenada, levando a produção de proteínas contendo a região $\mathrm{N}$-terminal de uma proteína ligada à região $\mathrm{C}$-terminal de outra, ou levando a uma expressão com regulação alterada da proteína, ou o proto-oncogene pode existir em múltiplas cópias na célula, resultando numa expressão amplificada. ${ }^{52,55,56}$

Genes supressores de tumor:

Os genes supressores de tumor codificam proteínas que normalmente atuam na restrição do crescimento celular e divisão ou promovem a morte celular programada (apoptose). Alterações genéticas como mutações ou translocações podem levar a produção de proteínas regulatórias inativadas incapazes de atuar na inibição da proliferação celular. ${ }^{52}$

As células cancerosas poderiam ser eliminadas tendo como alvo a lesão oncogênica que confere a vantagem proliferativa, os mecanismos de apoptose desregulados nessas células, e os danos causados aos genes supressores de tumor. Seria possível focar nas proteínas resultantes dos oncogenes e de posse de suas estruturas e funções, poderia se criar novos inibidores mais seletivos podendo levar a regressão do tumor, até mesmo de tumores malignos. ${ }^{48,57}$ 


\section{OBJETIVOS}

Os objetivos gerais do projeto são clonar, expressar em sistema heterólogo (Escherichia coli) e purificar, utilizando métodos cromatográficos, a proteína CDK13 humana.

Os objetivos específicos são:

- Amplificar o DNA correspondente à proteína CDK13 humana a partir de biblioteca de cDNA de cérebro fetal humano;

- Clonar o DNA em vetor de propagação;

- Subclonar o DNA em vetor de expressão;

- Expressar a proteína CDK13 em sistema heterólogo (Escherichia coli);

- Purificar a proteína por cromatografia de afinidade ao níquel.

Tal estudo irá contribuir para a obtenção da proteína CDK13 humana, a qual poderá ser utilizada em experimentos que ajudem a entender a relação entre a estrutura e a função da CDK13 e sua relação com os eventos de ciclo de divisão celular e de splicing alternativo dos quais ela participa. 


\section{MATERIAIS E MÉTODOS}

O processo de obtenção da CDK13 pode ser dividido em três etapas principais: clonagem, expressão e purificação da enzima, as quais foram baseadas no protocolo estabelecido para a CDK9. ${ }^{60}$

A Figura 12 apresenta um diagrama com os experimentos realizados nesse estudo.

Figura 12 - Diagrama das etapas realizadas para obtenção da proteína CDK13 humana.

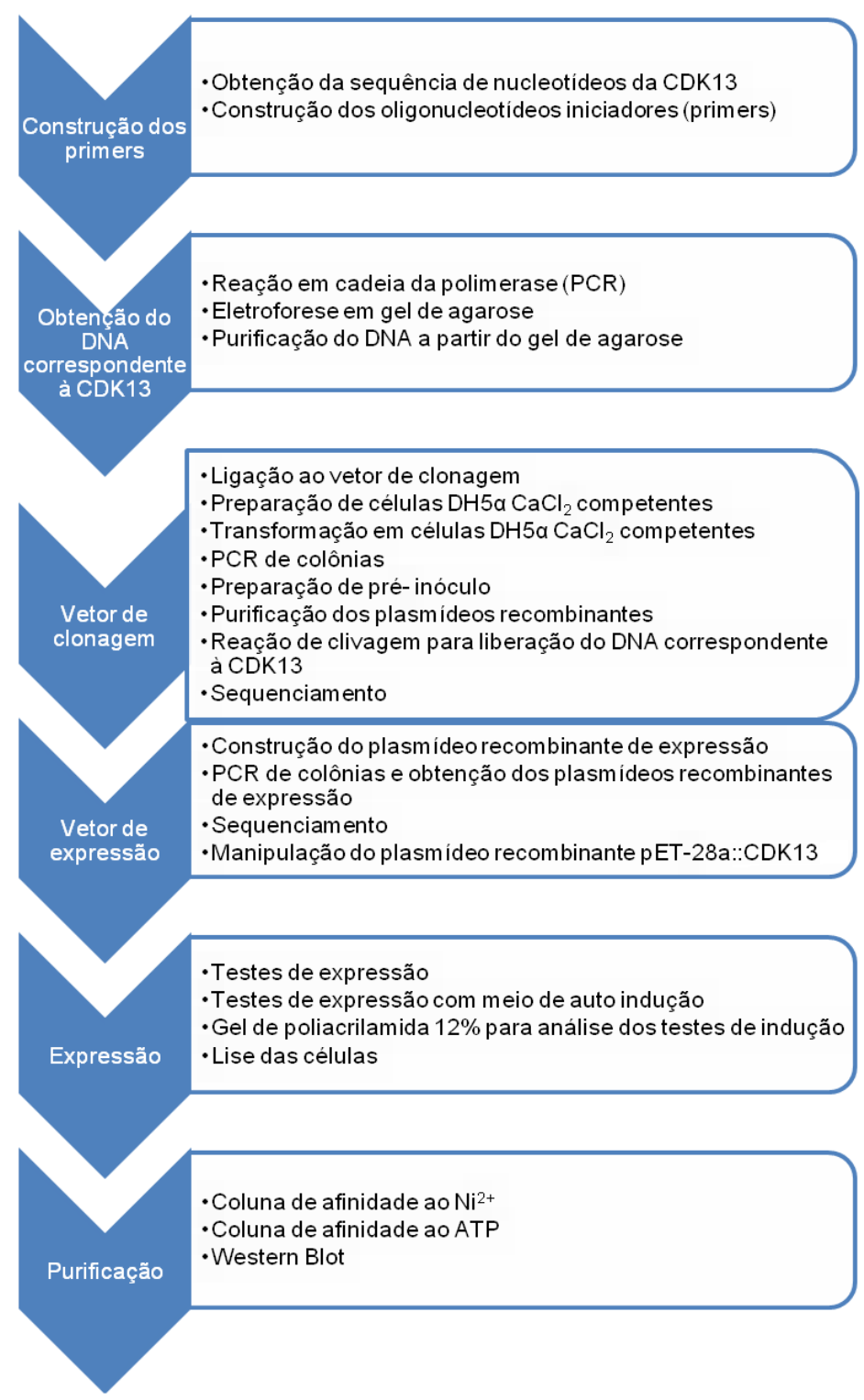

Fonte: Autoria própria. 
Modificações dos protocolos foram realizadas quando necessário. Antes da clonagem, as etapas a seguir foram cumpridas.

\subsection{Obtenção da sequência de nucleotídeos da CDK13}

A sequência de nucleotídeos correspondente à CDK13 foi identificada a partir da sequência de aminoácidos da proteína em pesquisa no banco de dados GenBank (http://www.ncbi.nlm.nih.gov/genbank/GenbankSearch.html) do NCBI (National Center of Biotechnology Information), (isoforma 1 da proteína CDK13, código NP_003709.3) e sua aplicação na ferramenta de bioinformática BLASTn (Basic Local Alignment Search Tool) (http://www.ncbi.nlm.nih.gov/), que transforma a sequência de aminoácidos na correspondente sequência de nucleotídeos.

\subsection{Construção dos oligonucleotídeos iniciadores (primers)}

A sequência de DNA correspondente à CDK13 identificada no banco de dados GenBank foi utilizada para construção dos primers. Foram introduzidos nestes primers, sítios para enzimas de restrição na região 5' do códon de iniciação (sítio para a enzima Ndel) e na região 3' do códon de terminação (sítio para a enzima BamHI). A escolha das enzimas de restrição foi feita após análise da sequência da CDK13 utilizando-se a ferramenta Web Cutter (http://rna.lundberg.gu.se/cutter2/), que apresenta quais enzimas não clivam a sequência de nucleotídeos correspondente à proteína CDK13 e então poderiam ser adicionadas aos primers, e a ferramenta Gene Runner (http://www.generunner.net/) que calcula a temperatura de anelamento (Tm) do primer, a porcentagem dos nucleotídeos guanina e citosina, e possibilidade de formação de hairpins (interação entre os nucleotídeos da própria sequência do primer que dificultam as reações de PCR). As sequências dos primers se encontram na Tabela 3. 
Tabela 3 - Sequências dos primers utilizados na amplificação do DNA referente à CDK13.

\begin{tabular}{c|c|c}
\hline Primer & $\begin{array}{c}\text { Enzimas } \\
\text { de } \\
\text { Restrição }\end{array}$ & Sequências dos primers 5'-3' \\
\hline Cdk13_Fw (5') & $\underline{\text { Ndel }}$ & AGA $\underline{\text { CAT ATG CTG CCT GAA GAT AAA GAA GC }}$ \\
\hline Cdk13_Rv (3') & BamHI & ACA GGA TCC TCA GTA TGG TAA CCC TCT G \\
\hline
\end{tabular}

Os primers 5' (forward - Fw) e 3' (reverse - Rv) liofilizados foram diluídos a uma concentração de $100 \mu \mathrm{M}$ para estoque, e a partir deste foram diluídos para $10 \mu \mathrm{M}$, a concentração utilizada na PCR.

Em seguida, foi realizada a clonagem do DNA referente à CDK13 que compreende as etapas descritas no item 3.3.

\subsection{Clonagem e Subclonagem}

\subsubsection{Reação em cadeia da polimerase (PCR)}

A PCR amplifica o DNA de interesse, no caso, o da CDK13. Foi utilizado como molde a biblioteca de cDNA de cérebro fetal humano (CFH) CLONTECH (200ng/ $\mu \mathrm{L})$, cedido pela Profa. Dra. Ana Paula Ulian de Araújo do grupo de Biofísica Molecular "Sérgio Mascarenhas" do Instituto de Física de São Carlos.

As concentrações dos reagentes da reação foram baseadas nas instruções do fabricante da enzima polimerase que foi utilizada, a enzima de alta fidelidade Phusion High-Fidelity PCR Master Mix (Finnzymes), DMSO (dimetilsulfóxido), o qual ajuda na separação da fita dupla de DNA da CDK13 que é rica em nucleotídeos citosina e guanina, desoxirribonucleotídeos, e os primers. O volume final de cada reação foi de $50 \mu \mathrm{L}$, o qual foi dividido em 5 alíquotas de $10 \mu \mathrm{L}$ e cada qual foi submetida a uma diferente temperatura de anelamento.

As reações de amplificação foram realizadas no equipamento termociclador MyCycler Thermal Cycler (Bio-Rad), o programa utilizado no equipamento consistiu de ciclos de amplificação, os quais são divididos em 3 
etapas: desnaturação (as duas fitas do DNA são separadas por aquecimento), anelamento (o resfriamento possibilita o anelamento dos primers às fitas do DNA) e extensão (aquecimento até a temperatura ótima da enzima polimerase que sintetiza as novas fitas de DNA na direção 5' para 3', a partir da extremidade 3 ' do primer). A cada ciclo a quantidade de DNA duplica. ${ }^{58,59}$

As Tabelas 4 e 5 apresentam as quantidades de reagentes e parâmetros da reação de PCR utilizados.

Tabela 4 - Reação de PCR para a amplificação do DNA referente à CDK13.

\begin{tabular}{c|c}
\hline Reagentes & Volume $(\mu \mathrm{L})$ \\
\hline $2 \times$ Phusion Master Mix (Finnzymes) & 25 \\
\hline Primer Forward da CDK13 $(10 \mu \mathrm{M})$ & 2 \\
\hline Primer Reverse da CDK13 $(10 \mu \mathrm{M})$ & 2 \\
\hline cDNA CFH $(200 \mathrm{ng} / \mu \mathrm{L})$ & 1 \\
\hline DMSO & 1,5 \\
\hline $\mathrm{H}_{2} \mathrm{O}$ & 18,5 \\
\hline Total & 50 \\
\hline
\end{tabular}

Tabela 5 - Programa do termociclador utilizado para a amplificação do DNA referente à CDK13.

\begin{tabular}{c|c|c}
\hline Temperatura $\left({ }^{\circ} \mathbf{C}\right)$ & Tempo & Etapa \\
\hline 98 & 30 segundos & Desnaturação \\
\hline 98 & 10 segundos & Desnaturação \\
\hline$*$ & 30 segundos & Anelamento \\
\hline 72 & 45 segundos & Extensão \\
\hline 72 & 10 minutos & Extensão final \\
\hline 4 & $\infty$ & \\
\hline
\end{tabular}

* Gradiente de temperatura de 53 a $60^{\circ} \mathrm{C}$

A técnica de eletroforese em gel de agarose foi utilizada para análise dos produtos das reações de PCR. 


\subsubsection{Eletroforese em gel de agarose}

Foram utilizados géis de agarose de $0,8 \%$ em tampão TAE $\left(40 \mathrm{mmolL}^{-1}\right.$ de Tris-acetato $\mathrm{pH} 8,0 ; 1 \mathrm{mmolL}^{-1}$ EDTA - ácido etilenodiaminotetracético) para a migração diferencial dos fragmentos de DNA.

Foram aplicados $5 \mu \mathrm{L}$ de cada produto de reação de PCR juntamente com o tampão Loading $6 x$ no gel, o qual foi submetido a uma diferença de potencial de 110 Volts e corrente elétrica de $100 \mathrm{~mA}$ por aproximadamente 30 minutos.

A eletroforese se baseia no movimento de partículas carregadas, no caso os fragmentos de DNA, que possuem carga negativa em $\mathrm{pH}$ neutro por causa dos grupos fosfato dos nucleotídeos, em um campo elétrico, que é gerado por dois eletrodos. A carga negativa dos fragmentos de DNA os leva a migrar em direção ao eletrodo positivo. A mobilidade do DNA é geralmente inversamente proporcional ao logaritmo do número de pares de bases, sendo que o movimento de uma partícula carregada no campo elétrico depende da sua razão carga/massa. O gel de agarose é um exemplo de gel polimérico, a agarose é um polissacarídeo obtido a partir do ágar, que forma uma matriz inerte, com padrão entrecruzado, com poros pelos quais o DNA se move. ${ }^{58,59}$

O gel foi incubado em solução de brometo de etídio $0,25 \mu \mathrm{g} / \mu \mathrm{L}$ por 15 minutos, necessário para a visualização dos fragmentos de DNA, por meio de luz ultravioleta (UV) no equipamento Bio-Imaging Systems MiniBIS Pro acoplado a um computador. As moléculas de brometo de etídio possuem uma porção planar que se intercala entre as bases nitrogenadas dos nucleotídeos do DNA, e fluorescem quando expostas à luz UV. ${ }^{61}$

Os padrões GeneRuler 1Kb DNA Ladder (Fermentas) ou Quick Load 2Log DNA Ladder 0,1-10,0Kb (New England BioLabs), foram aplicados no gel de agarose ao lado das alíquotas dos produtos de reações de PCR, para a comparação entre as bandas de fragmentos de DNA geradas pelas alíquotas, com as bandas do padrão. Assim foi possível estimar a concentração do DNA por comparação de intensidade das bandas e o tamanho do fragmento por comparação com a posição das bandas do marcador. 


\subsubsection{Purificação do DNA a partir do gel de agarose}

Após a determinação dos melhores parâmetros para a reação de PCR, foi feita uma reação de $50 \mu \mathrm{L}$, e todo o produto desta reação foi aplicado no gel de agarose a fim de isolá-lo. A banda obtida no gel, correspondente ao fragmento de DNA de interesse, o da CDK13, foi extraído do gel utilizando-se o kit QI Aquick Gel Extraction (QIAGEM), baseando-se no protocolo indicado neste. A concentração do DNA purificado foi determinada pelo equipamento Thermo Scientific NanoDrop ${ }^{T M} 1000$ Spectrophotometer, do Laboratório de Biologia Molecular do Grupo de Cristalografia (IFSC), o qual requer $1-2 \mu \mathrm{L}$ de amostra na quantificação.

\subsubsection{Ligação ao vetor de clonagem}

O DNA correspondente à CDK13 purificado a partir do gel de agarose foi ligado ao vetor de clonagem pCR-Blunt do kit Zero Blunt PCR Cloning (Invitrogen). Este vetor foi escolhido, pois não possui timinas ou adeninas nas suas extremidades, e o DNA amplificado pela enzima Phusion High-Fidelity PCR Master Mix (Finnzymes) apresenta extremidades cegas.

Foram feitas reações com diferentes proporções inserto:vetor até que a reação de ligação fosse eficiente, baseando-se no protocolo de utilização do vetor. Para se determinar a quantidade de DNA (inserto) a ser utilizada para uma proporção de inserto:vetor (10:1), considerando-se a concentração de 25 ng de vetor, utilizou-se a seguinte equação:

$$
\mathrm{x} \text { ng inserto }=\frac{10 \mathrm{x} \text { Y pbprodutoPCR } \mathrm{x} 25 \mathrm{ng} \mathrm{pCR}-\text { Blunt }}{3500 \mathrm{pbpCR}-\text { Blunt }}
$$

Cada reação de ligação foi feita para um volume final de $10 \mu$, utilizando a enzima T4 DNA ligase 40U/ $\mu \mathrm{L}$ (Fermentas), tampão 10x com ATP, e DNA referente à $\mathrm{CDK} 13$. A reação foi incubada a $16^{\circ} \mathrm{C}$ por 1 hora. 


\subsubsection{Preparação de células $\mathrm{DH} 5 \alpha \mathrm{CaCl}_{2}$ competentes}

Células da cepa DH5a foram inoculadas em ambiente estéril (fluxo laminar ESCO) em uma Placa de Petri contendo meio LB sólido (meio LuriaBertani ao qual se adiciona $15 \mathrm{~g} / \mathrm{L}$ de ágar bacteriológico), e a placa foi incubada por 20 horas a 37ํㅡ (estufa Ethikctechnology). Uma colônia de 2-3 milímetros de diâmetro foi escolhida, coletada com palito de madeira autoclavado e transferido para um tubo de pré-inóculo contendo $5 \mathrm{~mL}$ de meio LB líquido (Luria-Bertani líquido: triptofano $10 \mathrm{~g} / \mathrm{L}$, extrato de levedura $5 \mathrm{~g} / \mathrm{L}$ e $\mathrm{NaCl} 10 \mathrm{~g} / \mathrm{L}, \mathrm{pH} 7,0)$. Depois, $2 \mathrm{~mL}$ do pré-inóculo foram transferidos para um frasco erlenmeyer de $1 \mathrm{~L}$ contendo $100 \mathrm{~mL}$ de meio $\mathrm{LB}$, o qual foi incubado a 37ㄷ em shaker (MaxQ 5000-THERMO) sob agitação vigorosa (200rpm) até que a cultura atingisse D.O.600nm $=0,4$. A medida de densidade óptica foi feita em espectrofotômetro (BioMATE 3 da THERMO). A cultura foi transferida para dois tubos falcon de $50 \mathrm{~mL}$ estéril e foi resfriada em gelo por 10 minutos. Então, as células foram recuperadas por centrifugação (centrífuga refrigerada HITACHI) a 5750 rpm por 10 minutos a $4^{\circ} \mathrm{C}$. O meio LB foi descartado, e os tubos foram virados, de forma invertida sobre papel toalha por 1 minuto, até que todo o meio fosse eliminado. Cada pellet foi ressuspendido em agitador do tipo vortex (Phoenix) em $15 \mathrm{~mL}$ de solução gelada $80 \mathrm{mM} \mathrm{MgCl}_{2}, 20 \mathrm{mM} \mathrm{CaCl}_{2}$. As células foram recuperadas por centrifugação a 5750rpm por 10 minutos a $4^{\circ} \mathrm{C}$. A solução foi descartada e o excesso foi retirado invertendo o tubo sobre papel toalha. Em seguida, cada pellet foi ressuspendido em $2 \mathrm{~mL}$ de solução gelada de $0,1 \mathrm{M} \mathrm{CaCl}_{2}$ e $0,5 \mathrm{~mL}$ de glicerol $50 \%$. Por fim, alíquotas de $100 \mu \mathrm{L}$ foram congeladas em nitrogênio líquido e armazenadas a $-80^{\circ} \mathrm{C}$.

\subsubsection{Transformação em células $\mathrm{DH} 5 \alpha \mathrm{CaCl}_{2}$ competentes}

O produto da reação de ligação foi adicionado às células de Escherichia coli $\mathrm{DH} 5 \alpha \mathrm{CaCl}_{2}$ competentes, e a transformação foi realizada pela técnica de choque térmico, no qual a mistura foi deixada em gelo por 20 minutos, depois aquecida a $42^{\circ} \mathrm{C}$ por 1 minuto e 30 segundos, e colocada novamente em gelo por 3 minutos. Então, foi adicionado $400 \mu \mathrm{L}$ de meio LB líquido previamente 
aquecido a $37^{\circ} \mathrm{C}$. A mistura foi deixada por 1 hora sob agitação a $200 \mathrm{rpm}$ e $37^{\circ} \mathrm{C}$. Em seguida, o produto da transformação foi aplicado em uma Placa de Petri já contendo meio LB sólido com o antibiótico kanamicina $50 \mu \mathrm{g} / \mathrm{mL}$, com o auxílio de uma alça de vidro previamente flambada. O plasmídeo recombinante (DNA da CDK13 ligado ao vetor pCR-Blunt) é resistente ao antibiótico, pois este vetor possui genes de resistência a ele. Sendo assim, apenas as colônias que cresceram a partir de células eficientemente transformadas aparecem nas placas, as quais foram incubadas a $37^{\circ} \mathrm{C}$ em estufa por aproximadamente 12 horas para o crescimento das colônias.

\subsubsection{PCR de colônias}

A confirmação da obtenção das colônias recombinantes foi feita por reações de PCR de colônias, nas quais se utilizou os primers M13 forward e M13 reverse $(100 \mathrm{ng} / \mu \mathrm{L})$, cujas sequências provêm do vetor, e também PCR de colônias utilizando os primers construídos para a CDK13 (Tabelas 6, 7, 8 e 9). Foram escolhidas algumas colônias, e cada uma delas foi solubilizada separadamente em $15 \mu \mathrm{L}$ de água autoclavada e incubada a $92^{\circ} \mathrm{C}$ por 5 minutos. Cada reação foi feita para um volume final de $10 \mu \mathrm{L}$ e a enzima utilizada foi a Phusion High-Fidelity PCR Master Mix (Finnzymes) ou Taq DNA polymerase (Fermentas). O produto da PCR foi analisado em gel de agarose, e para as colônias em que apareceu banda correspondente ao tamanho do fragmento de DNA da CDK13 (colônias positivas), foram feitos pré-inóculos. 
Tabela 6 - Reação de PCR de colônias com a enzima 2x Phusion Master Mix, para confirmação da obtenção de colônias positivas para DNA referente à CDK13.

\begin{tabular}{c|c}
\hline Reagentes & Volume $(\mu \mathrm{L})$ \\
\hline 2 x Phusion Master Mix (Finnzymes) & 5,0 \\
\hline $\begin{array}{c}\text { Primer Forward da CDK13 }(10 \mu \mathrm{M}) \text { ou } \\
\text { Primer M13 Forward }(100 \mathrm{ng} / \mu \mathrm{L})\end{array}$ & 0,4 \\
\hline $\begin{array}{c}\text { Primer Reverse da CDK13 }(10 \mu \mathrm{M}) \text { ou } \\
\text { Primer M13 Reverse }(100 \mathrm{ng} / \mu \mathrm{L})\end{array}$ & 0,4 \\
\hline DMSO & 0,2 \\
\hline DNA plasmidial & 4,0 \\
\hline Total & 10,0 \\
\hline
\end{tabular}

Tabela 7 - Programa do termociclador utilizado no PCR de colônias para confirmação da obtenção do DNA referente à CDK13.

\begin{tabular}{c|c|c}
\hline Temperatura $\left({ }^{\circ} \mathbf{C}\right)$ & Tempo & Etapa \\
\hline 98 & 30 segundos & Desnaturação \\
\hline 98 & 10 segundos & Desnaturação \\
\hline$*$ & 30 segundos & Anelamento \\
\hline 72 & 45 segundos & Extensão \\
\hline 72 & 10 minutos & Extensão final \\
\hline 4 & $\infty$ & \\
\hline
\end{tabular}

* 56드 para primer do vetor pCR-Blunt e 53,5ㄷ para o primer da CDK13. 
Tabela 8 - Reação de PCR de colônias com a enzima Taq DNA polymerase para confirmação da obtenção de colônias positivas para DNA referente à CDK13.

\begin{tabular}{c|c}
\hline Reagentes & Volume $(\mu \mathrm{L})$ \\
\hline $\begin{array}{c}\text { Taq DNA polymerase }(\text { Fermentas }) \\
\text { Primer M13 Forward }(100 \mathrm{ng} / \mu \mathrm{L})\end{array}$ & 0,25 \\
\hline $\begin{array}{c}\text { Primer Reverse da CDK13 }(10 \mu \mathrm{M}) \text { ou } \\
\text { Primer M13 Reverse }(100 \mathrm{ng} / \mu \mathrm{L})\end{array}$ & 0,5 \\
\hline 25mM MgCl 2 & 0,5 \\
\hline DNA plasmidial & 0,4 \\
\hline dNTPs $(10 \mathrm{mM})$ & 3,0 \\
\hline $10 \times$ Taq Buffer & 0,5 \\
\hline $\mathrm{H}_{2} \mathrm{O}$ & 1,0 \\
\hline Total & 3,85 \\
\hline
\end{tabular}

Tabela 9 - Programa do termociclador utilizado no PCR de colônias para confirmação da obtenção do DNA referente à CDK13.

\begin{tabular}{c|c|c}
\hline Temperatura $\left({ }^{\circ} \mathbf{C}\right)$ & Tempo & Etapa \\
\hline 95 & 3 minutos & Desnaturação \\
\hline 95 & 30 segundos & Desnaturação \\
\hline$*$ & 30 segundos & Anelamento \\
\hline 72 & 2 segundos & Extensão \\
\hline 72 & 15 minutos & Extensão final \\
\hline 4 & $\infty$ & \\
\hline
\end{tabular}

* 56ํㅡ para primer do vetor pCR-Blunt e 53,5ํㅡ para o primer da CDK13.

\subsubsection{Preparação de pré-inóculo}

Cada colônia positiva foi coletada com palito de madeira autoclavado, e transferida para um tubo de ensaio para pré-inóculo contendo $5 \mathrm{~mL}$ de meio LB líquido e o antibiótico kanamicina $50 \mu \mathrm{g} / \mathrm{mL}$. Os tubos foram incubados a $37^{\circ} \mathrm{C}$, a 200 rpm por 12 horas. 


\subsubsection{Purificação dos plasmídeos recombinantes}

Os plasmídeos recombinantes foram purificados do pré-inóculo pelo kit de extração GeneJET Plasmid Miniprep Kit (Fermentas). O produto da purificação foi analisado em gel de agarose.

\subsubsection{Reação de clivagem para liberação do DNA referente à CDK13}

A próxima etapa foi a de recuperação do inserto para a sua inserção no vetor de expressão pET28a(+) a partir do DNA plasmidial (também chamado plasmídeo recombinante - pCRBlunt::CDK13) que consiste do DNA correspondente à CDK13, o chamado inserto, e o vetor pCR-Blunt. Para isso, foi feita a reação de clivagem com as enzimas de restrição correspondentes aos sítios de restrição presentes nos primers da CDK13. Foram feitos testes de clivagem utilizando-se tampão com 100\% de eficiência para as enzimas Ndel e BamHI (New England BioLabs), e o tempo (4 horas) e temperatura $\left(37^{\circ} \mathrm{C}\right)$ de incubação utilizados foram os sugeridos pelos protocolos da enzima. Os produtos das reações foram analisados em gel de agarose.

\subsubsection{Construção do plasmídeo recombinante de expressão}

O plasmídeo recombinante pET28a::CDK13 foi sintetizado pela empresa EPOCH Life Science Inc. A partir de análise da sequência do DNA correspondente à CDK13 e da sequência do vetor pET28a(+) foi determinado que o DNA da CDK13 deveria ser ligado entre as posições das sequências das enzimas de restrição Ndel e Sacl do vetor.

Os vetores pET tem um sistema de expressão controlado pela transcrição da enzima T7 RNA polimerase do bacteriófago T7, a qual é bastante ativa e seletiva, podendo levar a tradução das proteínas alvo em sua forma insolúvel, principalmente quando estas são tóxicas às células. Para evitar isso, primeiramente o DNA correspondente à proteína alvo e ligado ao vetor de expressão pET, é clonado em células $E$. coli que não contêm o gene da T7 RNA polimerase. Depois, o plasmídeo é transferido para células de $E$. coli, como a BL21(DE3), que possui o gene da T7 RNA polimerase sob controle 
do operon lac (lacUV5). O repressor, produto do gene Lacl, fica ligado ao operador, impedindo a transcrição do DNA e tradução da proteína alvo, porém na presença do indutor natural 1,6-aldolactose, ou do análogo IPTG (isopropil$\beta$-D-1-tiogalactopiranosídeo), o repressor se desliga, a T7 RNA polimerase é expressa e pode atuar na transcrição do DNA correspondente à proteína alvo.

A T7 RNA polimerase é mais eficiente e produzida em maiores quantidades que a RNA polimerase nativa da E. coli, por isso, ao final da indução, praticamente todo conteúdo proteico é o correspondente ao DNA alvo do vetor $\mathrm{pET}$. $62,63,64$

O plasmídeo recombinante sintético pET28a::CDK13 foi utilizado no processo de transformação por meio de choque térmico em células de $E$. coli $\mathrm{DH} 5 \propto \mathrm{CaCl}_{2}$ competentes das quais foram selecionados os clones contendo $\mathrm{O}$ plasmídeo recombinante pelo uso de $50 \mu \mathrm{g} / \mathrm{mL}$ de kanamicina, nas placas contendo $20 \mathrm{ml}$ de meio LB sólido.

\subsubsection{Obtenção dos plasmídeos recombinantes de expressão}

Foi preparado pré-inóculo como explicado no item 3.3.8 Preparação de pré-inóculo, também com antibiótico kanamicina $50 \mu \mathrm{g} / \mathrm{mL}$.

Os plasmídeos recombinantes foram extraídos por Lise Alcalina com SDS $^{62}$ ou com kit de extração GeneJET Plasmid Miniprep Kit (Fermentas). Alíquotas do DNA plasmidial obtido a partir das células foram analisadas em eletroforese em gel de agarose e a concentração do DNA purificado foi determinada pelo equipamento Thermo Scientific NanoDrop ${ }^{T M} 1000$ Spectrophotometer.

\subsubsection{Sequenciamentos}

Os DNAs plasmidiais, pCR-Blunt::CDK13 e pET28a::CDK13 foram submetidos ao sequenciamento automático pelo método de dideoxi nucleotídeos, utilizando os primers do vetor em questão, e o equipamento 3130 Genetic Analyzer (Applied Biosystems), localizado no Laboratório de Biologia Molecular do Grupo de Cristalografia (IFSC). 
Este é um tipo de sequenciamento por terminação de cadeia, no qual se utiliza reação em cadeia da polimerase. São feitas quatro misturas de reações ao mesmo tempo, com primers que se ligam à extremidade 3' do DNA, desoxirribonucleosídeos trifosfatados (dNTPs), e uma pequena quantidade de um dos análogos dos desoxirribonucleosídeos trifosfatados, os 2',3' - dideoxi de um dos nucleotídeos (ddNTPs), cada um deles em uma das reações. Os análogos impedem a continuação da formação da fita complementar de DNA, pois não possuem a hidroxila 3' para a formação da ligação fosfodiéster e cada um possui um marcador fluorescente. São formadas sequências de DNA truncadas de diferentes tamanhos após a reação de PCR, por causa da terminação da reação em cadeia da polimerase pela presença de um dos ddNTPs. As quatro misturas de reações são aplicadas em gel de poliacrilamida para eletroforese, que irá mostrar o padrão de bandas, e cada base terminal (ddNTP marcado) é identificada pelo seu espectro de fluorescência, por um sistema de detecção de fluorescência induzido por laser. ${ }^{58,59}$

\subsubsection{Modificação do plasmídeo recombinante pET28a::CDK13}

Foram desenhados primers para 0 plasmídeo recombinante pET28a::CDK13 para obter um plasmídeo, por reação de PCR, que codificasse apenas a região da proteína CDK13 que contém a região em torno do sítio ativo. Foram adicionados sítios para a enzima de restrição HindllI nos primers, como apresentado na Tabela 10.

Tabela 10 - Sequências dos primers utilizados na amplificação do DNA referente ao sítio de ligação da CDK13.

\begin{tabular}{c|c|c}
\hline Primers & $\begin{array}{c}\text { Enzimas } \\
\text { de } \\
\text { Restrição }\end{array}$ & Sequências dos primers 5'-3' \\
\hline Cdk13_Fw (5') & $\underline{\text { HindllI }}$ & AGG AAG CTT TGA CTC TAA ACG GGT CTT GAG \\
\hline Cdk13_Rv (3') & $\underline{\text { HindllI }}$ & AGG $\underline{\text { AAG CTT CTT TGG TTT CAT GGT GTT G }}$ \\
\hline
\end{tabular}


O plasmídeo pET28a::CDK13 foi utilizado como DNA molde, e a enzima Taq DNA polymerase (Fermentas), desoxirribonucleotídeos e os primers foram utilizados nas reações de PCR, como apresentado no item 3.3.1 Reação em cadeia da polimerase (PCR), e nas Tabelas 11 e 12.

Tabela 11 - Reação de PCR com a enzima Taq DNA polymerase para amplificação do plasmídeo recombinante $\mathrm{pET} 28:: \mathrm{CDK} 13$

\begin{tabular}{|c|c|}
\hline Reagentes & Volume $(\mu \mathrm{L})$ \\
\hline Taq DNA polymerase (Fermentas) & 0,25 \\
\hline Primer Forward da CDK13 (10 $\mu \mathrm{M})$ & 2,5 \\
\hline Primer Reverse da CDK13 (10 $4 \mathrm{M})$ & 2,5 \\
\hline $25 \mathrm{mM} \mathrm{MgCl} 2$ & 2,0 \\
\hline plasmídeo pET-28a::CDK13 (56ng/ $\mu \mathrm{L})$ & 0,02 \\
\hline Mix de dNTPs (2mM cada) & 1,0 \\
\hline $10 \times$ Taq Buffer & 5,0 \\
\hline $\mathrm{H}_{2} \mathrm{O}$ & 36,73 \\
\hline Total & 50,0 \\
\hline
\end{tabular}

Tabela 12 - Programa do termociclador utilizado para amplificação do plasmídeo recombinante pET28::CDK13.

\begin{tabular}{c|c|c}
\hline Temperatura $\left({ }^{\circ} \mathbf{C}\right)$ & Tempo & Etapa \\
\hline 95 & 3 minutos & Desnaturação \\
\hline 95 & 30 segundos & Desnaturação \\
\hline$*$ & 30 segundos & Anelamento \\
\hline 72 & 5 minutos & Extensão \\
\hline 72 & 10 minutos & Extensão final \\
\hline 4 & $\infty$ & \\
\hline
\end{tabular}

${ }^{*}$ Gradiente de temperatura de 75 a $52^{\circ} \mathrm{C}$.

Os produtos das reações de PCR foram analisados em gel de agarose, como descrito no item 3.3.2 Eletroforese em gel de agarose. Após determinar as melhores condições da reação de PCR, uma reação de $50 \mu \mathrm{L}$ foi realizada e 
todo esse conteúdo foi aplicado em gel de agarose. Após a eletroforese, foi feita a purificação do plasmídeo recombinante com o kit Gene Jet Gel Extraction da Fermentas. Depois, o plasmídeo recombinante foi submetido a uma reação de clivagem com a enzima Hindlll (New England BioLabs) e tampão NE Buffer 2, a qual foi incubada por 15 horas a $37^{\circ} \mathrm{C}$, e então a uma reação de ligação com a enzima T4 DNA ligase e $10 \mathrm{mM}$ de ATP, que foi incubada por 50 minutos a $25^{\circ} \mathrm{C}$.

\subsection{Expressão}

\subsubsection{Testes de expressão}

Foram feitos testes de expressão com as cepas de E. coli listados na Tabela 13, utilizando o plasmídeo recombinante pET28a::CDK13 sintético: 
Tabela 13 - Cepas utilizadas nos testes de expressão e suas características principais.

\begin{tabular}{|c|c|}
\hline Cepas & Características \\
\hline BL21(DE3) & $\begin{array}{l}\checkmark \text { BL21 é deficiente nas proteases lon e ompT } \\
\checkmark \text { DE3 carrega uma cópia do gene da T7 RNA } \\
\text { polimerase sob o controle do promotor } \\
\text { LacUV5 }\end{array}$ \\
\hline BL21(DE3)pLysS & $\begin{array}{l}\text { Possui um plasmídeo que codifica a lisozima } \\
\text { T7, um inibidor natural da T7 RNA polimerase } \\
\checkmark \quad \text { Tem resistência ao antibiótico cloranfenicol } \\
34 \mu \mathrm{g} / \mathrm{mL}\end{array}$ \\
\hline BL21(DE3)pLysE & $\begin{array}{l}\checkmark \text { Possui um plasmídeo que codifica a lisozima, } \\
\text { porém expressa a lisozima T7 em } \\
\text { concentrações maiores que a pLysS } \\
\text { conferindo maior controle sobre a polimerase, } \\
\text { é utilizada geralmente, quando a proteína } \\
\text { recombinante expressa é tóxica para a célula } \\
\checkmark \text { Tem resistência ao antibiótico cloranfenicol } \\
34 \mu \mathrm{g} / \mathrm{mL}\end{array}$ \\
\hline BL21(DE3)-CodonPlus-pRIL & $\begin{array}{l}\text { Possui tRNAs para os códons AGA/AGG, } \\
\text { AUA e CUA (códons RIL) raros em E.coli, } \\
\checkmark \quad \text { Tem resistência ao cloranfenicol } 20 \mu \mathrm{g} / \mathrm{mL}\end{array}$ \\
\hline Origami(DE3) & $\begin{array}{ll}\checkmark & \text { Favorece a formação de ligações dissulfeto } \\
\checkmark & \text { Possui resistência à kanamicina } 30 \mu \mathrm{g} / \mathrm{mL} \text { e } \\
& \text { tetraciclina } 10 \mu \mathrm{g} / \mathrm{mL}\end{array}$ \\
\hline Rosetta(DE3) & $\begin{array}{l}\text { Possui tRNAs para os códons AUA, AGG, } \\
\text { AGA, CUA, CCC, GGA, raros em E. coli } \\
\checkmark \quad \text { Tem resistência ao cloranfenicol } 20 \mu \mathrm{g} / \mathrm{mL} ;\end{array}$ \\
\hline BL21(DE3)pTGroE & $\begin{array}{ll}\checkmark & \text { Expressa as chaperoninas GroES e GroEL } \\
\checkmark & \text { Resistência ao cloranfenicol } 34 \mu \mathrm{g} / \mathrm{mL}\end{array}$ \\
\hline
\end{tabular}

A transformação foi feita pelo método de choque térmico como apresentado em 3.3.6 Transformação em células $\mathrm{DH} 5 \alpha \mathrm{CaCl}_{2}$ competentes. As colônias foram selecionadas em meio LB sólido contendo os antibióticos específicos para cada cepa de E. coli e para o plasmídeo recombinante. 
A partir das Placas de Petri em que cresceram colônias foram feitos préinóculos como indicado no item 3.3.8 Preparação de pré- inoculo, com os antibióticos específicos para cada cepa e para o plasmídeo recombinante.

Uma alíquota de $1 \mathrm{~mL}$ do pré-inóculo foi transferida para erlenmeyer contendo $100 \mathrm{~mL}$ de meio LB líquido e os antibióticos correspondentes. As colônias foram deixadas sob agitação constante de $200 \mathrm{rpm}$ a $37^{\circ} \mathrm{C}$ até que atingissem densidade ótica à $600 \mathrm{~nm}$ de 0,4 a 0,6 unidades de absorbância. Então, foi adicionado IPTG (isopropil $\beta$-D-1-tiogalactopiranosídeo) (foram feitos testes com concentrações finais de 0,$1 ; 0,2 ; 0,4 ; 0,6$ ou $0,8 \mathrm{mmol} / \mathrm{L}$ para algumas cepas), e a temperatura foi alterada (testes em $30^{\circ}, 20^{\circ} \mathrm{C}$ ou mantida a $37^{\circ} \mathrm{C}$ ) e a indução foi realizada por algumas horas (testes de 4 horas ou overnight).

Alíquotas de $1 \mathrm{~mL}$ do meio de indução foram retiradas antes e após a adição de IPTG, e foram centrifugadas por 2 minutos a 8000rpm para recuperação das células, as quais foram ressuspendidas em $40 \mu \mathrm{L}$ de água autoclavada e armazenadas a $-20^{\circ} \mathrm{C}$ para posterior eletroforese em gel de poliacrilamida.

Aproximadamente $100 \mathrm{~mL}$ de meio contendo as células após a indução foram centrifugados a $8000 \mathrm{rpm}$ por 20 minutos a $4^{\circ} \mathrm{C}$, e as células foram armazenadas à $-20^{\circ} \mathrm{C}$ para posterior teste de lise celular para recuperação da proteína CDK13.

Após os testes de expressão, foram determinados os melhores parâmetros de tempo, temperatura e concentração de IPTG para $500 \mathrm{~mL}$ de meio líquido.

\subsubsection{Testes de expressão em meio de auto-indução}

O meio de auto-indução pode ser utilizado para cepas que são induzidas com a adição de IPTG à cultura, entretanto nesse meio não se usa IPTG como indutor. O princípio desta técnica de indução se baseia nas fontes de carbono disponíveis para as células que são metabolizadas em momentos diferentes durante o crescimento das células e que ativam automaticamente a indução de proteínas sob o controle de promotores lac. 
Alguns estudos mostraram que o meio de auto-indução produz quantidades significativas de várias proteínas recombinantes (proteínas alvo), inclusive aquelas que podem ser altamente tóxicas para as células, já que os níveis de expressão de proteína durante a fase de crescimento das células são muito pequenos. Geralmente as proteínas alvo são produzidas em quantidade maior que em meio LB líquido e em sua forma solúvel. Foi relatado que em experimentos de expressão de 192 proteínas, 84 foram expressas solúveis. ${ }^{65}$

O meio permite que as células cresçam até atingirem uma alta densidade celular, seguida da indução da expressão da proteína alvo espontaneamente. A glicose é o açúcar preferencialmente metabolizado durante o crescimento das células, ao invés de açúcares indutores. Quando a concentração de glicose diminui, a lactose presente na triptona (hidrolisado de caseína) é transportada para dentro das células e convertida pela $\beta$ galactosidase no indutor alolactose, o qual causa a liberação do repressor do operon lac, induzindo a expressão da T7 RNA polimerase do promotor LacUV5, permitindo a expressão da proteína de interesse. ${ }^{66}$

O meio de auto-indução contém:

Triptona e extrato de levedura que são as fontes de nitrogênio para o meio, sendo que o segundo é fonte de vitaminas $B$, carboidratos e fatores de crescimento. Sulfato de amônio é adicionado para aumentar a síntese proteica. D-glicose e a-lactose são as fontes de carbono. A glicose se encontra em concentração suficiente para crescimento até alta densidade das células, seguido de indução pela consequente conversão de lactose em alolactose. Se estabelece um tampão fosfato para reduzir a queda no $\mathrm{pH}$ por causa do metabolismo da glicose. Sulfato de magnésio é adicionado para garantir a saturação celular, já que esta é geralmente limitada pela falta deste composto. Alta densidade celular e alta taxa de expressão de proteínas podem requerer uma quantidade adicional de elementos traços, além da que já existe na triptona e extrato de levedura, por isso são adicionados ao meio: $\mathrm{CaCl}_{2}, \mathrm{MnCl}_{2}$, $\mathrm{ZnSO}_{4}, \mathrm{CoCl}_{2}, \mathrm{CuCl}_{2}, \mathrm{NiCl}_{2}, \mathrm{Na}_{2} \mathrm{MoO}_{4}, \mathrm{Na}_{2} \mathrm{SeO}_{3}, \mathrm{H}_{3} \mathrm{BO}_{3}$, e também $\mathrm{FeCl}_{3}$. Glicerol é adicionado como uma fonte adicional de carbono, já que a lactose pode não ser uma fonte tão boa. ${ }^{66}$ 
A auto-indução ocorre melhor em baixas temperaturas de 18 a $37^{\circ} \mathrm{C}$ (por causa da maior solubilidade de oxigênio em baixas temperaturas) e com bastante aeração para facilitar o alcance da alta densidade de células. ${ }^{65}$

Após o crescimento das células em pré-inóculo com $5 \mathrm{~mL}$ de meio LB líquido e os antibióticos correspondentes da cepa, $1 \mathrm{~mL}$ do pré-inóculo foi adicionado em erlenmeyer de $500 \mathrm{~mL}$ com $50 \mathrm{~mL}$ de meio de auto-indução ZYP5052 (Tabela 14) e os antibióticos correspondentes. As células foram deixadas em shaker a 200 rpm, $20^{\circ} \mathrm{C}$ por 72 horas.

Tabela 14 - Composição do meio de auto-indução ZYP-5052. ${ }^{66}$

\begin{tabular}{c|c}
\hline Componentes & Concentração \\
\hline Triptona & $1 \%$ \\
\hline Extrato de levedura & $0,5 \%$ \\
\hline $\mathrm{Na}_{2} \mathrm{HPO}_{4}$ & $50 \mathrm{mM}$ \\
\hline $\mathrm{KH}_{2} \mathrm{PO}_{4}$ & $50 \mathrm{mM}$ \\
\hline$\left(\mathrm{NH}_{4}\right)_{2} \mathrm{SO}_{4}$ & $25 \mathrm{mM}$ \\
\hline Glicerol & $0,5 \%$ \\
\hline Glicose & $0,05 \%$ \\
\hline$\alpha$-lactose & $0,2 \%$ \\
\hline MgSO & $2 \mathrm{mM}$ \\
\hline Elementos traço & $0,2 \times$ \\
\hline
\end{tabular}

Alíquotas de $1 \mathrm{~mL}$ do pré-inóculo (amostra não induzida) e do meio de auto-indução, após as 72 horas, foram retiradas e centrifugadas por 2 minutos a 8000rpm para recuperação das células, as quais foram ressuspendidas em $40 \mu \mathrm{L}$ de água autoclavada e armazenadas a $-20^{\circ} \mathrm{C}$ para posterior eletroforese em gel de poliacrilamida.

Os aproximadamente $50 \mathrm{~mL}$ de meio contendo as células após a indução foram centrifugados a $8000 \mathrm{rpm}$ por 20 minutos a $4^{\circ} \mathrm{C}$, e as células foram armazenadas à $-20^{\circ} \mathrm{C}$ para posterior teste de lise celular para recuperação da proteína CDK13. 


\subsubsection{Gel de poliacrilamida $12 \%$ para análise dos testes de indução}

As alíquotas retiradas das amostras induzidas e não induzidas que foram ressuspendidas em água autoclavada foram misturadas a 40 $\mathrm{L}$ (amostra não induzida) e 160 $\mu \mathrm{L}$ (amostra induzida) de tampão de amostra com $\beta$ mercaptoetanol ou DTT (ditiotreitol), e foram aplicadas em gel de poliacrilamida na presença de dodecil sulfato de sódio (SDS-PAGE), com gel de empacotamento 5\%, gel de separação 12\%, voltagem de 100 Volts por aproximadamente 90 minutos. Foi utilizado o equipamento Mini-Protean II Dual Slab Cell (Bio-Rad) para a eletroforese. O gel foi corado com Coomassie Brilliant Blue $R$ (Bio-Rad) 0,25\% e etanol:ácido acético:água 5:1:15 (v:v:v) por 10 minutos e descorado em ácido acético:etanol:água 3:2:35 (v:v:v). O padrão de massa molecular Unstained Protein Molecular Weight Marker 14,4-116kDa (Fermentas), foi submetido à eletroforese assim como as amostras, para comparação das bandas de proteína do marcador, com as bandas de proteínas das amostras, e assim analisar a expressão da CDK13.

O gel de poliacrilamida é formado pela polimerização de acrilamida e N,N'-metilenobisacrilamida, com o PSA (persulfato de amônio) como agente polimerizante formando radicais livres quando o catalisador TEMED (N,N,N,N'tetrametilenodiamina) é adicionado. O dodecil sulfato de sódio (SDS) é um detergente, e forte desnaturante de proteínas. A associação hidrofóbica entre ele e os resíduos apolares das proteínas interferem com as interações hidrofóbicas que estabilizam a estrutura nativa delas. As proteínas adotam uma forma alongada com carga negativa, por causa da carga do SDS, apresentando relação massa/carga idênticas e formas semelhantes sendo então, separadas de acordo com sua massa molecular. Os poros do gel têm efeito filtrador retardando as moléculas maiores em relação às menores. ${ }^{3}$

Após os testes de expressão, foram determinados os melhores parâmetros de tempo e temperatura para $500 \mathrm{~mL}$ de meio de auto-indução. 


\subsubsection{Lise das células}

As células advindas das amostras de indução foram submetidas ao processo de lise celular. Foram adicionados $5 \mathrm{~mL}$ de tampão de lise para cada $100 \mathrm{~mL}$ de cultura. Alguns tipos de tampão de lise foram utilizados em diferentes culturas,

- Tampão A: 50mM Tris pH8,0, 100mM KCl;

- Tampão B: 10mM Tris-HCl pH7,4, 25mM de $\mathrm{NaCl}$ e $1 \mathrm{mM}$ de EDTA;

- Tampão C: (para lise Freeze-Thaw) 20mM Tris, $250 \mathrm{mM} \mathrm{KCl,} 10 \%$ glicerol;

- Tampão D: (para purificação em coluna de $\mathrm{Ni}^{2+}$ ) 50mM Tris pH 8,0, 300mM KCl, 5mM DTT, 5\% glicerol;

- Tampão E: (para purificação em coluna de ATP) 10mM Hepes pH7,4, $25 \mathrm{mM} \mathrm{NaCl}, 1 \mathrm{mM}$ EDTA, 10\% glicerol (v/v) e 0,5mM DTT.

O processo de lise foi feito em duas etapas: a primeira etapa foi química com a ação de lisozima com concentração final de $0,5 \mathrm{mg} / \mathrm{mL}$ para digestão da parede bacteriana e DNase 0,5U para degradação de DNA presente no meio. Após a adição dos reagentes, a amostra foi mantida a $37^{\circ} \mathrm{C}$ por 30 minutos, depois foi submetida à segunda etapa de lise: física. A amostra foi lisada no sonicador Branson Sonifier Modelo S250A da Soni-Tech Ultrasonic-Systems com oito pulsos de 30 segundos com intervalos de 2 minutos, para aumentar 0 número de células lisadas e a concentração de proteína solúvel. Em seguida, a amostra foi centrifugada a $9000 \mathrm{rpm}$, por 20 minutos a $4^{\circ} \mathrm{C}$. O sobrenadante e 0 pellet foram armazenados a $-20^{\circ} \mathrm{C}$, até a análise em gel de poliacrilamida.

A uma alíquota de $40 \mu \mathrm{L}$ de sobrenadante foi adicionado $40 \mu \mathrm{L}$ de tampão de amostra com $\beta$-mercaptoetanol; o pellet foi ressuspendido no próprio tampão de lise, em aproximadamente $5 \mathrm{~mL}$ e a uma alíquota de $40 \mu \mathrm{L}$ desta solução também foi adicionado $40 \mu \mathrm{L}$ de tampão de amostra, e foram submetidas à eletroforese em gel de poliacrilamida $12 \%$ na presença de dodecil sulfato de sódio (SDS-PAGE).

Após a determinação dos melhores parâmetros para expressão e lise, foi feita uma indução para um volume de $500 \mathrm{~mL}$ de meio LB líquido, e o sobrenadante foi submetido à purificação por afinidade ao $\mathrm{Ni}^{2+}$. 
Lise por Freezing and Thawing:

O sedimento celular foi submetido a 10 ciclos consistindo de: 1 minuto em banho de gelo e água, seguido de 1 minuto em banho de gelo seco e etanol. Em seguida, foi ressuspendido em tampão $20 \mathrm{mM}$ Tris, $250 \mathrm{mM} \mathrm{KCl}$, $10 \%$ glicerol, e centrifugado a $14000 \mathrm{rpm}$, a $4^{\circ} \mathrm{C}$, por 15 minutos. O pellet foi ressuspendido em $4 \mathrm{~mL}$ de água deionizada. A cada $40 \mu \mathrm{L}$ de amostras do sobrenadante e pellet foram adicionados $20 \mu \mathrm{L}$ de tampão de amostra com DTT, e estas foram submetidas à eletroforese em gel de poliacrilamida.

\subsection{Purificação}

\subsubsection{Coluna de afinidade ao $\mathrm{Ni}^{2+}$}

O sobrenadante foi centrifugado a $4000 \mathrm{rpm}$ por 10 minutos a $4^{\circ} \mathrm{C}$ para retirar impurezas. A purificação por cromatografia de afinidade por $\mathrm{Ni}^{2+}$ foi feita com a coluna Profinity IMAC Ni-Charged Resin (BioRad), de $4 \mathrm{~mL}$, pois a proteína produzida tem cauda de histidina. Soluções com concentrações 50 , 100, 250 e $500 \mathrm{mM}$ de imidazol em tampão de lise foram utilizadas para eluir a proteína. A cada $40 \mu \mathrm{L}$ das frações coletadas foram adicionados $40 \mu \mathrm{L}$ de tampão de amostra com DTT e estas amostras foram submetidas à eletroforese em gel de poliacrilamida $12 \%$ na presença de dodecil sulfato de sódio (SDS-PAGE).

A cromatografia de afinidade se baseia na habilidade de proteínas se ligarem fortemente, mas não covalentemente, a certas moléculas. As moléculas conhecidas como ligantes que se ligam especificamente à proteína são acopladas covalentemente a uma matriz porosa inerte. Quando a solução impura é passada pela coluna, a proteína de interesse se liga ao ligante imobilizado (fase estacionária), e as outras substâncias são levadas pelo tampão (fase móvel). A proteína de interesse é recuperada pela passagem de outra substância com maior afinidade pelo ligante, liberando a proteína de interesse. A matriz porosa inerte da coluna possui o quelante ácido iminodiacético (IDA), o qual se liga a metais de transição, no caso o $\mathrm{Ni}^{2+}$. A proteína CDK13 produzida tem uma sequência de histidinas (His-tagged), e 
esses resíduos possuem forte afinidade por metais, como o da coluna de cromatografia utilizado. Assim, a proteína CDK13 se liga à coluna e é separada das outras substâncias, em seguida, a proteína é eluída pela passagem de soluções de diferentes concentrações de imidazol, uma molécula que possui afinidade pelo metal $\mathrm{Ni}^{2+}$, e que compete com os resíduos de histidinas (Histagged) da proteína, e se liga à coluna. ${ }^{3}$

\subsubsection{Coluna de afinidade ao ATP}

O sobrenadante foi centrifugado a $4000 \mathrm{rpm}$ por 10 minutos a $4^{\circ} \mathrm{C}$ e aplicado à coluna de afinidade ao ATP (Sigma). Foi utilizado uma coluna de $2 \mathrm{~mL}$ e a eluição foi feita com soluções de $\mathrm{NaCl} 50,100,250$ e $500 \mathrm{mM}$ em tampão Tris pH 7,5 (10mM TrisHCl; $25 \mathrm{mM} \mathrm{NaCl,} 1 \mathrm{mM}$ EDTA; $10 \%$ glicerol; $0,5 \mathrm{mM}$ DTT). As frações coletadas $(40 \mu \mathrm{L}$ com $40 \mu \mathrm{L}$ de tampão de amostra com DTT) foram analisadas por eletroforese em gel SDS-PAGE $12 \%$.

\subsection{Western Blot}

A detecção da proteína foi feita pelo método de Western Blot (também conhecido como immunoblot), no qual a proteína de interesse é identificada pela sua ligação a um anticorpo específico que pode ser detectado, por exemplo, ao ser acoplado a um isótopo radioativo, uma enzima detectável, ou a um corante fluorescente e isto é analisado por uma reação que gera cor, levando ao aparecimento de bandas das proteínas de interesse que se ligaram ao anticorpo.

A técnica se baseia em primeiramente separar as proteínas em gel de poliacrilamida, seguida da transferência destas para uma folha de nitrocelulose ou membrana de náilon ou de fluoreto de polivinilidina (PVDF), as quais ligam as proteínas forte e inespecificamente (a membrana é colocada sobre o gel e as proteínas são direcionadas para fora dele por um campo elétrico forte). Depois, os sítios de adsorção ao anticorpo disponíveis e em excesso da membrana, são bloqueados com uma proteína como a caseína, de leite 
desnatado. A membrana é então colocada em contato com a solução de anticorpo específico para revelar a proteína de interesse.

Geralmente, é utilizado um anticorpo primário, como o de coelho. Depois de lavar a membrana para retirar o excesso do anticorpo, a membrana é incubada com o anticorpo secundário, como o de cabra que é específico para os anticorpos de coelho e ao qual foi ligado covalentemente uma enzima de fácil detecção. A membrana é lavada novamente para retirar excesso de anticorpo não ligado e a enzima é detectada por uma reação que gera cor, mostrando as bandas coloridas referentes à proteína de interesse. ${ }^{2,3}$

$O$ experimento foi realizado em colaboração com o Laboratório de Bioquímica Funcional e Estrutural (LBFE - Universidade Federal de São Carlos (UFSCar)) coordenado pela Profa. Dra. Dulce Helena Ferreira de Souza, e com - Laboratório de Bioanalítica, Microfabricação e Separações (BioMicS IQSC/USP), coordenado pelo Prof. Dr. Emanuel Carrilho.

As amostras foram submetidas à eletroforese em gel de poliacrilamida $12 \%$ na presença de dodecil sulfato de sódio (SDS-PAGE). Em seguida, foi feita a transferência das proteínas do gel de poliacrilamida para a membrana de nitrocelulose: a membrana de nitrocelulose, papel de filtro e esponjas foram deixados na presença de tampão de transferência (Tris base $8 \mathrm{mM}$, glicina $23 \mathrm{mM}$ e metanol $0,11 \mathrm{mM}$ ) por 20 minutos, e então foi feita a montagem do chamado sandwich, no qual primeiro se posiciona uma esponja, sobre ela, o papel de filtro, acima dele se posiciona a membrana de nitrocelulose, sobre a qual se coloca o gel, por fim se coloca mais um papel de filtro e sobre eles outra esponja. Esse conjunto foi montado sobre uma placa chamada cassete, a qual foi submetida à transferência em cuba da BioRad por 2 horas, a 100V.

A membrana foi colocada em presença do corante Ponceau por 3 minutos para detectar as proteínas presente na membrana, e depois descorada com água destilada. Então, a membrana foi colocada em presença de solução de bloqueio (Leite em pó desnatado Molico $2,5 \mathrm{~g}$ em 50mL de 1X TBS) por 12 horas. A caseína, proteína do leite, bloqueia os sítios de adsorção em excesso na membrana, evitando a adsorção inespecífica do anticorpo.

A solução de bloqueio foi descartada e a membrana lavada três vezes com tampão TBS $1 \mathrm{X} 0,25 \mathrm{mM}$ Tween 20, por 5 minutos cada vez, sob leve 
agitação. A solução de anticorpo Ni NTA AP Conjugate (Qiagen) diluído 1:1000 foi adicionada sobre a membrana e após 2 horas sob leve agitação, a solução foi removida. A membrana foi lavada mais três vezes com tampão TBS $1 \mathrm{X}$ $0,25 \mathrm{mM}$ Tween 20, por 5 minutos cada vez, sob leve agitação. Por fim, a membrana foi colocada em solução reveladora (1 pastilha Fast BCIP/NPT Sigma diluída em $10 \mathrm{~mL}$ de água) por 4 horas. 


\section{RESULTADOS E DISCUSSÃO}

\subsection{Obtenção da sequência de nucleotídeos da CDK13}

Foram encontradas duas isoformas da CDK13 de Homo sapiens, porém o trabalho foi baseado na isoforma 1 (referência NCBI NP_003709.3), a qual possui 1512 aminoácidos. Após análise da sequência foi escolhida a região destacada em amarelo (Figura 13) para ser expressa de forma heteróloga, a qual inclui a região relacionada à sequência de aminoácidos PITAIRE do sítio ativo da proteína e despreza a região rica em serina e arginina (RS). A região rica em $\mathrm{RS}$ é típica de proteínas que atuam na transcrição e serve de local para ancoragem do CTD da RNAPII e, portanto, corresponde a uma região mais flexível e de estrutura tridimensional aleatória. Sendo assim, não seria uma região viável para ser expressa para estudos estruturais, podendo dificultar o enovelamento do restante da proteína. A proteína CDK13 possui alta massa molecular, o que dificulta a sua expressão na forma solúvel e ativa em $E$. coli, sendo assim, uma alternativa é expressar regiões (domínios) da proteína. 
Figura 13 - Sequência de aminoácidos em código de uma letra da proteína CDK13. A região destacada em amarelo foi a escolhida para ser expressa. A sequência de aminoácidos PITAIRE do sítio ativo está destacada em cinza.

\begin{abstract}
>gi|145309302|ref|NP_003709.3| cyclin-dependent kinase 13 isoform 1 [Homo sapiens]

MPSSSDTALGGGGGLSWAEKKLEERRKRRRFLSPQQP PLLLPLLQPQLLQP PP P P P PLLFLAAPGTAAAA AAAAAAS S SCFSPGPPLEVKRLARGKRRAGGRQKRRRGPRAGQEAEKRRVFSLPQPQQDGGGGASSGGGV TPLVEYEDVSSQSEQGLLLGGASAATAATAAGGTGGSGGSPASSSGTQRRGEGSERRPRRDRRSSSGRSK ERHREHRRRDGQRGGSEASKSRSRHSHSGEERAEVAKSGSSSSS GGRRKSASATS S S SS SRKDRDSKAHR SRTKSSKEPPSAYKEPPKAYREDKTEPKAYRRRRSLSPLGGRDDS PVSHRASQS LRSRKS P S PAGGGSSP YSRRLPRSPSPYSRRRSPSYSRHSSYERGGDVSPSPYSSSSWRRSRSPYSPVLRRSGKSRSRSPYSSRHS RSRSRHRLSRSRSRHSS ISPSTLTLKSSLAAELNKNKKARAAEAARAAEAAKAAEATKAAEAAAKAAKAS NTSTPTKGNTETSASASQTNHVKDVKKIKIEHAPSPSSGGTLKNDKAKTKPPLQVTKVENNLIVDKATKK AVIVGKESKSAATKEESVSLKEKTKPLTPS IGAKEKEQHVALVTSTLPPLPLP PMLPEDKEADSLRGNIS VKAVKKEVEKKLRCLLADLPLPPELPGGDDLSKSPEEKKTATQLHSKRRPKICGPRYGETKEKDIDWGKR CVDKFDI I GI I GEGTYGQVYKARDKDTGEMVALKKVRLDNEKEGFPITAIREIKILRQLTHQS I INMKE I VTDKEDALDFKKDKGAFYLVFEYMDHDLMGLLESGLVHFNENH I KSFMRQLMEGLDYCHKKNFLHRDIKC SNILLNNRGQIKLADFGLARLYSSEESRPYTNKVITLWYRP PELLLGEERYTPA I DVWSCGCILGELFTK KPIFQANQELAQLELISRICGSPCPAVWPDVIKLPYFNTMKPKKQYRRKLREEFVF I PAAALDLFDYMLA LDPSKRCTAEQALQCEFLRDVEPSKMPPPDLPLWQDCHELWSKKRRRQKQMGMTDDVST IKAPRKDLSLG LDDSRTNTPQGVLPS SQLKSQGSSNVAPVKTGPGQHLNHSELA I LLNLLQSKTSVNMADFVQVLNIKVNS ETQQQLNKINLPAG I LATGEKQTDPSTPQQESSKPLGGIQPSSQTIQPKVETDAAQAAVQSAFAVLLTQL IKAQQSKQKDVLLEERENGSGHEASLQLRPPPEPSTPVSGQDDL IQHQDMRILELTPEPDRPRILPPDQR PPEPPEPP PVTEEDLDYRTENQHVPTTSSSLTDPHAGVKAALLQLLAQHQPQDDPKREGGIDYQAGDTYV STSDYKDNFGSSSESSAPYVSNDGLGSSSAPPLERRSF I GNSDIQSLDNYSTASSHSGGPPQPSAFSESF PSSVAGYGDIYLNAGPMLFSGDKDHRFEYSHGP IAVLANSSDPSTGPESTHPLPAKMHNYNYGGNLQENP SGPSLMHGQTWTSPAQGPGYSQGYRGHISTSTGRGRGRGLPY
\end{abstract}

Fonte: Protein Database. <http://www.ncbi.nlm.nih.gov/>. referência:NP_003709.3.

A sequência de aminoácidos da proteína foi submetida à ferramenta Blastn para obtenção da sequência de nucleotídeos correspondente. A sequência de nucleotídeos da isoforma 1 da CDK13 possui 6985pb (referência NCBI NM_003718.4). A região com 2694pb foi a amplificada na reação de PCR, por conter a região codificadora do sítio ativo da proteína CDK13 e por ser menor, o que facilita a ligação em vetor de clonagem e vetor de expressão e transformação em células de E. coli.

\title{
4.2 Clonagem
}

\subsubsection{Amplificação do DNA referente à CDK13 por PCR}

A amplificação por reação de PCR com a enzima Phusion High-Fidelity PCR Master Mix (Finnzymes) foi eficiente, porém foi necessário o uso de DMSO (dimetilsulfóxido) para facilitar a separação da fita dupla de DNA correspondente à $C D K 13$, a qual possui aproximadamente $44 \%$ de $\mathrm{C}+\mathrm{G}$ 
(http://www.sciencebuddies.org/science-fair-

projects/project_ideas/Genom_GC_Calculator.shtml).

A sequência de nucleotídeos correspondente a CDK13 foi amplificada nas cinco temperaturas de anelamento utilizadas, as quais foram escolhidas baseadas na $\mathrm{Tm}$ dos primers (entre 50 e $60^{\circ} \mathrm{C}$ ), como apresentado na Figura 14.

Figura 14 - Gel de agarose $0,8 \%$ mostrando a amplificação do DNA referente à CDK13, em várias temperaturas de anelamento. 1: Marcador GeneRuler 1Kb DNA Ladder (Fermentas). 2 a 6: DNA referente à CDK13 humana. Temperaturas de anelamento: 57,$2 ; 55,5 ; 54,3 ; 53,5 ; 53,0^{\circ} \mathrm{C}$, respectivamente. A banda de interesse possui $2694 \mathrm{pb}$ e está indicada pela seta do lado direito da Figura.

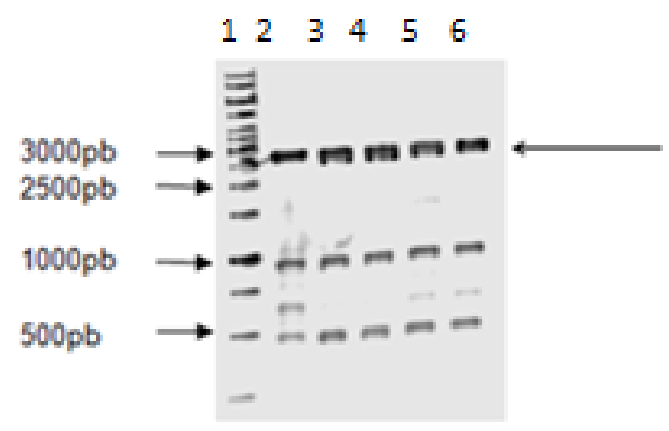

Fonte: Autoria própria.

A temperatura de anelamento de $54,3^{\circ} \mathrm{C}$ foi escolhida para uma reação de PCR de 50 $\mu$ L, pois pela intensidade da banda, a concentração de DNA amplificado foi alta. O produto da reação foi aplicado em gel de agarose $0,8 \%$ (Figura 15), a partir do qual foi purificado o DNA correspondente a CDK13 amplificado. 
Figura 15 - Gel de agarose $0,8 \%$ mostrando a amplificação do DNA referente à CDK13. 1: Marcador GeneRuler 1Kb DNA Ladder (Fermentas). 2: DNA referente à CDK13 humana. Reação com temperatura de anelamento $54,3^{\circ} \mathrm{C}$.

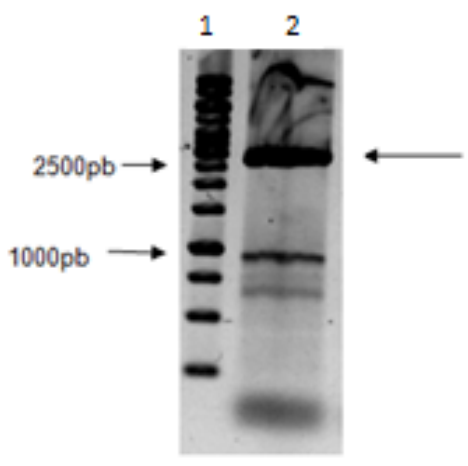

Fonte: Autoria própria.

A Figura 16 apresenta o gel de agarose do DNA da CDK13 purificado com o kit QI Aquick Gel Extraction (QIAGEN). A concentração determinada a $260 \mathrm{~nm}$ foi de $15 \mathrm{ng} / \mu \mathrm{L}$.

Figura 16 - Gel de agarose $0,8 \%$ mostrando o DNA referente à CDK13 purificado a partir de gel de agarose. 1: Marcador GeneRuler 1kb DNA Ladder (Fermentas). 2: DNA referente à CDK13 humana, após purificação com o kit QIAquick Gel Extraction (Qiagen) da reação com temperatura de anelamento $54,3^{\circ} \mathrm{C}$.

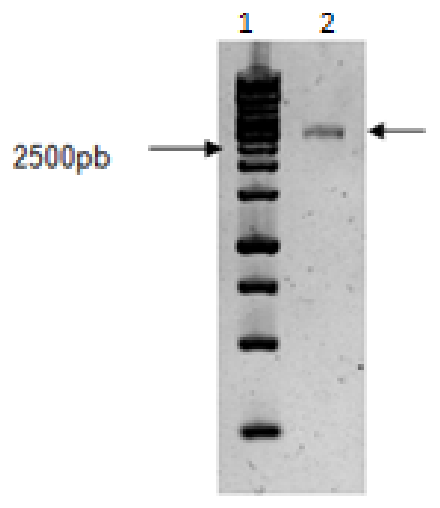

Fonte: Autoria própria.

\subsubsection{Obtenção do plasmídeo recombinante de clonagem pCR- Blunt::CDK13}

Após reação de ligação do DNA da CDK13 ao vetor de clonagem pCR-Blunt (Invitrogen), o plasmídeo recombinante de clonagem pCR-Blunt::CDK13 foi utilizado na transformação em células $E$. coli $\mathrm{CaCl}_{2}$ competentes. Algumas colônias cresceram, e para confirmação da obtenção de recombinantes foi 
realizada reação de PCR de colônias com os primers da CDK13 e com os primers do vetor (M13 Fw e M13 Rv).

A Figura 17 mostra que na reação de PCR de colônias com os primers do vetor não apareceu o DNA de tamanho esperado, enquanto que com os primers da CDK13 foi eficiente, ou seja, provavelmente a colônia possuía o plasmídeo recombinante. Esse resultado foi obtido com outras colônias e também com colônias obtidas de outras reações de transformação (resultados não mostrados), por isso, os experimentos seguintes foram realizados com essa colônia.

Figura 17 - Gel de agarose 0,8\% para análise de recombinantes por PCR de colônias. 1: Marcador GeneRuler 1Kb DNA Ladder (Fermentas). 2: Colônia a com primers específicos da CDK13. 3: Colônia a com primers do vetor (M13 Fw e M13 Rv), a banda de interesse não apareceu nessa canaleta.

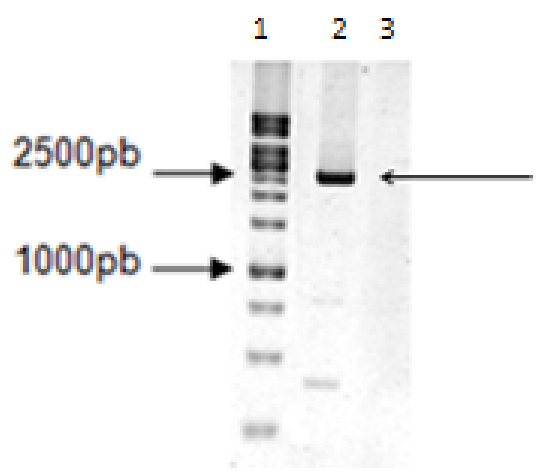

Fonte: Autoria própria.

A colônia com o plasmídeo recombinante foi utilizada para fazer préinóculo, a partir do qual o plasmídeo recombinante pCR-Blunt::CDK13 foi purificado com o kit de extração GeneJET ${ }^{T M}$ Plasmid Miniprep Kit (Fermentas) e analisado em gel de agarose, apresentado na Figura 18. Foi observado que 0 tamanho do plasmídeo recombinante purificado, de aproximadamente 6200pb, estava de acordo com o esperado (6194pb, sendo 3500pb do vetor pCR-Blunt e 2694pb do DNA da CDK13), o que confirmou que a colônia a continha o plasmídeo recombinante. A concentração encontrada a partir da leitura da amostra a $260 \mathrm{~nm}$ foi de $192,6 \mathrm{ng} / \mathrm{\mu L}$. 
Figura 18 - Gel de agarose $0,8 \%$ mostrando o plasmídeo recombinante pCRBlunt::CDK13. 1: Marcador GeneRuler 1Kb DNA Ladder. 2: Plasmídeo recombinante da colônia a . O tamanho do plasmídeo recombinante é de $6194 \mathrm{pb}$, referente a 3500pb do vetor pCR-Blunt e 2694pb do DNA referente à CDK13.

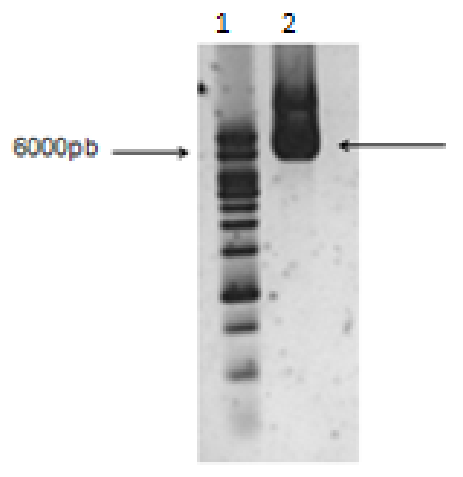

Fonte: Autoria própria.

\subsubsection{Reação de clivagem para liberação do DNA referente à CDK13}

O plasmídeo recombinante pCR-Blunt::CDK13 foi submetido à reação de clivagem para liberação do DNA correspondente à CDK13 e sua posterior ligação ao vetor de expressão. Como mostrado na Figura 19, o DNA referente à CDK13 não foi liberado do vetor, ou seja, não houve reação específica. Um fragmento de tamanho maior, aproximadamente 5000pb, foi o obtido, sendo que o esperado era de 2694pb. Foram feitos testes com as enzimas de restrição Ndel e BamHI da New England BioLabs e da ThermoScientific, por 4 horas a $37^{\circ} \mathrm{C}$ e 15 horas a $37^{\circ} \mathrm{C}$, e o resultado se repetiu.

Figura 19 - Gel de agarose 0,8\% mostrando o resultado da clivagem com Ndel e BamHI. 1: Marcador GeneRuler 1Kb DNA Ladder. 2: Controle (sem enzimas). 3: Digestão com a enzima Ndel. 4: com a enzima BamHI. 5: com ambas as enzimas Ndel e BamHI. 6: Controle. 7: Digestão com a enzima Ndel. 8: com a enzima BamHI. 9: com ambas as enzimas. Bandas 2 a 5: com as enzimas da BioLabs 4 horas a $37^{\circ} \mathrm{C}$. Bandas 6 a 9 enzimas da BioLabs 15 horas a $37^{\circ} \mathrm{C}$.

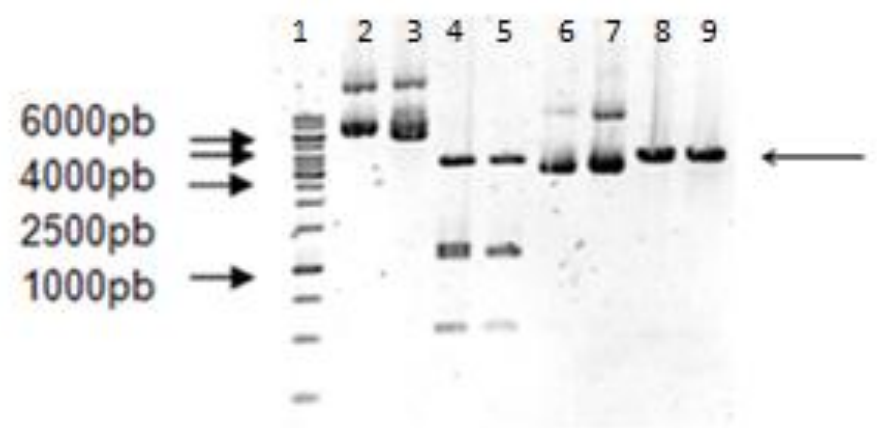

Fonte: Autoria própria. 
Após análise da sequência de DNA referente à CDK13, foi feito um teste de clivagem com as enzimas de restrição HindIII e BamHI por 4 horas a $37^{\circ} \mathrm{C}$. O sítio de restrição da enzima Hindlll é encontrado no vetor pCR-Blunt, porém não é encontrado na CDK13, sendo assim, essa enzima pôde ser utilizada para tentar liberar o DNA da CDK13, porém, ainda assim o DNA obtido de 3500pb foi maior que o esperado, em torno de 2751pb (2694pb da CDK13 mais 57pb do vetor), como mostrado na Figura 20.

Figura 20 - Gel de agarose 0,8\% mostrando o resultado da clivagem com Ndel e HindlII. 1: Marcador GeneRuler 1Kb DNA Ladder. 2: digestão com as enzimas Ndel e HindIII.

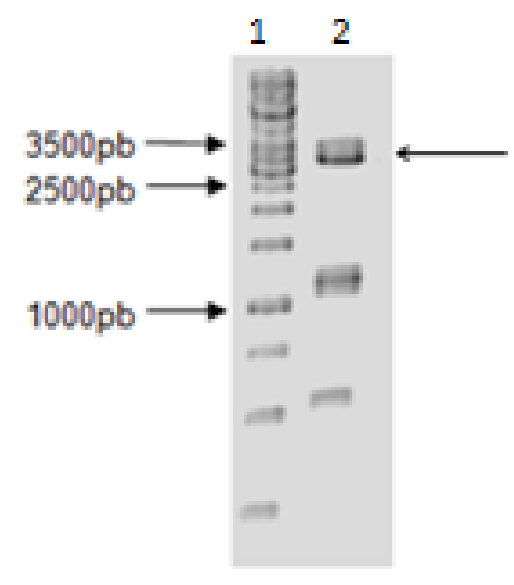

Fonte: Autoria própria.

Os resultados foram parecidos com os obtidos anteriormente ${ }^{67}$, por isso, foi feito sequenciamento do plasmídeo recombinante pCR-Blunt::CDK13 para verificar se existiam mutações em suas sequências iniciais 3' e 5' nos sítios de restrição das enzimas Ndel e BamHI. Entretanto, o sequenciamento (Figura 21) mostra que os sítios de restrição das enzimas estavam íntegros. Devido a estes resultados se decidiu partir para a construção do plasmídeo recombinante de expressão. 
Figura 21 - Sequenciamento automático do DNA referente à CDK13. A figura mostra o alinhamento das sequências obtidas a partir dos sequenciamentos realizados a partir das extremidades 5' (a) e 3' (b) do DNA. Observa-se que as regiões iniciais das extremidades 3' e 5', onde se encontram os sítios das enzimas de restrição, estão íntegros.

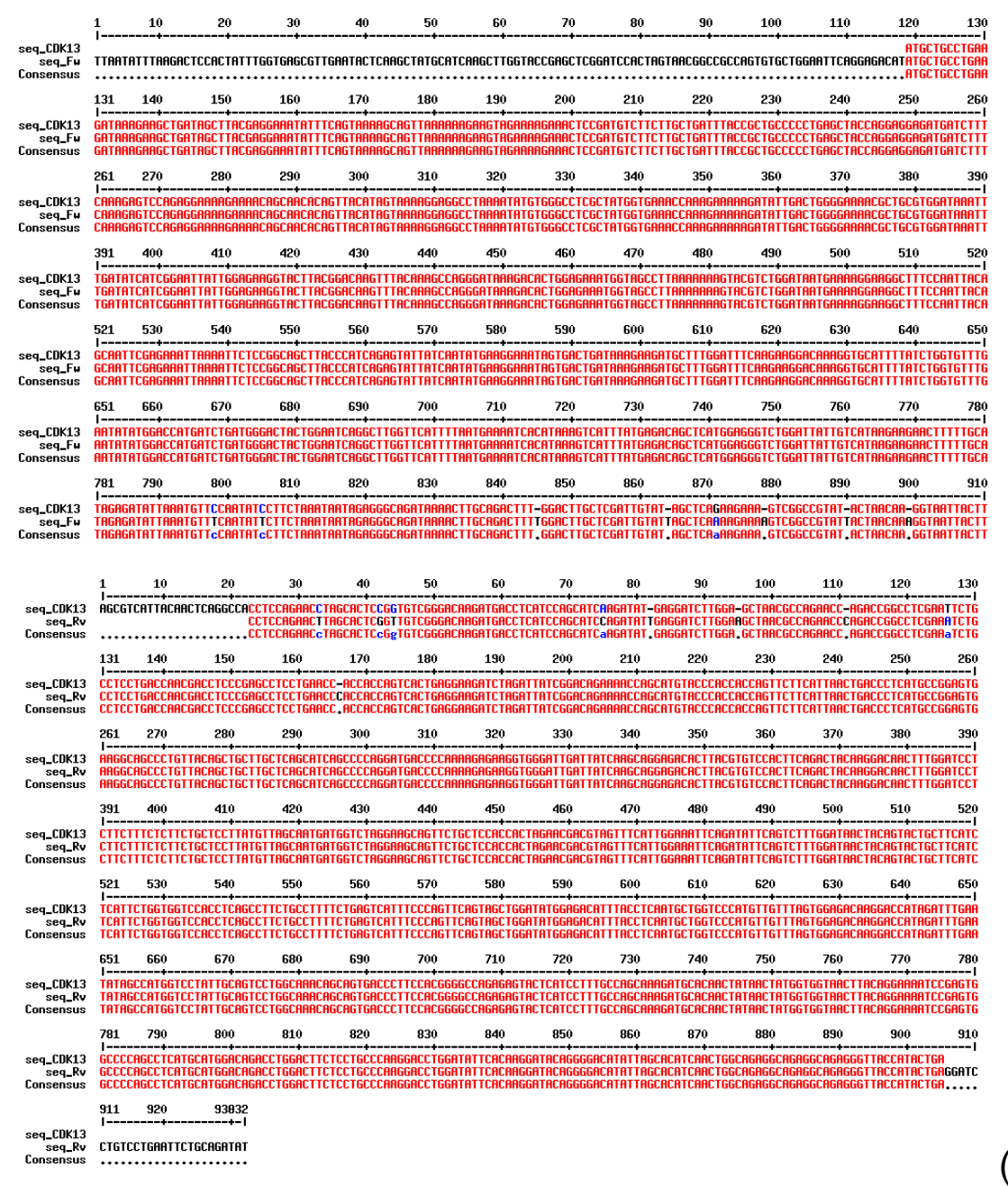

Fonte: Multiple sequence alignment by Florence Corpet.

$<$ http://multalin.toulouse.inra.fr/multalin/>.

\subsubsection{Construção do plasmídeo recombinante de expressão pET28a::CDK13}

Após análise da sequência de nucleotídeos referente à CDK13 e dos sítios de enzimas de restrição presentes nela, foram escolhidos os sítios para as enzimas de restrição $\mathrm{Ndel}$ e Sacl para serem colocadas nas extremidades do fragmento de DNA, caso fosse necessário libera-lo posteriormente. O vetor de expressão escolhido foi o $\mathrm{pET} 28 \mathrm{a}(+)$, o qual possui uma sequência codificante de uma cauda de histidinas, que é utilizada para a purificação da proteína por afinidade, por exemplo, ao $\mathrm{Ni}^{2+}$. O plasmídeo recombinante de 
expressão pET28a::CDK13 possui 8017pb (2703pb da CDK13 e 5314 do vetor) e foi adquirido da empresa EPOCH Life Science.

Uma alíquota de $1 \mu \mathrm{L}$ do plasmídeo $(80 \mathrm{ng} / \mu \mathrm{L})$, foi utilizado para transformação em E. coli. As colônias foram selecionadas pela presença do antibiótico kanamicina $(30 \mu \mathrm{g} / \mathrm{mL})$, ao qual o vetor $\mathrm{pET} 28 \mathrm{a}(+)$ possui resistência. Os plasmídeos recombinantes foram purificados a partir de pré-inóculo. A Figura 22 mostra o produto da purificação.

Figura 22 - Gel de agarose $0,8 \%$ mostrando os plasmídeos recombinantes purificados. 1: Marcador GeneRuler 1Kb DNA Ladder. 2: A partir da colônia I. 3: A partir da colônia II. 4: A partir da colônia III. 5: A partir da colônia IV.

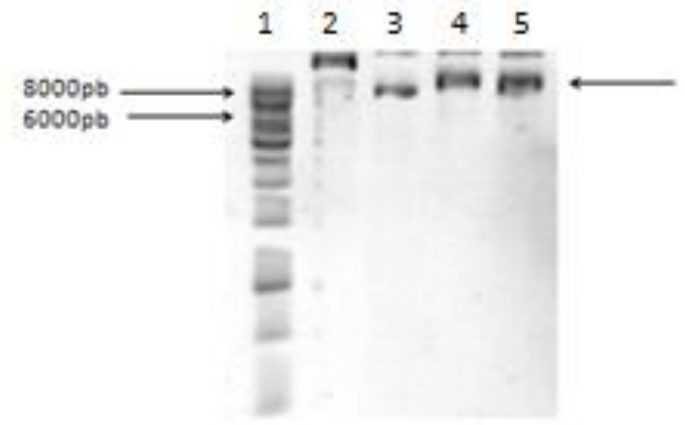

Fonte: Autoria própria.

Observa-se que os plasmídeos das colônias II, III e IV possuem o tamanho esperado, aproximadamente $8000 \mathrm{pb}$. Os plasmídeos obtidos a partir dessas colônias foram utilizados nos testes de expressão.

Apesar de o fornecedor realizar o sequenciamento do DNA sintetizado, novo sequenciamento do plasmídeo recombinante pET28a::CDK13 foi realizado (Figura 23) no Laboratório de Biologia Molecular do Grupo de Cristalografia do IFSC, confirmando a integridade da sequência. 
Figura 23 - Sequenciamento automático do DNA referente à CDK13 sintético. A figura mostra o alinhamento das sequências obtidas nos sequenciamentos realizados a partir das extremidades 5' (a) e 3' (b) do DNA referente a CDK13 humana. Observa-se pela identidade entre as sequências a integridade do DNA recombinante.

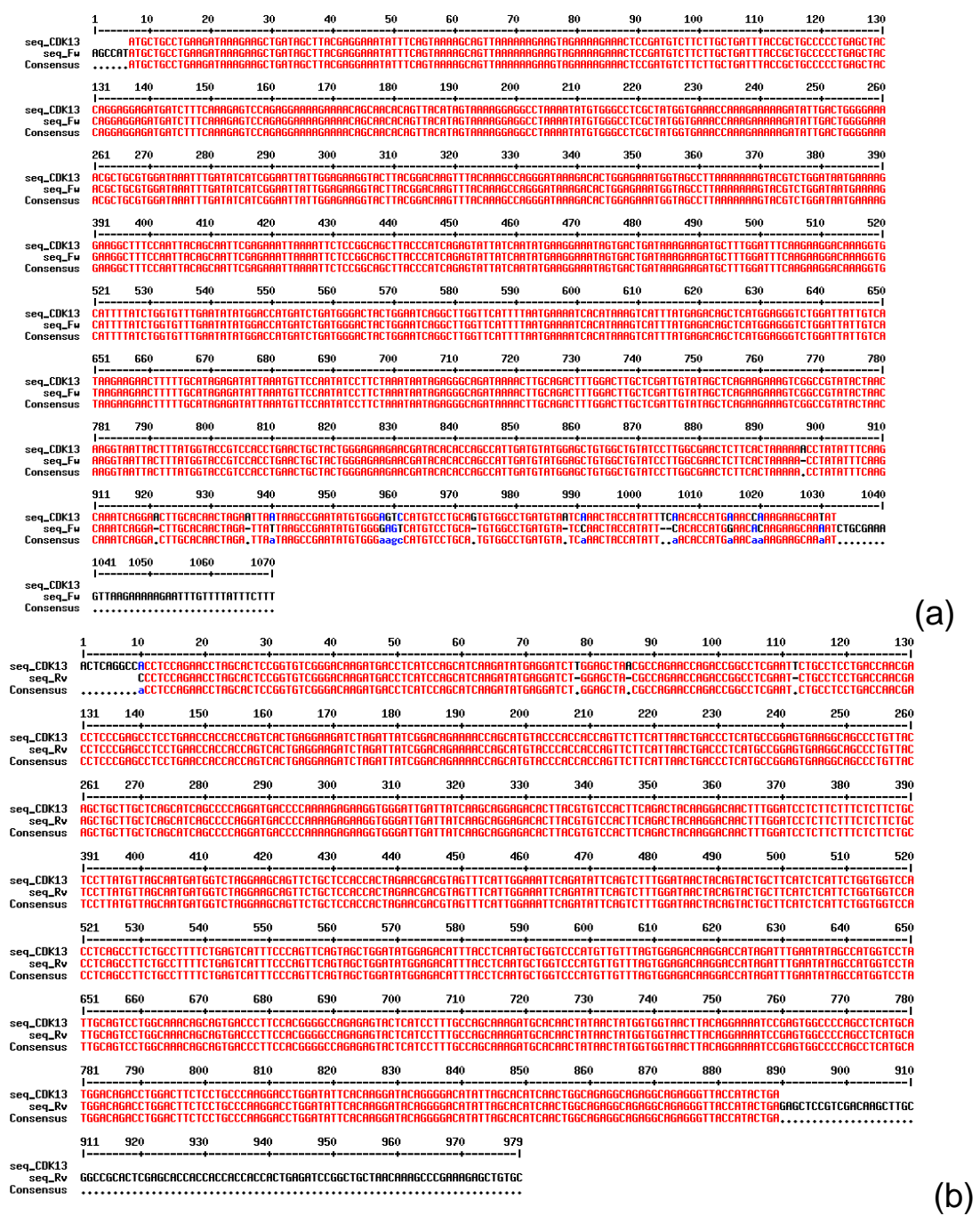

Fonte: Multiple sequence alignment by Florence Corpet. $<$ http://multalin.toulouse.inra.fr/multalin/>.

\subsubsection{Obtenção do plasmídeo recombinante pET28a::CDK13 após modificação}

O plasmídeo pET28a::CDK13 foi modificado a fim de obter apenas a sequência da CDK13 que contém seu sítio ativo, desprezando uma parte final da extremidade $5^{\prime}$, para obter um DNA de $1017 \mathrm{pb}$ e de tamanho de proteína esperado de $38,9 \mathrm{kDa}$ e 339 aminoácidos. Os testes de expressão com o DNA de $2655 \mathrm{pb}$, que corresponde a proteína de $99,7 \mathrm{kDa}$ e 885 aminoácidos 
(sequência depositada no NCBI (GI: 145309302)), estavam resultando em uma proteína truncada de aproximadamente $43 \mathrm{kDa}$, portanto, foi decidido tentar expressar apenas parte da CDK13, correspondente a região que envolve o bolsão de ligação.

Após análise da sequência da CDK13 foram desenhados primers para restringir a região do DNA de interesse durante a amplificação deste DNA juntamente com o vetor $\mathrm{pET} 28 \mathrm{a}(+)$ ao qual ele estava ligado. A Figura 24 mostra o produto da reação de PCR realizado para amplificação de parte da sequência do DNA da CDK13, além da sequência do vetor, a partir do recombinante $\mathrm{pET} 28 \mathrm{a}: \mathrm{:CDK13.}$

Figura 24 - Gel de agarose 0,8\% para análise do produto das reações de PCR com o plasmídeo recombinante pET28a::CDK13 como molde para obter o vetor e parte da sequência da CDK13, para obter um DNA de 1017pb correspondente à CDK13, mais $5369 \mathrm{pb}$ do vetor pET28(+), totalizando um plasmídeo de expressão de 6386pb. 1: Marcador GeneRuler $1 K b$ DNA Ladder. 2 a 6: plasmídeo recombinante de expressão pET28a::CDK13. Temperaturas de anelamento: 75,$0 ; 70,4 ; 60,6 ; 56,5 ; 52,0^{\circ} \mathrm{C}$; respectivamente.

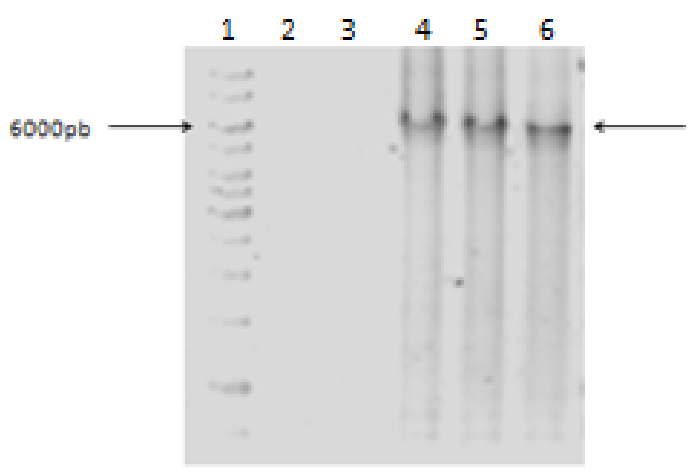

Fonte: Autoria própria.

Uma reação de PCR de $50 \mu \mathrm{L}$ com temperatura de anelamento de $60,6^{\circ} \mathrm{C}$ foi realizada (Figura 25 ), já que a intensidade da banda era forte nesta temperatura indicando uma alta concentração de DNA. A reação foi aplicada em gel de agarose, a partir do qual o DNA foi purificado pelo kit QIAquick Gel Extraction (Qiagen). O plasmídeo recombinante de expressão obtido pela purificação (Figura 25) foi utilizado em testes de expressão. 
Figura 25 - Gel de agarose $0,8 \%$. a) Reação de PCR com temperatura de anelamento $60,6^{\circ} \mathrm{C}$. 1: Marcador GeneRuler 1Kb DNA Ladder. 2: Plasmídeo recombinante de expressão modificado. b) Plasmídeo recombinante de expressão modificado purificado a partir de gel de agarose. 1: Marcador GeneRuler 1Kb DNA Ladder. 2: Plasmídeo recombinante de expressão modificado purificado com o kit QIAquick Gel Extraction (Qiagen).

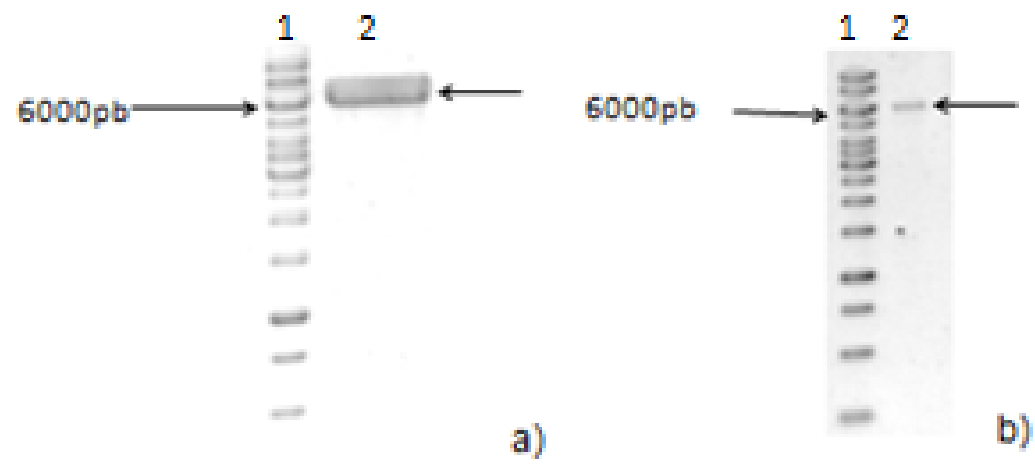

Fonte: Autoria própria.

O plasmídeo sintético modificado foi utilizado para transformação em células de $E$ coli $\mathrm{CaCl}_{2}$ competentes. Reações de PCR de colônia foram feitas para confirmação dos recombinantes. A Figura 26 mostra que nas reações com os primers do vetor é possível observar a presença do DNA da CDK13 em torno de 1400pb. O DNA da CDK13 possui 1017pb, mais a sequência do vetor restringida pelas sequências dos primers T7 de $361 \mathrm{pb}$, totaliza um DNA de 1378pb.

Figura 26 - Gel de agarose 0,8\%. Análise de recombinantes por PCR de colônia. 1: Marcador GeneRuler 1Kb DNA Ladder. 2 a 7: Reações de PCR com primers da CDK13 para as colônias $\underline{a}, \underline{b}, \underline{c}, \underline{d}, \underline{e}$, e $\underline{f}$, respectivamente. 8: Marcador GeneRuler $1 \mathrm{~Kb}$ DNA Ladder. 9 a 14: Reações com primers do vetor para as colônias $\underline{a}, \underline{b}, \underline{c}, \underline{d}$, $\underline{e}$, e $\underline{f}$, respectivamente.

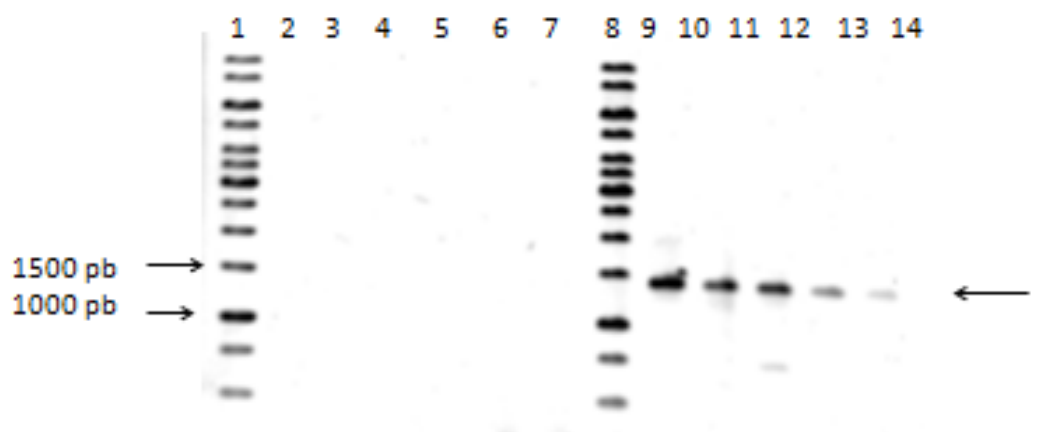

Fonte: Autoria própria. 


\subsection{Expressão}

\subsubsection{Expressão e lise para recuperação da CDK13 obtida com o plasmídeo recombinante pET28a::CDK13 sintético}

A partir da transformação em E. coli BL21(DE3)-CodonPlus-pRIL não cresceram colônias e por isso não foi possível realizar testes de expressão.

A proteína CDK13 não foi expressa nas cepas de $E$. coli BL21(DE3)pLysS e BL21(DE3)pLysE, como mostrado nas Figuras 27 e 28.

Figura 27 - Gel de poliacrilamida $12 \%$ para verificação da expressão da amostra de indução em células BL21(DE3)pLysS, com $0,1 \mathrm{mM}$ de IPTG, a $20^{\circ} \mathrm{C}$ por 15 horas. 1: Marcador Unstained Protein Molecular Weight Marker. 2: Não induzido. 3: Induzido.

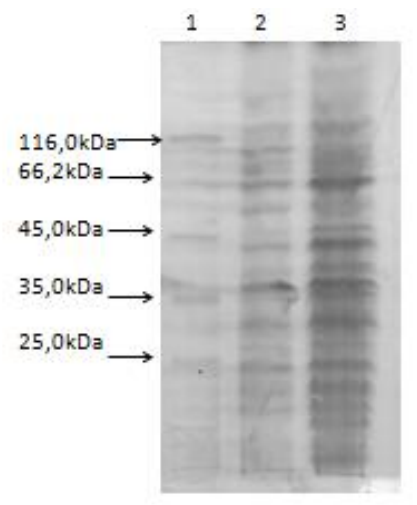

Fonte: Autoria própria.

Figura 28 - Gel de poliacrilamida $12 \%$ para verificação da expressão da amostra de indução em células BL21(DE3)pLysE, com $0,2 \mathrm{mM}$ de IPTG, a $30^{\circ} \mathrm{C}$ por 4 horas. 1: Marcador Unstained Protein Molecular Weight Marker. 2: Não induzido. 3: Induzido (após 1h da adição de IPTG). 4: Induzido (após 2h de indução). 5: Induzido (após 3h de indução). 6: Induzido (após 4h de indução).

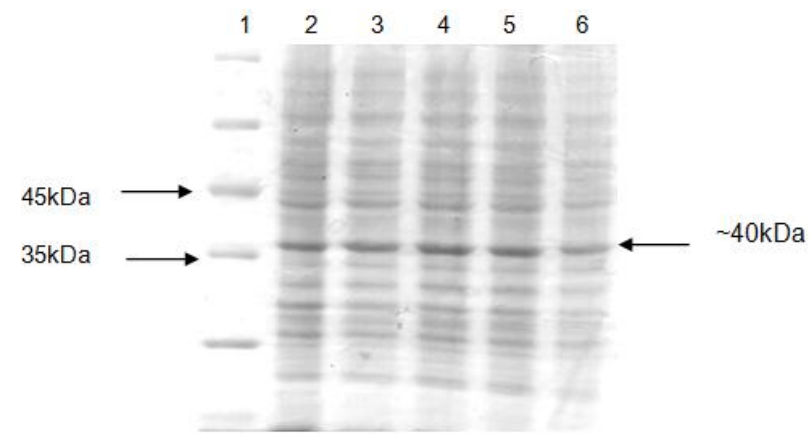

Fonte: Autoria própria. 
Nos testes de expressão em E. coli BL21(DE3) a proteína CDK13 foi expressa, porém em tamanho menor que o esperado, que era de aproximadamente $99 \mathrm{kDa}$, ou seja, apenas parte da proteína foi expressa com um tamanho de aproximadamente $43 \mathrm{kDa}$. A indução foi realizada utilizando $0,1 \mathrm{mM}$ de IPTG, por 4 horas a $30^{\circ} \mathrm{C}$ (Figura 29).

Figura 29 - Gel de poliacrilamida $12 \%$ para verificação da indução em células BL21(DE3) com 0,1 mM de IPTG, a $30^{\circ} \mathrm{C}$, por 4 horas. 1: Marcador Unstained Protein Molecular Weight Marker. 2: Não induzido. 3: Induzido (após 1h da adição de IPTG). 4: Induzido (após 2h de indução). 5: Induzido (após 3h de indução). 6: Induzido (após 4h de indução).

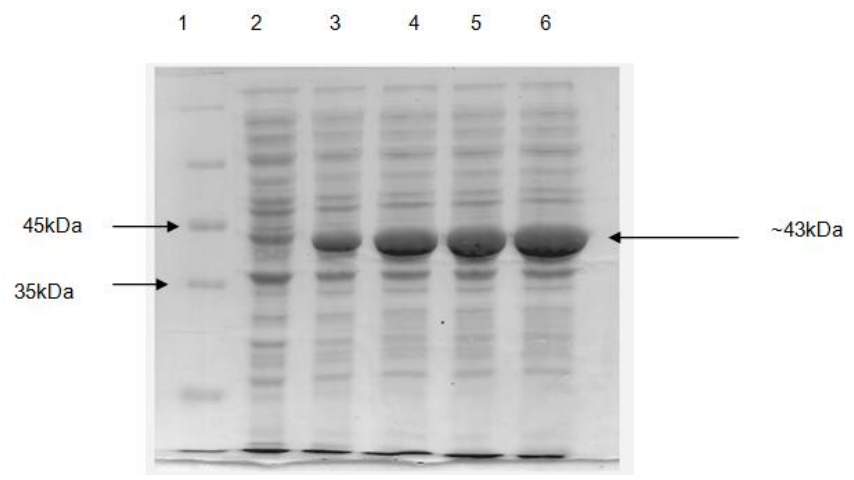

Fonte: Autoria própria.

O experimento foi repetido mais algumas vezes, com 0,1mM de IPTG, por 15 horas a $20^{\circ} \mathrm{C}$, (Figura 30 ) e ainda assim, apenas uma parte da proteína foi expressa.

Figura 30 - Gel de poliacrilamida $12 \%$ da indução em células BL21(DE3) com 0,1mM de IPTG, a $20^{\circ} \mathrm{C}$, por 15 horas. 1: Marcador Unstained Protein Molecular Weight Marker. 2: Não induzido. 3: Induzido, após 15 horas da adição de IPTG.

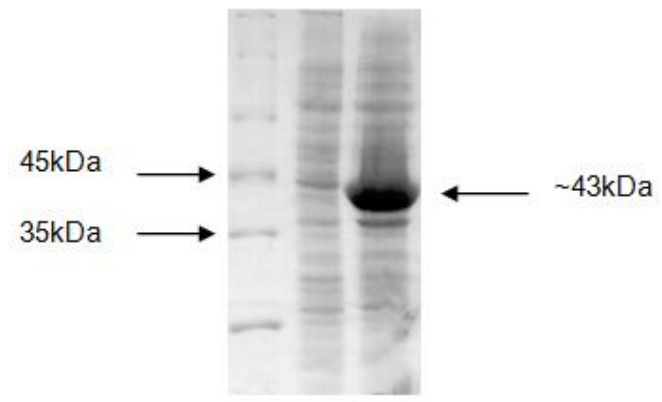

Fonte: Autoria própria. 
Outro teste foi realizado com $0,1 \mathrm{mM}$ de IPTG, por 4 horas a $37^{\circ} \mathrm{C}$ (Figura 31), no qual a proteína não foi expressa.

Figura 31 - Gel de poliacrilamida $12 \%$ da indução em células BL21(DE3) com 0,1mM de IPTG, a $37^{\circ} \mathrm{C}$, por 4 horas. 1: Marcador Unstained Protein Molecular Weight Marker. 2: Não induzido. 3. Induzido por 4 horas.

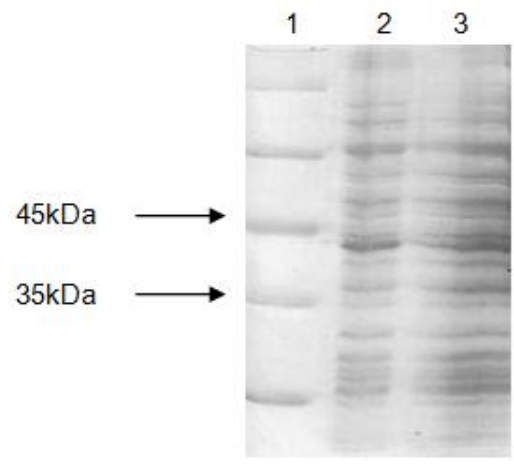

Fonte: Autoria própria.

A expressão em Rosetta(DE3) resultou na expressão de pouca proteína de aproximadamente $43 \mathrm{kDa}$, e uma indução da expressão de uma proteína de pouco menos de 25kDa (Figura 32), entretanto não é possível afirmar que essas proteínas expressas sejam partes da CDK13.

Figura 32 - Gel de poliacrilamida $12 \%$ da indução em células Rosetta(DE3) com $0,2 \mathrm{mM}$ de IPTG, a $20^{\circ} \mathrm{C}$, por 24 horas. 1: Marcador Unstained Protein Molecular Weight Marker. 2: Não induzido. 3: Induzido por 4 horas. Banda 4: Induzido por 24 horas.

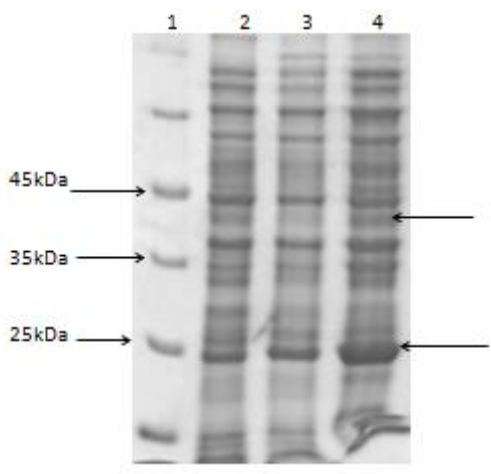

Fonte: Autoria própria.

Foi feita a lise das células após a indução em BL21(DE3) por 4 horas a $30^{\circ} \mathrm{C}$, com 0,1mM de IPTG, com o tampão A (50mM Tris pH8,0,100mM KCl), e observou-se que a proteína estava na fração insolúvel (Figura 33). Outro teste 
de lise foi feito com o tampão $\mathrm{B}(10 \mathrm{mM}$ Tris- $\mathrm{HCl}$ pH7,4, 25mM de $\mathrm{NaCl}$ e $1 \mathrm{mM}$ de EDTA), com 12 ciclos de sonicação, e ainda assim a proteína se encontrou na fração insolúvel (Figura 34). Por isso, e pela proteína ter sido produzida em tamanho menor que o esperado, foi decidido modificar o plasmídeo recombinante de expressão, a fim de obter um plasmídeo de expressão com o DNA correspondente a CDK13 que codificasse a região do bolsão de ligação da CDK13 para se obter uma proteína de aproximadamente 38,9kDa.

Figura 33 - Gel de poliacrilamida $12 \%$ das amostras do teste de lise com o tampão A da amostra de indução em BL21(DE3). 1: Marcador Unstained Protein Molecular Weight Marker. 2: Não induzido. 3: Induzido. 4: Pellet. 5: Sobrenadante.

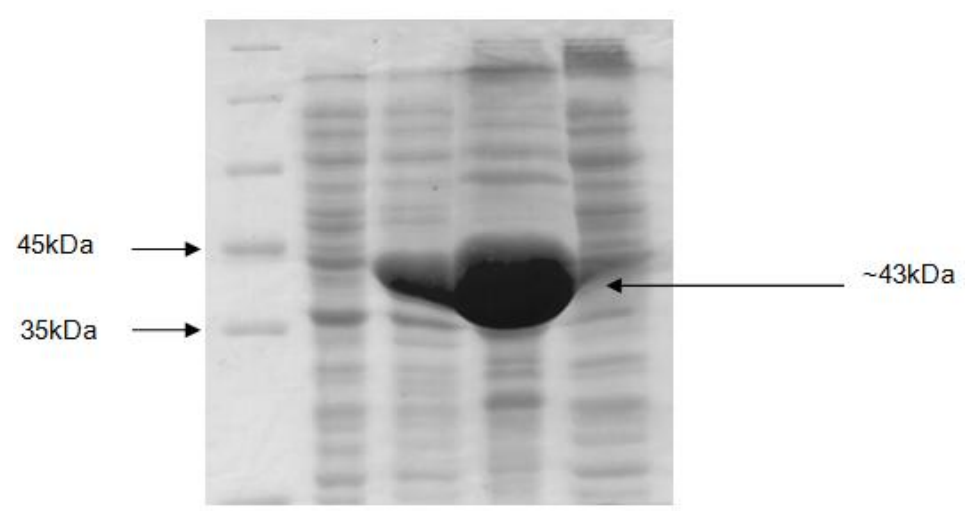

Fonte: Autoria própria. 
Figura 34 - Gel de poliacrilamida $12 \%$ das amostras do teste de lise com o tampão B da amostra de indução em BL21(DE3). 1: Marcador Unstained Protein Molecular Weight Marker. 2: Não induzido. 3: Induzido. 4: Sobrenadante. 5: Pellet.

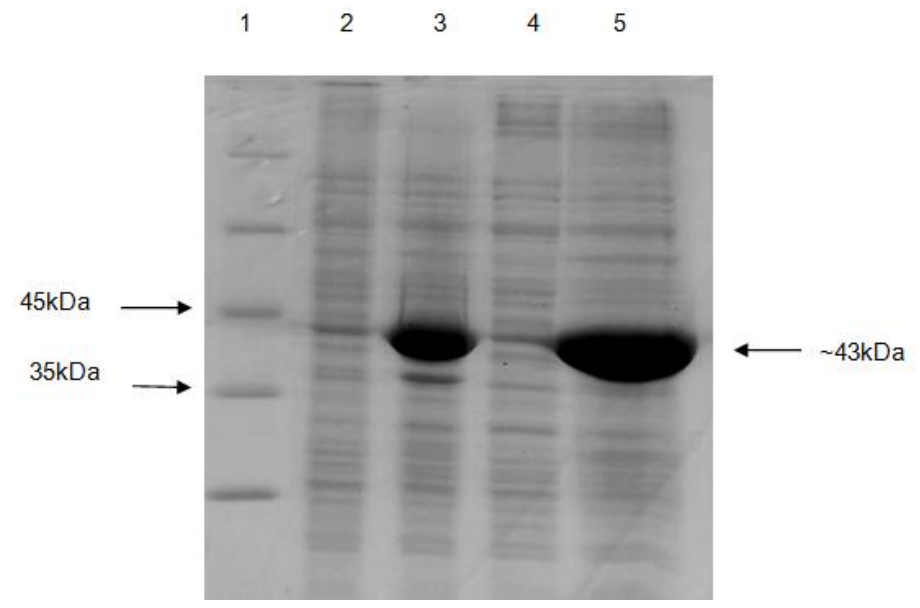

Fonte: Autoria própria.

Os principais resultados obtidos na expressão e lise celular para recuperação da CDK13 utilizando o plasmídeo recombinante pET28a::CDK13 sintético estão na Tabela 15.

Tabela 15 - Principais resultados obtidos na expressão e lise para recuperação da CDK13 utilizando o plasmídeo recombinante pET28a::CDK13 sintético.

\begin{tabular}{c|cc}
\hline Cepa utilizada & \multicolumn{1}{c}{ Resultados obtidos } \\
\hline BL21(DE3) & $\checkmark$ & Proteína de aproximadamente 43kDa. \\
& $\checkmark$ & Indução com 0,1mM de IPTG, a 30º C, por 4 horas. \\
& $\checkmark$ & Maior fração de proteína insolúvel após lise com \\
& tampão A e com tampão B. \\
\hline Rosetta(DE3) & $\checkmark$ & Proteína de aproximadamente 43kDa, e de pouco \\
& $\checkmark$ & menos de 25kDa em baixa concentração. \\
& $\checkmark$ & Indução com 0,2mM de IPTG, a 20C, por 24 horas. \\
\hline
\end{tabular}

\subsubsection{Expressão e lise para recuperação da CDK13 obtida com o plasmídeo recombinante $\mathrm{pET28a::CDK13} \mathrm{sintético} \mathrm{modificado}$}

O plasmídeo de expressão pET28a::CDK13 sintético foi modificado para que fosse expressa a proteína CDK13 com aproximadamente $38,9 \mathrm{kDa}$, região que contém seu bolsão de ligação. 
A partir da comparação da sequência da CDK13 com a de outras CDKs inclusive as que já possuem suas estruturas elucidadas, observou-se que as regiões que participam da ligação ao ATP e ciclina (domínio quinase) e que são importantes para o estudo estrutural ficam na região central. Baseado nestas informações foi possível desprezar parte da região C-terminal e tentar expressar apenas o domínio quinase. A Figura 35 mostra a comparação entre as sequências. ${ }^{68}$

Figura 35 - Alinhamento das sequências do domínio quinase das CDKs, as extensões $\mathrm{N}$ e $\mathrm{C}$ terminais foram excluídas. As regiões mais importantes estão destacadas em caixas verdes, incluindo sítio de ligação do ATP, o domínio de ligação à ciclina (PSTAIRE na CDK1) e os resíduos que marcam o início e final da alça T. Os sítios de regulação por fosforilação estão em caixas roxas e incluem os resíduos de treonina e tirosina no domínio de ligação ao ATP, o resíduo de treonina de ativação na alça T. Os resíduos não conservados estão coloridos em rosa. As sequências das CDKs 13 estão destacadas em amarelo. A amplitude de conservação é representada pela altura das barras pretas abaixo de cada resíduo. As sequências são de CDKs 1, 2 (isoformas $1 \mathrm{e}$ 2), 4, 5, 6, 7, 8, 9, 10 (isoformas 1 e 2), 11, 12 (isoformas 1, 2 e 3), 13 (isoformas 1 e 2), 14, 15, 16, 17, 18, 19 (isoformas 1 e 2) e 20. A primeira lisina da CDK13 corresponde ao resíduo 85 da cadeia e o último corresponde ao resíduo 293 (leucina). 


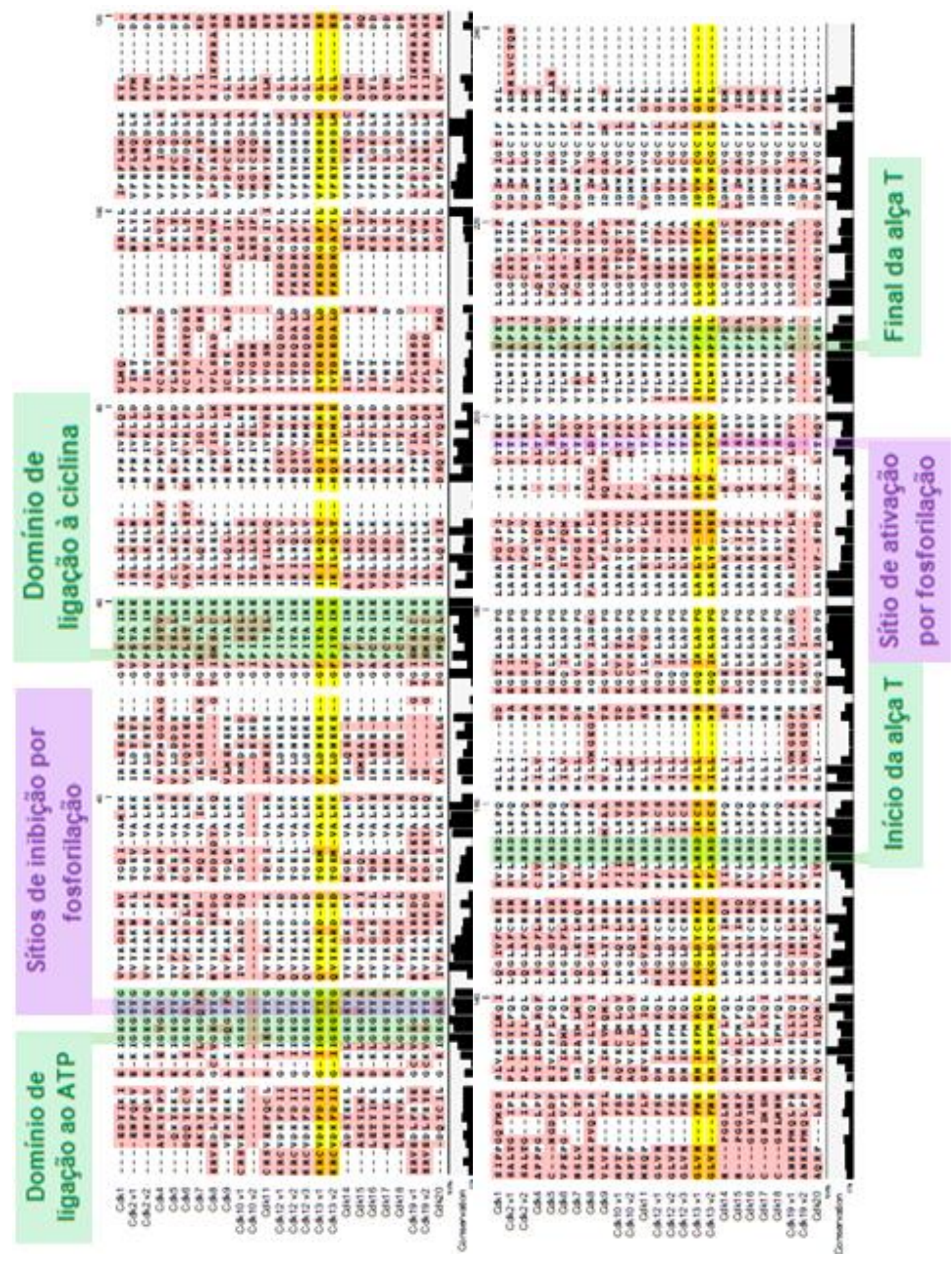

Fonte: Adaptado de LIM, S., 2013, p. $3082 .^{68}$

A partir do alinhamento, mostrado na Figura 36 entre a CDK12 e a CDK13 feito pelo Multalin (Multiple sequence alignment by Florence Corpet. <http://multalin.toulouse.inra.fr/multalin/>) é possível observar os resíduos de aminoácidos mencionados na Figura 37, a primeira lisina da CDK13 que 
corresponde ao resíduo 85 da cadeia polipeptídica e a última leucina que corresponde ao resíduo 293.

Figura 36 - Alinhamento das sequências de aminoácidos da CDK12 e da CDK13. Os resíduos de aminoácidos mencionados na Figura 35, lisina $(K)$ e leucina (L) estão indicados por setas.

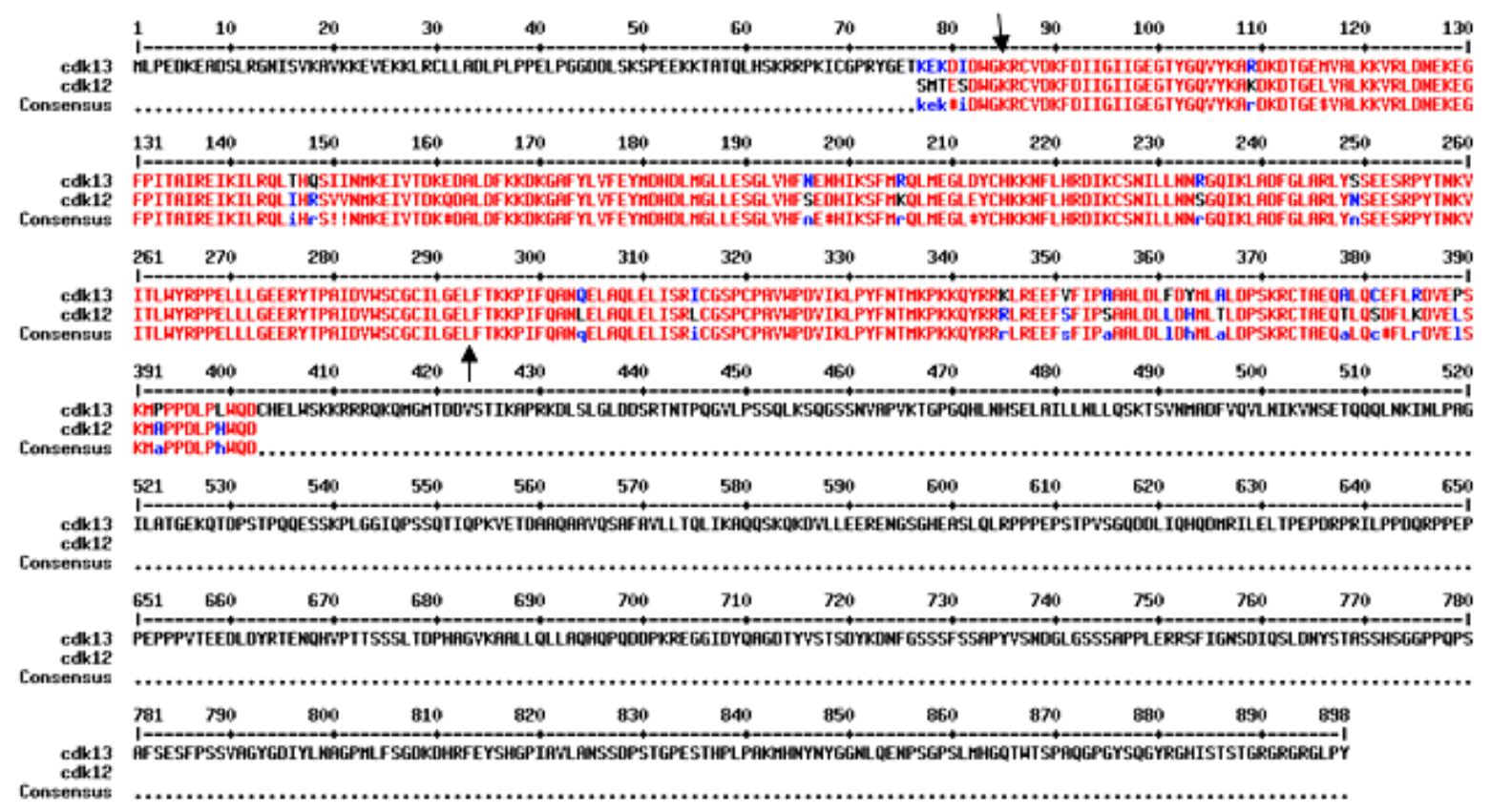

Fonte: Adaptado de Multiple sequence alignment by Florence Corpet. $<$ http://multalin.toulouse.inra.fr/multalin/>.

Foi feita a modelagem para predição da estrutura terciária da proteína CDK13 ( 99kDa, e 1512 aminoácidos) para se observar qual a região do domínio quinasee que poderia ser expressa com maior facilidade pelo sistema bacteriano $E$ coli. A partir de pesquisa no site <http://blast.ncbi.nlm.nih.gov/Blast.cgi?PROGRAM=blastp\&PAGE_TYPE=Blast BlastS\&LINK_LOC=blasthome> foram encontradas as proteínas CDK12 (código PDB: 4CJY C) e CDK9 (código PDB: 3BLH A) como possíveis moldes. A CDK12 tem identidade de $91 \%$ e cobertura de $21 \%$ com a CDK13, e a CDK9 tem identidade de $48 \%$ e cobertura de $20 \%$ com a CDK13. O alinhamento das sequências da CDK13 com a CDK12 e da CDK13 com a CDK9 foram feitas no programa Multalin no site <http://multalin.toulouse.inra.fr/multalin/> e se encontram nas Figuras 36 e 37, respectivamente. 
Figura 37 - Alinhamento das sequências de aminoácidos da CDK9 e da CDK13.

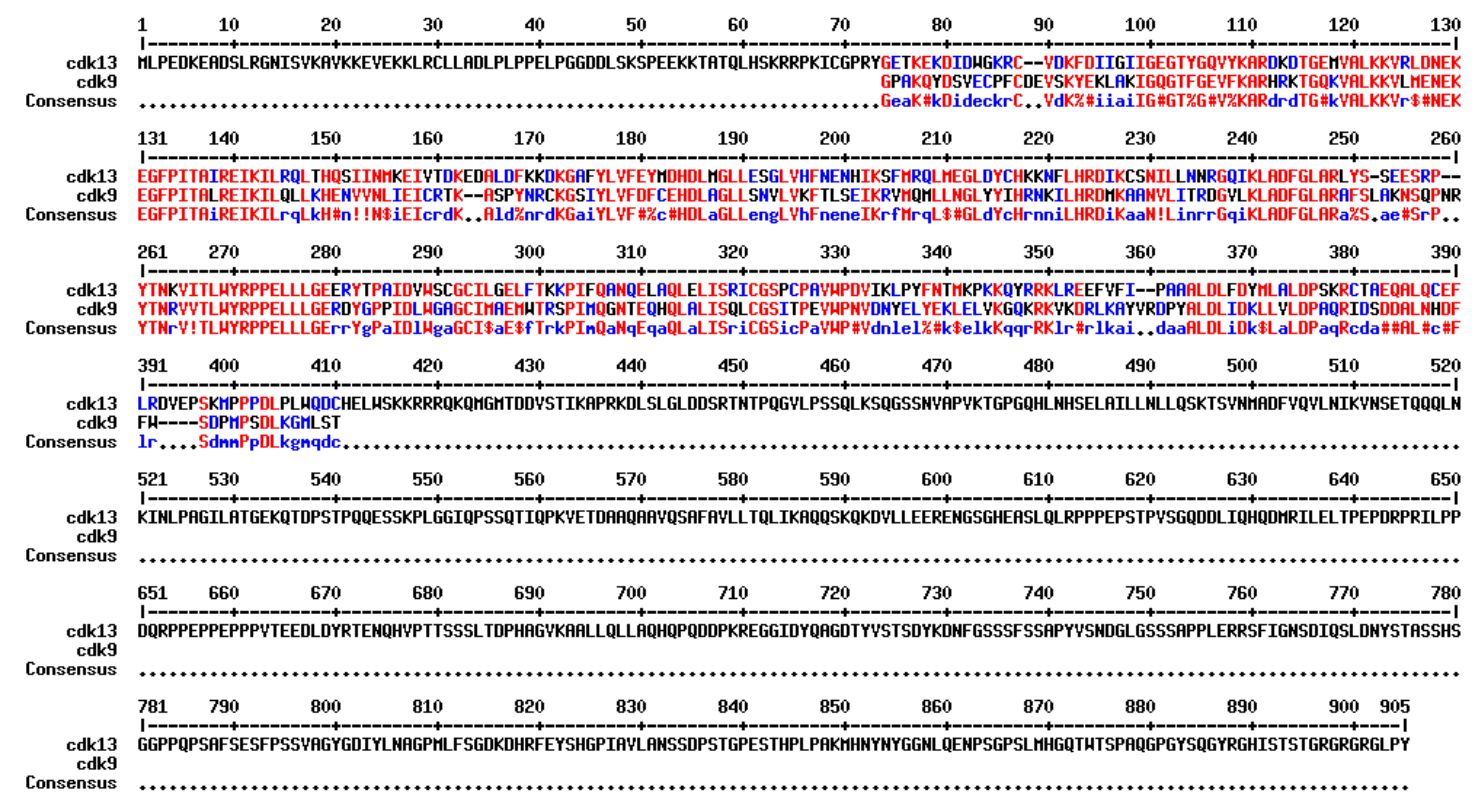

Fonte: Multiple sequence alignment by Florence Corpet. $<$ http://multalin.toulouse.inra.fr/multalin/>.

O alinhamento da CDK13 com a CDK12 (Figura 36) mostra que a identidade é muito alta na região central, e grande parte da região C-terminal não se alinha à CDK12. A partir do alinhamento entre as CDK13 e CDK9 (Figura 37) observa-se que o número de aminoácidos conservados é menor, e por isso a identidade também é mais baixa. Novamente, a porção central tem maior identidade, mas ainda nesta região, na direção $\mathrm{N}$-terminal, o número de aminoácidos conservados é baixo.

A modelagem foi feita pelo programa Swiss-Model do site <http://swissmodel.expasy.org/>. O Swiss-Model é um servidor para modelagem molecular de proteínas por homologia. O programa cumpre as quatro principais etapas da modelagem por homologia: identificação do(s) molde(s), alinhamento da sequência da proteína alvo com o da proteína usada como molde, construção do modelo, e estimativa da qualidade do modelo gerado, sua validação. Cada etapa é repetida até que um modelo satisfatório seja gerado.

A Figura 38 mostra o modelo estrutural da CDK13 obtido a partir da CDK12 como molde. O modelo foi considerado de qualidade baixa pelo 
programa Swiss-Model, provavelmente devido à baixa resolução da estrutura cristalográfica da CDK12 (3,15 ̊̊).

Figura 38 - Modelo estrutural da proteína CDK13 obtido a partir da CDK12 como molde, utilizando modelagem por homologia.

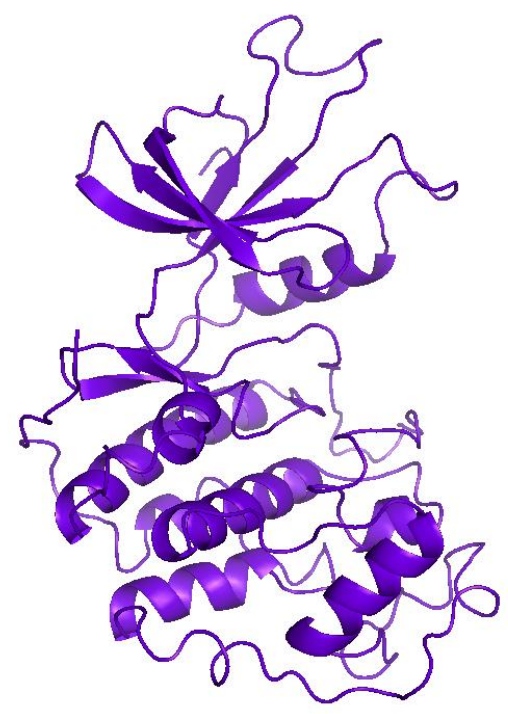

Fonte: Swiss-Model. <http://swissmodel.expasy.org/>.

A Figura 39 apresenta o modelo obtido a partir da CDK9 como molde. A estrutura cristalográfica da CDK9 possui melhor resolução, 2,48 $\AA$, o que aumentou a qualidade do modelo gerado.

Figura 39 - Modelo estrutural da proteína CDK13 obtido a partir da CDK9 como molde, utilizando modelagem por homologia.

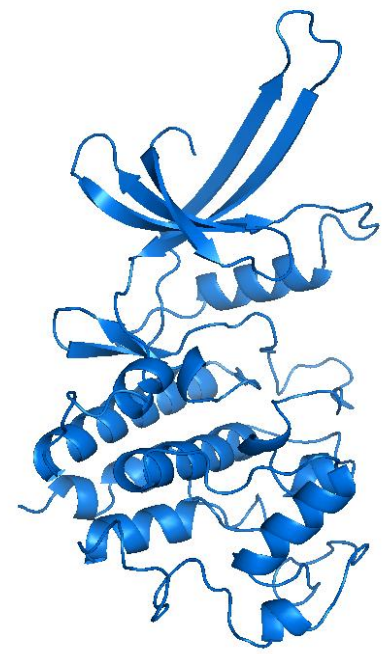

Fonte: Swiss-Model. <http://swissmodel.expasy.org/>. 
Em ambos os modelos observa-se a estrutura típica de CDKs com um domínio $\mathrm{N}$-terminal rico em folhas $\beta$ e um domínio C-terminal com predominância de hélices- $\alpha$. As estruturas da CDK9 e CDK12 utilizados são dos seus domínios quinases, os quais foram expressos e utilizados para resolução cristalográfica por difração de raios $X$. Os domínios quinases se alinharam ao domínio quinase da CDK13, possibilitando a geração dos modelos estruturais. E a partir desses resultados foi decidido modificar 0 plasmídeo sintético para expressar o domínio quinase da CDK13, o qual despreza parte da região C-terminal.

A Figura 40 mostra a sequência de aminoácidos da CDK13 a ser expressa pelo plasmídeo sintético modificado.

Figura 40 - Sequência de aminoácidos em código de uma letra da proteína CDK13 a ser expressa pelo plasmídeo sintético modificado. O primeiro resíduo de aminoácido metionina corresponde a metionina corresponde ao resíduo 1 da sequência polipeptídica da CDK13, e a última lisina corresponde ao resíduo 339 da CDK13.

\section{MLPEDKEADSLRGNISVKAVKKEVEKKLRCLLADLPLP PELPGGDDLSKS PEEKKTATQL HSKRRPKICGPRYGETKEKDI DWGKRCVDKFDI I GI I GEGTYGQVYKARDKDTGEMVALK KVRLDNEKEGFPITAIREIKILRQLTHQS I INMKE IVTDKEDALDFKKDKGAFYLVFEYM DHDLMGLLESGLVHFNENH I KSFMRQLMEGLDYCHKKNFLHRD I KCSN I LLNNRGQ I KLA DFGLARLYSSEESRPYTNKVITLWYRPPELLLGEERYTPAIDVWSCGCILGELFTKKPIF QANQELAQLELISRICGSPCPAVWPDVIKLPYFNTMKPK}

Fonte: Adaptado de Protein Database. <http://www.ncbi.nlm.nih.gov/>. referência:NP_003709.3.

Os testes de expressão foram realizados nas cepas BL21(DE3), que é deficiente em proteases, BL21(DE3)pTGroE, a qual contém chaperoninas que poderiam auxiliar no enovelamento na estrutura nativa da CDK13, na Origami(DE3) que facilita a formação das ligações dissulfeto e em Rosetta(DE3) que contém tRNAs para códons raros em E. coli.

As cepas pLysS e pLysE não foram testadas, pois nos testes com 0 plasmídeo recombinante de expressão pET28a::CDK13 sintético a proteína CDK13 não foi expressa. Colônias não cresceram após transformação com a BL21(DE3)-CodonPlus-pRIL, e como ela possui tRNAs para códons raros em E. coli, assim como a Rosetta(DE3), a última foi escolhida para fazer os experimentos. 
A proteína não foi expressa na BL21(DE3)pTGroE e Origami(DE3) (Figuras 41 e 42).

Figura 41 - Gel de poliacrilamida 12\% da indução em células BL21(DE3)pTGroE com $0,2 \mathrm{mM}$ de IPTG, a $30^{\circ} \mathrm{C}$, por 15 horas. 1: Marcador Unstained Protein Molecular Weight Marker. 2: Não induzido. 3: Induzido.

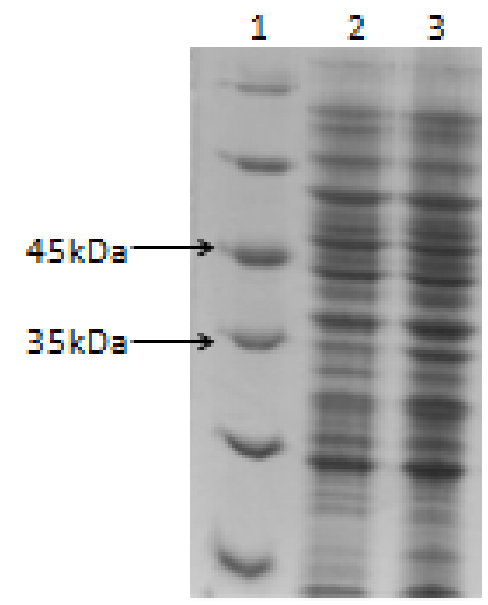

Fonte: Autoria própria.

Figura 42 - Gel de poliacrilamida $12 \%$ da indução em células Origami(DE3) com $0,2 \mathrm{mM}$ de IPTG, a $30^{\circ} \mathrm{C}$, por 15 horas. 1: Marcador Unstained Protein Molecular Weight Marker. 2: Não induzido. 3: Induzido.

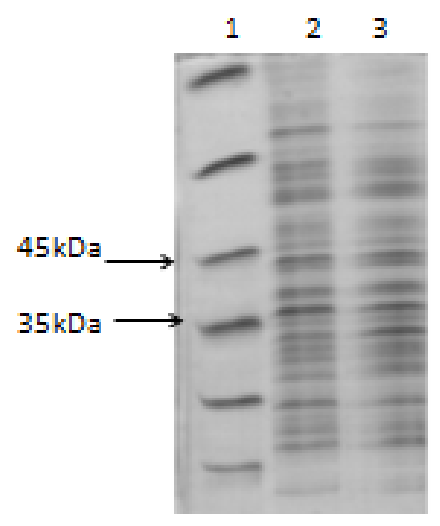

Fonte: Autoria própria.

Nas cepas BL21(DE3) e Rosetta(DE3), a proteína foi expressa (Figura 43), porém em pouca quantidade. Foram feitos testes de indução com 0,2mM de IPTG a $30^{\circ} \mathrm{C}$ por 4 horas, e 0,2mM de IPTG a $20^{\circ} \mathrm{C}$ por 15 horas, nas duas cepas. Como a quantidade de proteína expressa foi um pouco maior em Rosetta(DE3), foram feitos testes de indução com 0,2; 0,4; 0,6 e 0,8mM de IPTG a $20^{\circ} \mathrm{C}$ por 15 horas (Figura 44), pois uma quantidade maior de IPTG 
pode aumentar a quantidade de proteína expressa, e uma temperatura menor pode ajudar no enovelamento correto da proteína por diminuir a velocidade da expressão. Foi observado que a concentração de IPTG não influenciou na quantidade de proteína expressa, e, portanto, os próximos experimentos foram feitos com 0,2mM de IPTG. Uma proteína de menos de 25kDa também foi expressa, porém, outros experimentos foram necessários para analisar se era a CDK13.

Figura 43 - Gel de poliacrilamida $12 \%$ da indução em células Rosetta(DE3) e BL21(DE3) com $0,2 \mathrm{mM}$ ou $0,4 \mathrm{mM}$ de IPTG, a $20^{\circ} \mathrm{C}$, por 15 horas. 1: Marcador Unstained Protein Molecular Weight Marker. 2: Não induzido, células Rosetta(DE3). 3: Induzido, células Rosetta(DE3), 0,2mM de IPTG. 4: Não induzido, células Rosetta(DE3). 5: Induzido, células Rosetta(DE3), 0,4mM de IPTG. 6: Não induzido, células BL21(DE3). 7: Induzido, células BL21(DE3), 0,2mM de IPTG.

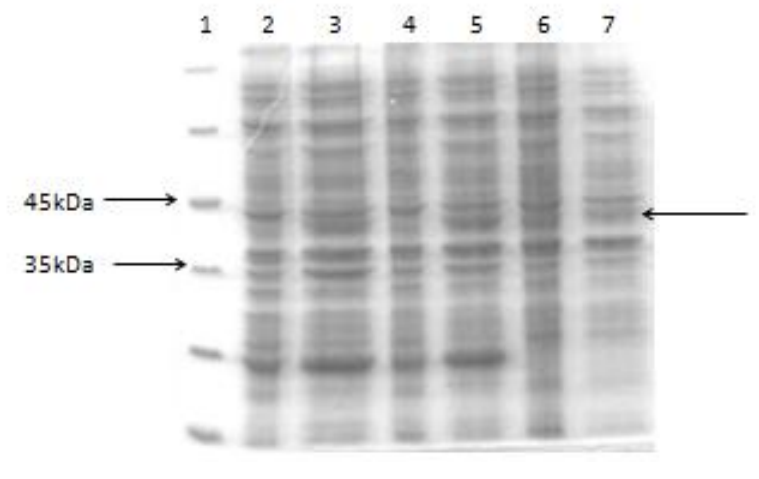

Fonte: Autoria própria. 
Figura 44 - Gel de poliacrilamida $12 \%$ da indução em células Rosetta(DE3) a $20^{\circ} \mathrm{C}$, por 15 horas. 1: Marcador Unstained Protein Molecular Weight Marker. 2: Não induzido. 3: Induzido, 0,8mM de IPTG. 4: Não induzido. 5: Induzido, 0,6mM de IPTG. 6: Não induzido. 7: Induzido, 0,4mM de IPTG. 8: Não induzido. 9: Induzido, 0,2mM de IPTG.

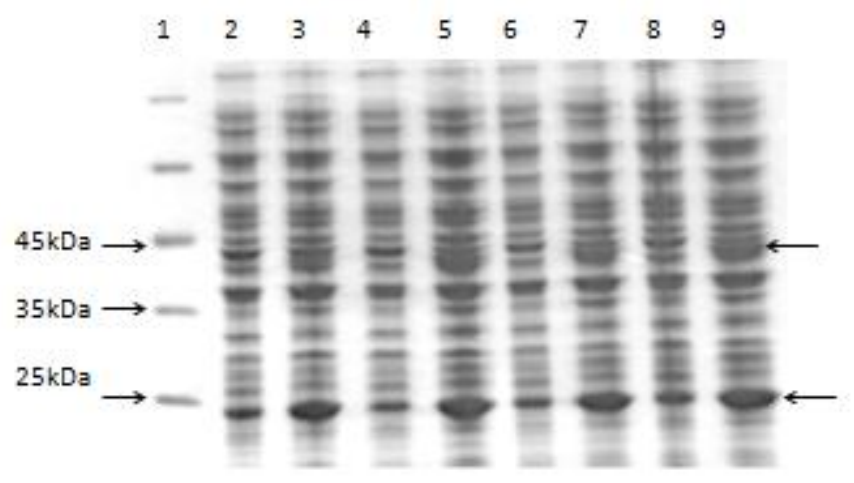

Fonte: Autoria própria.

Como a quantidade de proteína expressa foi um pouco maior em Rosetta(DE3), esta cepa foi escolhida para fazer uma expressão em $500 \mathrm{~mL}$ de meio LB para posterior lise das células. O tampão D (50mM Tris pH 8,0, $300 \mathrm{mM} \mathrm{KCl,5mM} \mathrm{DTT,} \mathrm{5 \%} \mathrm{glicerol)} \mathrm{foi} \mathrm{utilizado,} \mathrm{já} \mathrm{que} \mathrm{este} \mathrm{é} \mathrm{o} \mathrm{tampão} \mathrm{mais}$ indicado para posterior purificação em coluna de $\mathrm{Ni}^{2+}$. Após a lise, observou-se que uma fração da proteína encontrava-se solúvel (sobrenadante) (Figura 45).

Figura 45 - Gel de poliacrilamida $12 \%$ da lise celular da indução em Rosetta(DE3) com $0,2 \mathrm{mM}$ de IPTG, a $20^{\circ} \mathrm{C}$, por 15 horas. 1: Marcador Unstained Protein Molecular Weight Marker. 2: Não induzido. 3: Induzido. 4: Sobrenadante. 5: Pellet.

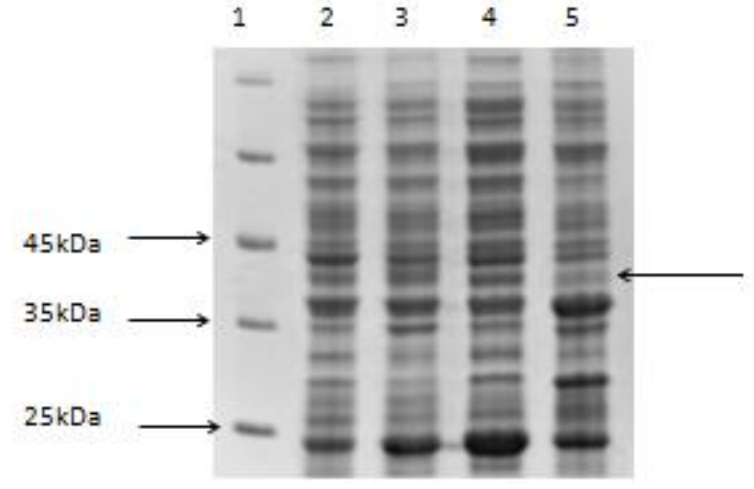

Fonte: Autoria própria.

A fim de tentar aumentar a quantidade de proteína na fração solúvel, foi feito um teste de lise por "freezing and thawing" com o tampão C (20mM Tris, 
$250 \mathrm{mM} \mathrm{KCl}, 10 \%$ glicerol), com o resultado mostrado na Figura 46. Porém, este método de lise não foi mais eficiente do que o de lise química e física.

Figura 46 - Gel de poliacrilamida $12 \%$ da lise celular por "freezing and thawing" da indução em células Rosetta(DE3) com $0,2 \mathrm{mM}$ de IPTG, a $20^{\circ} \mathrm{C}$, por 15 horas. 1: Marcador Unstained Protein Molecular Weight Marker. 2: Sobrenadante. 3: Pellet.

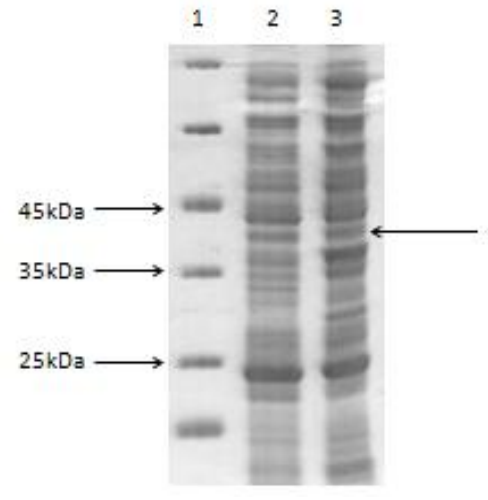

Fonte: Autoria própria.

A Tabela 16 mostra os principais resultados obtidos na expressão e lise celular para recuperação da CDK13 obtida utilizando o plasmídeo recombinante pET28a::CDK13 sintético modificado.

Tabela 16 - principais resultados obtidos na expressão e lise celular para recuperação da CDK13 obtida utilizando o plasmídeo recombinante pET28a::CDK13 sintético modificado.

\begin{tabular}{c|cl}
\hline Condições experimentais & \multicolumn{1}{c}{ Resultados obtidos } \\
\hline Rosetta(DE3) & $\checkmark$ & Proteína de aproximadamente 39kDa. \\
Indução com $0,2 \mathrm{mM}$ de IPTG, a & $\checkmark$ & Proteína na fração solúvel após lise \\
$20^{\circ} \mathrm{C}$, por 15 horas. & & $\begin{array}{l}\text { com tampão D, possibilitando a } \\
\text { purificação em coluna de níquel. }\end{array}$ \\
\hline
\end{tabular}

\subsubsection{Expressão e lise para recuperação da CDK13 obtida com o plasmídeo recombinante pET28a::CDK13 sintético e sintético modificado, em meio de auto-indução}

O meio de auto-indução foi utilizado para testar a possibilidade de se obter maior quantidade de proteína expressa e solúvel. 
O teste em meio de auto-indução com o plasmídeo sintético resultou na expressão de parte da proteína, provavelmente de seu N-terminal, por se ligar à coluna de afinidade ao níquel e a cauda de histidina estar localizada no seu $\mathrm{N}$-terminal (Figura 47). No meio de auto-indução foi obtida quantidade maior de proteína em comparação a obtida utilizando meio LB.

Já no caso dos testes de expressão do plasmídeo sintético modificado tanto utilizando meio LB, quanto meio de auto-indução, resultaram em baixa concentração da proteína de $39 \mathrm{kDa}$ (Figura 48).

A partir dos resultados de expressão em meio de auto-indução, a expressão utilizando $500 \mathrm{~mL}$ de meio foi realizada com as amostras de plasmídeo sintético. Foi feita a lise celular com o tampão D (50mM Tris pH 8,0, $300 \mathrm{mM} \mathrm{KCl}, 5 \mathrm{mM}$ DTT, $5 \%$ glicerol) para purificação em coluna de afinidade ao $\mathrm{Ni}^{2+}$ e uma outra amostra (Figura 49), com o tampão E (10mM Hepes pH7,4, $25 \mathrm{mM} \mathrm{NaCl}, 1 \mathrm{mM}$ EDTA, $10 \%$ glicerol (v/v) e 0,5mM DTT) para purificação em coluna de afinidade ao ATP.

Figura 47: Gel de poliacrilamida $12 \%$ da indução em células Rosetta(DE3), transformação com plasmídeo sintético com $0,2 \mathrm{mM}$ de IPTG, a $20^{\circ} \mathrm{C}$, por 72 horas. 1: Marcador Unstained Protein Molecular Weight Marker. 2: Controle (células de Rosetta(DE3) sem transformação). 3: Não induzido. 4: Induzido.

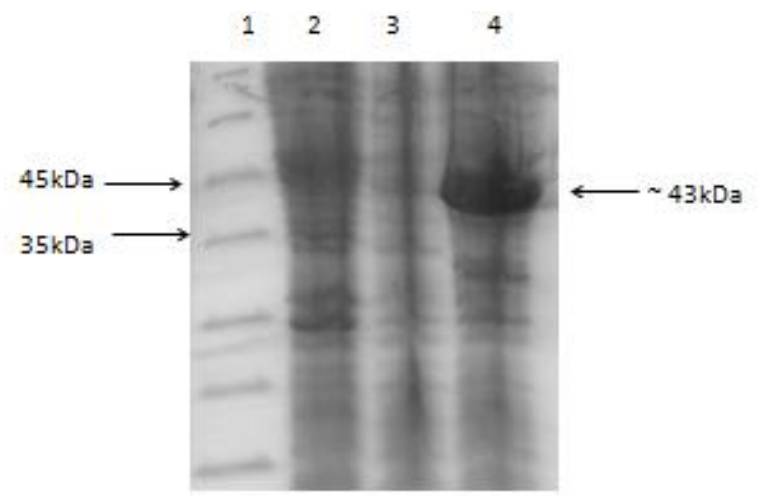

Fonte: Autoria própria. 
Figura 48 - Gel de poliacrilamida $12 \%$ da indução em células Rosetta(DE3), transformação com plasmídeo sintético modificado com $0,2 \mathrm{mM}$ de IPTG, a $20^{\circ} \mathrm{C}$, por 72 horas. 1: Marcador Unstained Protein Molecular Weight Marker. 2: Não induzido. 3: Induzido.

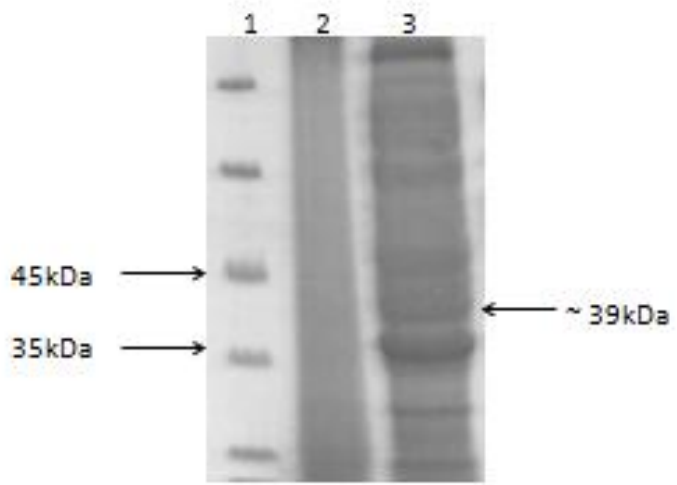

Fonte: Autoria própria.

Figura 49 - Gel de poliacrilamida $12 \%$ da lise de células Rosetta(DE3), transformação com plasmídeo sintético, indução com $0,2 \mathrm{mM}$ de IPTG, a $20^{\circ} \mathrm{C}$, por 72 horas. 1 : Marcador Unstained Protein Molecular Weight Marker. 2: Pellet. 3: Sobrenadante.

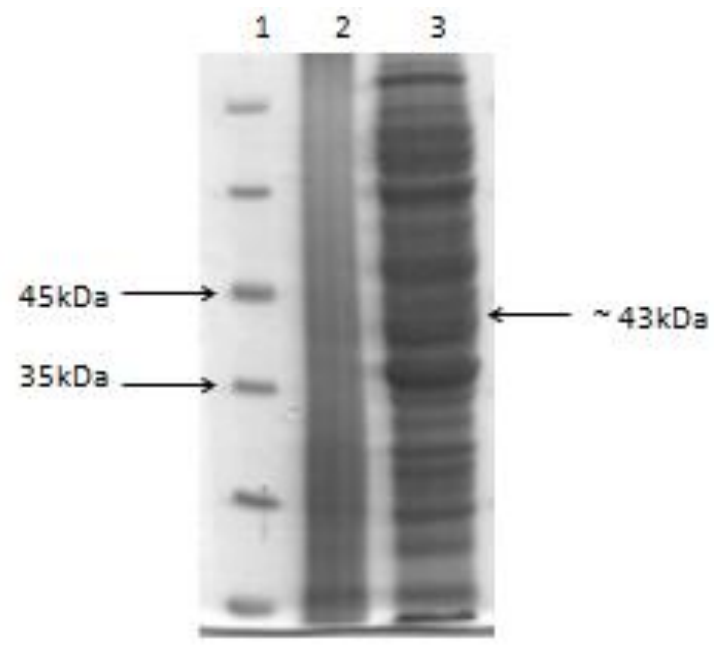

Fonte: Autoria própria.

Os principais resultados obtidos da expressão e lise celular para recuperação da CDK13 obtida com o plasmídeo recombinante pET28a::CDK13 sintético e o modificado em meio de auto-indução estão na Tabela 17. 
Tabela 17 - Principais resultados obtidos da expressão e lise celular para recuperação da CDK13 obtida com o plasmídeo recombinante pET28a::CDK13 sintético e o modificado em meio de auto-indução.

\begin{tabular}{|c|c|}
\hline Condições experimentais & Resultados \\
\hline $\begin{array}{c}\text { Rosetta(DE3) transformada com } \\
\text { plasmídeo sintético } \\
\text { Indução com 0,2mM de IPTG, a } 20^{\circ} \mathrm{C} \text {, por } \\
72 \text { horas }\end{array}$ & $\begin{array}{l}\checkmark \text { Proteína de aproximadamente } \\
43 \mathrm{kDa} \text {. } \\
\checkmark \text { Proteína na fração solúvel após } \\
\text { lise com tampão D e com tampão } \\
\text { E, possibilitando a purificação }\end{array}$ \\
\hline $\begin{array}{c}\text { Rosetta(DE3) transformada com } \\
\text { plasmídeo modificado } \\
\text { Indução com } 0,2 \mathrm{mM} \text { de IPTG, a } 20^{\circ} \mathrm{C} \text {, } \\
\text { por } 72 \text { horas }\end{array}$ & $\begin{array}{l}\checkmark \text { Proteína de aproximadamente } \\
39 \mathrm{kDa} \text {, porém em pouca } \\
\text { quantidade. }\end{array}$ \\
\hline
\end{tabular}

\subsection{Purificação}

\subsubsection{Purificação da CDK13 da expressão em meio LB com plasmídeo sintético modificado}

A fração solúvel (sobrenadante) obtida a partir da expressão em Rosetta(DE3) do plasmídeo sintético modificado, foi obtida a partir da indução a $20^{\circ} \mathrm{C}$ por 15 horas e $0,2 \mathrm{mM}$ de IPTG, e a lise celular foi realizada pelo método físico e químico utilizando o tampão $D$. A amostra foi submetida à purificação em coluna de afinidade ao $\mathrm{Ni}^{2+}$, e o resultado está apresentado na Figura 50, na qual se observa que a proteína não se ligou à coluna. 
Figura 50 - Gel de poliacrilamida $12 \%$ para análise da purificação em coluna de $\mathrm{Ni}^{2+}$. 1 : Marcador Unstained Protein Molecular Weight Marker. 2: Passagem do sobrenadante pela coluna (proteína total). 3: Lavagem com tampão de lise. 4: Eluição com solução de imidazol 20mM em tampão de lise, 5: Eluição com imidazol 50mM, 6: Eluição com imidazol 250mM. 7: Eluição com imidazol 500mM. 8: Lavagem com tampão de lise.

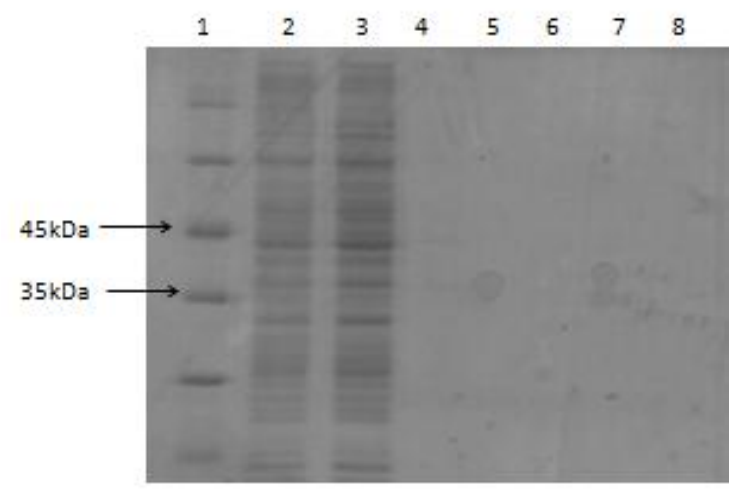

Fonte: Autoria própria.

\subsubsection{Purificação da CDK13 da expressão em meio de auto-indução com plasmídeo sintético}

A fração sobrenadante da expressão com o plasmídeo sintético em Rosetta(DE3) em meio de auto-indução (indução a $20^{\circ} \mathrm{C}$ por 72 horas e $0,2 \mathrm{mM}$ de IPTG) e lise com o tampão $D$ foi submetida à purificação em coluna de afinidade ao $\mathrm{Ni}^{2+}$. A Figura 51 mostra que a proteína se ligou à coluna, e que as eluições com solução de imidazol 20 e 50mM liberou a proteína da coluna, porém em baixa concentração.

A partir do gel da Figura 51 se observa que foi expressa também uma proteína de aproximadamente $100 \mathrm{kDa}$, sendo que a CDK13 possui 99,7kDa, sendo portanto, correspondente à proteína inteira codificada pelo plasmídeo sintético. Isso indica que o meio de auto-indução, por permitir a produção da proteína de forma lenta num tempo estendido, pode ter colaborado para o aumento da fração solúvel, mesmo da proteína de alta massa molecular (proteína inteira). Para identificação da CDK13 neste último teste de expressão, foi feita a análise por Western Blot. 
Figura 51 - Gel de poliacrilamida $12 \%$ mostrando os produtos de expressão em meio de auto-indução durante a purificação em coluna de $\mathrm{Ni}^{2+}$. 1: Marcador Unstained Protein Molecular Weight Marker. 2: Induzido. 3: Sobrenadante após a lise celular. 4: Passagem do sobrenadante pela coluna de afinidade (proteína total). 5: Lavagem com tampão de lise. 6: Eluição com solução de imidazol 20mM, 7: Eluição com imidazol 50mM, 8: Eluição com imidazol 250mM. 9: Eluição com imidazol 500mM. 10: Lavagem com tampão de lise.

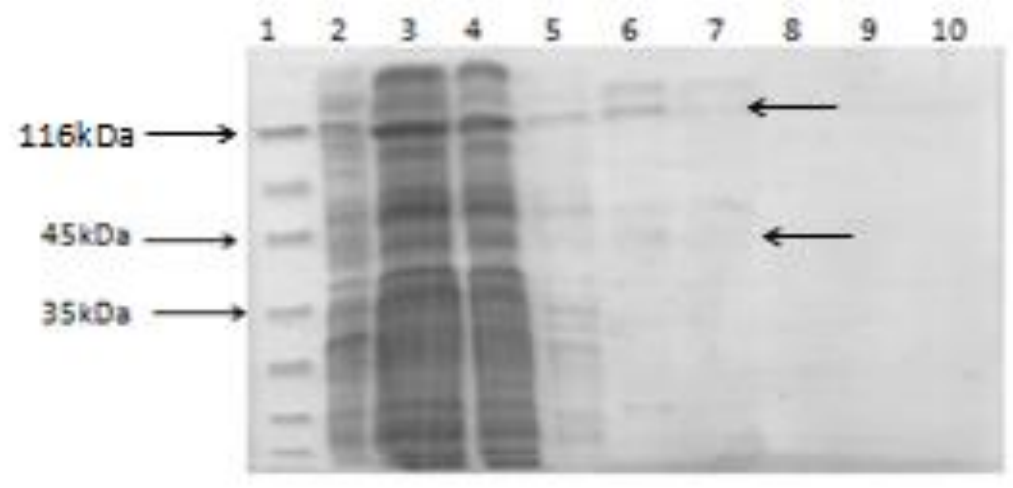

Fonte: Autoria própria.

Uma amostra da fração solúvel obtida na condição anterior foi submetida à purificação em coluna de afinidade ao ATP. Para tanto, foi utilizado o tampão E na lise celular e o extrato bruto foi submetido à purificação. Na presença da CDK13 como produto da expressão, espera-se a ligação à coluna devido a presença do ATP, seu ligante natural.

Na Figura 52 se observa que a proteína não se ligou de forma específica à coluna, como se esperava. Foi observado que houve a eluição de uma pequena fração na presença de $\mathrm{NaCl} 100 \mathrm{mM}$, o que indica que grande parte da proteína possa estar desenovelada e inativa. Outra questão que deve ser considerada é a pré-extração da amostra para então submetê-la a coluna de afinidade. Isso pode ter dificultado a purificação. 
Figura 52 - Gel de poliacrilamida $12 \%$ mostrando os produtos de expressão em meio de auto-indução durante a purificação em coluna de ATP. 1: Marcador Unstained Protein Molecular Weight Marker. 2: Induzido. 3: Sobrenadante. 4: Passagem do sobrenadante pela coluna (proteína total). 5: Lavagem com tampão de lise. 6: Eluição com solução de $\mathrm{NaCl} 50 \mathrm{mM}$, 7: Eluição com $\mathrm{NaCl} 100 \mathrm{mM}$, 8: Eluição com NaCl 250mM. 9: Eluição com NaCl 500mM. 10: Lavagem com tampão de lise.

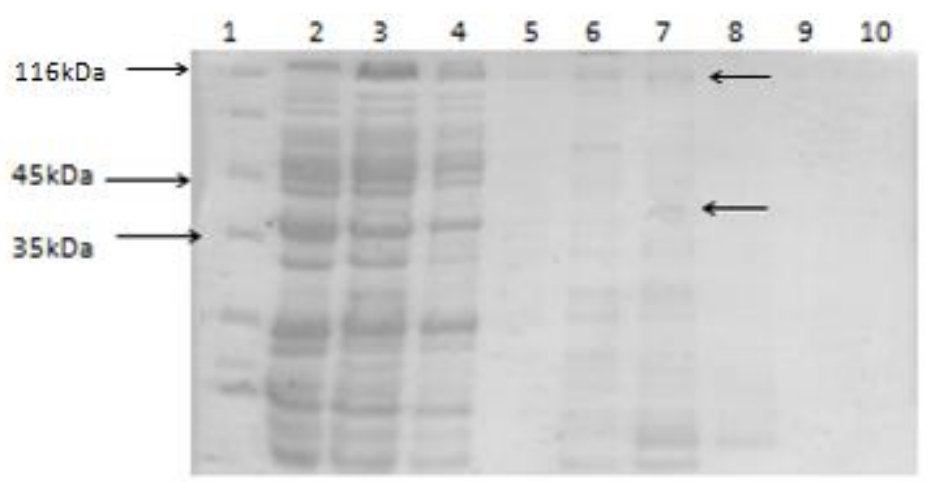

Fonte: Autoria própria.

Os principais resultados para os experimentos de purificação da proteína CDK13 estão na Tabela 18. 
Tabela 18 - Principais resultados dos experimentos de purificação da proteína CDK13.

\begin{tabular}{|c|c|}
\hline Condições experimentais & Resultados obtidos \\
\hline $\begin{array}{l}\text { Rosetta (DE3) transformada com } \\
\text { plasmídeo modificado } \\
\text { Expressão em meio LB e indução com } \\
0,2 \mathrm{mM} \text { de IPTG, a } 20^{\circ} \mathrm{C} \text {, por } 15 \text { horas } \\
\text { Lise celular com tampão D }\end{array}$ & $\begin{array}{l}\checkmark \text { Proteína não se ligou à coluna de } \\
\text { afinidade ao níquel. }\end{array}$ \\
\hline $\begin{array}{c}\text { Rosetta(DE3) transformada com } \\
\text { plasmídeo modificado } \\
\text { Expressão em meio de auto-indução e } \\
\text { indução com } 0,2 \mathrm{mM} \text { de IPTG, a } 20^{\circ} \mathrm{C} \text {, por } \\
72 \text { horas } \\
\text { Lise celular com tampão D }\end{array}$ & $\begin{array}{l}\checkmark \text { Proteína não se ligou à coluna de } \\
\text { afinidade ao níquel }\end{array}$ \\
\hline $\begin{array}{l}\text { Rosetta(DE3) transformada com } \\
\text { plasmídeo sintético } \\
\text { Expressão em meio de auto-indução e } \\
\text { indução com } 0,2 \mathrm{mM} \text { de IPTG, a } 20^{\circ} \mathrm{C} \text {, por } \\
72 \text { horas } \\
\text { Lise celular com tampão D para afinidade } \\
\text { ao níquel e tampão E para afinidade ao } \\
\text { ATP }\end{array}$ & $\begin{array}{l}\checkmark \text { Proteína de } 43 k D a \text { se ligou à } \\
\text { coluna de afinidade ao níquel e foi } \\
\text { eluída em soluções de imidazol } 20 \\
\text { e } 50 \mathrm{mM} \text {, proteína de } 100 \mathrm{kDa} \text { se } \\
\text { ligou e foi eluída em solução de } \\
\text { imidazol } 20 \mathrm{mM} \\
\checkmark \text { Proteína de } 43 \mathrm{kDa} \text { se ligou à } \\
\text { coluna de afinidade ao ATP e foi } \\
\text { eluída em solução de NaCl } \\
100 \mathrm{mM} \text {, assim como a proteína } \\
\text { de } 100 \mathrm{kDa} \\
\checkmark \text { Os resultados possibilitaram a } \\
\text { análise da CDK13 por Western } \\
\text { Blot }\end{array}$ \\
\hline
\end{tabular}

\subsection{Western Blot}

Foi realizada a expressão da proteína CDK13 em células Rosetta(DE3) transformadas com plasmídeo sintético e indução com 0,2mM de IPTG, por 72 horas a $20^{\circ} \mathrm{C}$, em meio de auto-indução. Uma amostra da fração sobrenadante foi utilizada na purificação em coluna de afinidade ao ATP, na qual, proteínas 
de $43 \mathrm{kDa}$ e $100 \mathrm{kDa}$ foram eluídas em solução de $\mathrm{NaCl} 100 \mathrm{mM}$. Outra amostra da fração sobrenadante foi utilizada na purificação em coluna de afinidade ao $\mathrm{Ni}^{2+}$, e a proteína de $43 \mathrm{kDa}$ foi eluída em solução de imidazol $20 \mathrm{mM}$. A fração sobrenadante, o eluído em solução de $\mathrm{NaCl} 100 \mathrm{mM}$ e o eluído em solução de imidazol 20mM foram submetidos ao Western Blot.

A fração sobrenadante da expressão em células Rosetta(DE3) transformadas com plasmídeo sintético modificado e indução com $0,2 \mathrm{mM}$ de IPTG, por 24 horas a $20^{\circ} \mathrm{C}$, feita em meio LB, também foi utilizada no Western Blot para possível detecção da proteína CDK13 de aproximadamente $39 \mathrm{kDa}$.

Pelas Figuras 53 e 54 se observa que a proteína de aproximadamente $43 \mathrm{kDa}$ foi detectada na fração sobrenadante da expressão em meio de autoindução, assim como na eluição com imidazol. Se observa que a quantidade de proteína detectada no sobrenadante da expressão em meio de auto-indução foi muito alta, isso por que foi aplicado aproximadamente $30 \mu \mathrm{L}$ da amostra no gel de poliacrilamida, sendo assim, houve a saturação do gel pela amostra. Entretanto, isto não prejudicou a sua análise por Western Blot, pois, no experimento realizado, apenas foi identificada a proteína que contém cauda de histidina, a CDK13.

A proteína da fração solúvel da indução em meio LB com plasmídeo modificado não foi detectada.

A amostra da eluição com $\mathrm{NaCl}$ tinha pouca proteína, por isso, esta amostra foi concentrada em concentrador MilliPore $22 \mu \mathrm{m}$. O volume foi reduzido a $1 / 3$ do volume inicial, e foi aplicado aproximadamente $30 \mu \mathrm{L}$ da amostra no gel. Entretanto, ainda assim, a proteína não foi detectada. Isto indica que a proteína CDK13 que se ligou à coluna de afinidade ao ATP, talvez não estivesse sendo produzida em sua estrutura nativa, ou que a concentração de proteína era muito baixa e assim não foi possível transferir quantidade suficiente para a membrana de nitrocelulose que pudesse ser detectada pelo anticorpo. 
Figura 53 - Membrana de nitrocelulose do experimento de Western Blot para análise da CDK13 expressa em meio de auto-indução. 1: Marcador Unstained Protein Molecular Weight Marker. 2: Fração sobrenadante de células Rosetta(DE3), plasmídeo sintético. 3: Eluição com $\mathrm{NaCl} 100 \mathrm{mM}$ em que apareceu pequena quantidade de proteína de aproximadamente $43 \mathrm{kDa}$ e a de aproximadamente $100 \mathrm{kDa}$, porém as proteínas não foram detectadas por Western blot nesta amostra.

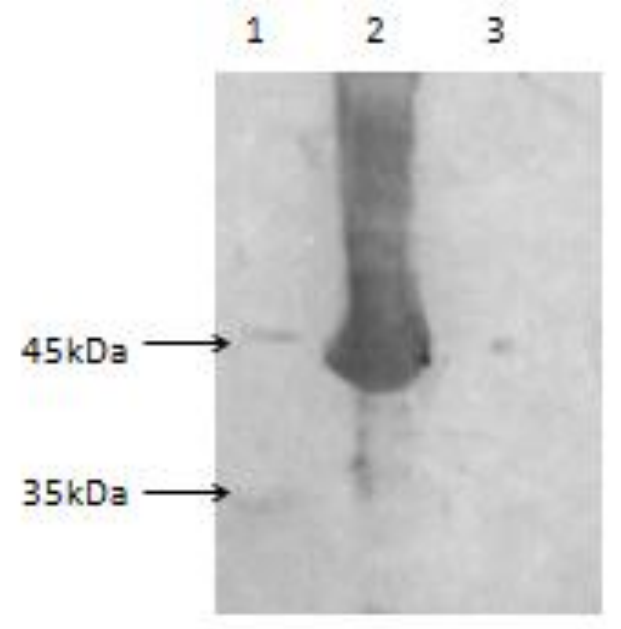

Fonte: Autoria própria.

Figura 54 - Membrana de nitrocelulose do experimento de Western Blot para análise da CDK13. 1: Marcador Unstained Protein Molecular Weight Marker. 2: Eluição com imidazol $20 \mathrm{mM}$ em que apareceu a proteína de aproximadamente $43 \mathrm{kDa}$. 3: Fração sobrenadante de células Rosetta(DE3), plasmídeo modificado, a proteína não foi detectada pelo Western Blot.

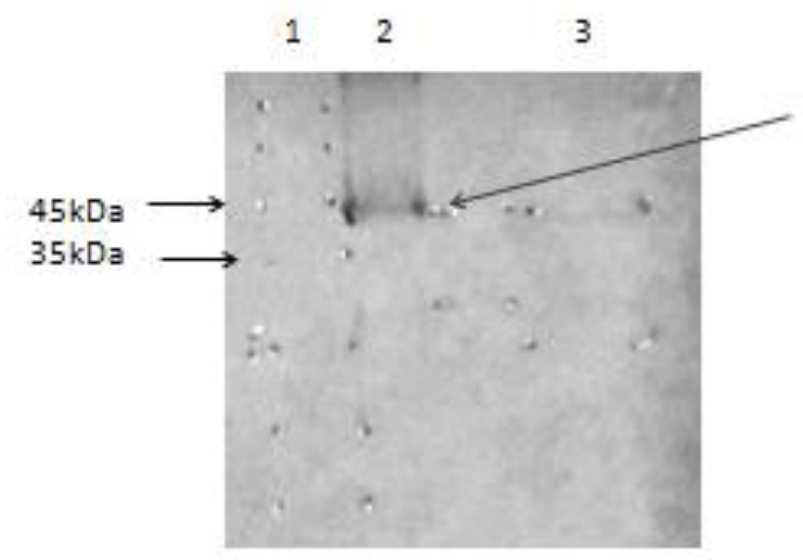

Fonte: Autoria própria.

Os principais resultados para os experimentos de Western Blot estão na Tabela 19. 
Tabela 19 - Principais resultados dos experimentos de Western Blot.

\begin{tabular}{|c|c|}
\hline Condições experimentais & Resultados obtidos \\
\hline $\begin{array}{l}\text { Sobrenadante da expressão em Rosetta(DE3) } \\
\text { transformada com plasmídeo sintético e indução } \\
\text { com 0,2mM de IPTG, por } 72 \text { horas a } 20^{\circ} \mathrm{C} \text {, em } \\
\text { meio de auto-indução, proteína de } \sim 43 \mathrm{kDa} \text {. }\end{array}$ & $\begin{array}{l}\checkmark \text { Proteína de } \sim 43 \mathrm{kDa} \text { foi } \\
\text { detectada }\end{array}$ \\
\hline $\begin{array}{l}\text { Eluído com NaCl 100mM (proteína de } \sim 43 \mathrm{kDa} \text { e } \\
\text { de } \sim 100 \mathrm{kDa} \text { ), da expressão em Rosetta(DE3) } \\
\text { transformadas com plasmídeo sintético e indução } \\
\text { com 0,2mM e IPTG, por } 72 \text { horas a } 20^{\circ} \mathrm{C} \text {, em } \\
\text { meio de auto-indução. }\end{array}$ & $\begin{array}{l}\checkmark \text { Proteínas não foram } \\
\text { detectadas }\end{array}$ \\
\hline $\begin{array}{l}\text { Eluído com imidazol } 20 \mathrm{mM} \text { (proteína de } \sim 43 \mathrm{kDa} \text { ), } \\
\text { da expressão Rosetta(DE3) transformadas com } \\
\text { plasmídeo sintético e indução com 0,2mM e } \\
\text { IPTG, por } 72 \text { horas a } 20^{\circ} \mathrm{C} \text {, em meio de auto- } \\
\text { indução. }\end{array}$ & $\begin{array}{l}\checkmark \text { Proteína de } \sim 43 \mathrm{kDa} \text { foi } \\
\text { detectada }\end{array}$ \\
\hline $\begin{array}{c}\text { Fração sobrenadante da expressão em } \\
\text { Rosetta(DE3) transformadas com plasmídeo } \\
\text { sintético modificado e indução com } 0,2 \mathrm{mM} \text { de } \\
\text { IPTG, por } 24 \text { horas a } 2^{\circ} \mathrm{C} \text {, em meio LB, proteína } \\
\text { de } \sim 39 \mathrm{kDa} \text {. }\end{array}$ & $\checkmark$ Proteína não foi detectada \\
\hline
\end{tabular}

A proteína CDK13 obtida com o plasmídeo sintético em todos os experimentos apresentava-se com aproximadamente $43 \mathrm{kDa}$, enquanto que o esperado era aproximadamente $99 \mathrm{kDa}$. Em apenas dois testes de expressão foi observada a expressão da proteína íntegra de $99 \mathrm{kDa}$, em células BL21(DE3) e Rosetta(DE3).

O site http://www.genscript.com/cgi-bin/tools/rare_codon_analysis, possibilita a análise da viabilidade da expressão da proteína de interesse em $E$. coli. Foi utilizada a ferramenta de análise de códons raros que calcula algumas propriedades como CAl e porcentagem de GC (guanina e citosina).

O CAI (Codon Adaptation Index) fornece uma indicação da viabilidade de um DNA codificante de uma proteína ser expresso em determinado organismo. O CAl considera a presença de códons raros para o organismo no 
DNA codificante, e que poderiam dificultar a expressão da proteína referente ao DNA codificante. O valor de CAI considerado ideal é 1 , e considerado bom quando maior que 0,8. A porcentagem de GC ideal é de 30 a $70 \%$. As regiões da sequência de DNA codificante que divergem destes valores podem afetar a eficiência de sua transcrição e tradução em E. coli. ${ }^{69}$

Os valores de CAI foram calculados para a proteína CDK13 obtida a partir do plasmídeo sintético, incluindo a cauda de histidina (proteína inteira); para a região de aproximadamente $43 \mathrm{kDa}$, desprezando a cauda de histidina (proteína $43 \mathrm{kDa}$ ); para a região $\mathrm{N}$-terminal, a qual corresponde a região expressa e considera a cauda de histidina (N-Terminal); e para a região Cterminal, a região que não foi expressa. A Figura 55 mostra o gráfico do valor de CAl para a região $\mathrm{N}$-terminal, como exemplo, e a Tabela 20 apresenta os valores obtidos para as regiões comentadas.

Figura 55 - Distribuição da frequência do uso de códons ao longo da sequência do DNA referente à CDK13 a ser expressa em E.coli. O valor de CAl 1,0 é considerado ideal, enquanto um CAI maior que 0,8 é considerado bom.

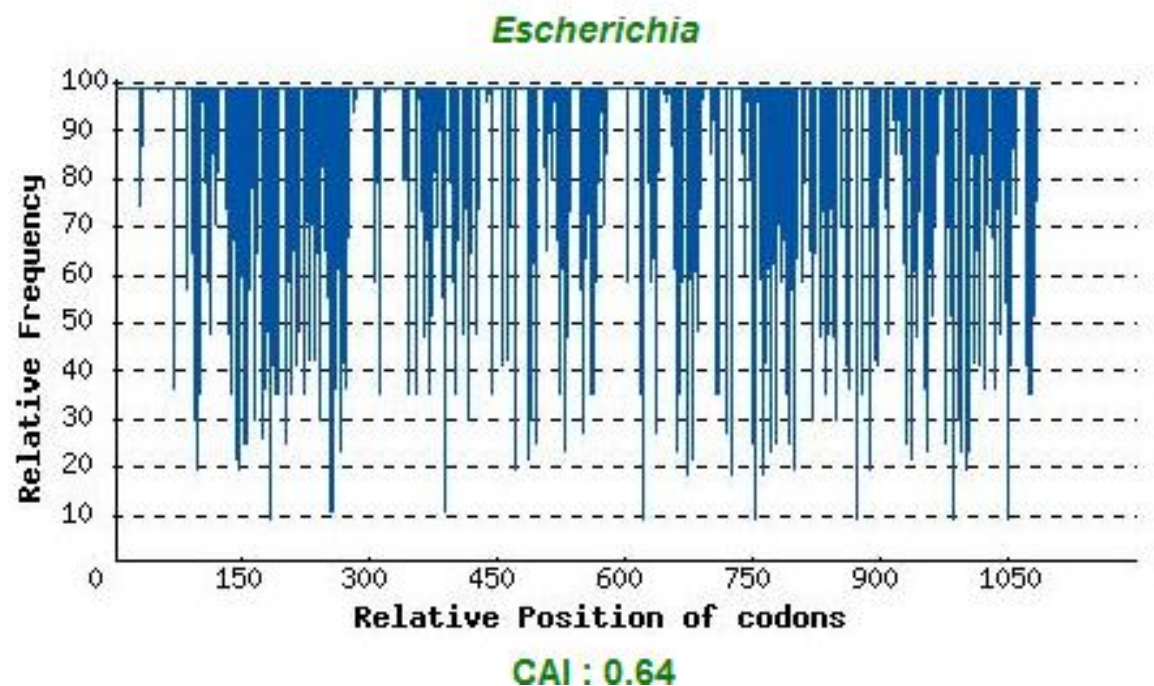

CAI : 0.64

Fonte: GENSCRIPT., GenScript Rare Codon Analysis Tool. 2002. ${ }^{69}$ 
Tabela 20 - Valores de CAI e porcentagem de GC para diferentes regiões da CDK13.

\begin{tabular}{c|c|c}
\hline Região & CAI & GC (\%) \\
\hline Proteína inteira & 0,60 & 44 \\
\hline Proteína 43kDa & 0,61 & 48 \\
\hline N-terminal & 0,64 & 51 \\
\hline C-terminal & 0,58 & 39 \\
\hline
\end{tabular}

O valor de CAl obtido para a proteína inteira e para a de $43 \mathrm{kDa}$ foram baixos, já que o valor mais próximo de 1 indica melhor expressão da proteína de interesse em $E$. coli.

$\mathrm{O}$ valor para a região $\mathrm{N}$-terminal foi o maior, e como, quanto maior $\mathrm{O}$ número de $\mathrm{CAI}$, maior a chance do DNA ser expresso, esse resultado concorda com os resultados obtidos, de que apenas a região $\mathrm{N}$-terminal da proteína foi expressa. (A proteína obtida foi submetida à purificação em coluna de $\mathrm{Ni}^{2+}$, e se ligou à coluna, como mostrado no item 4.4.2 Purificação da CDK13 da expressão em meio de auto-indução com plasmídeo sintético, mostrando que a proteína expressa se trata da região $\mathrm{N}$-terminal, a qual contém a cauda de histidina).

A região C-terminal possui o menor valor de $\mathrm{CAl}$, o que indica que esta região é a que possui maiores dificuldades para ser expressa, devido à presença de códons raros.

Portanto, a partir dos valores de CAl, é possível entender o motivo de a proteína ter sido expressa em células Rosetta(DE3), as quais fornecem t-RNAs para códons raros em E. coli, e das células BL21(DE3)pTGroE, BL21(DE3)pLysS, BL21(DE3)pLysE e Origami(DE3) não terem melhorado o padrão de expressão. Os resultados também indicam que plasmídeo sintético não teve a minimização da presença de códons raros por engenharia genética para facilitar sua expressão em E. coli, como foi prometido pelo fabricante. 


\section{CONCLUSÕES}

O DNA correspondente à CDK13 foi clonado em vetor de clonagem pCR-Blunt, porém não foi possível liberá-lo para sua posterior ligação em vetor de expressão.

Sendo assim, o plasmídeo pET28a::CDK13 foi sintetizado comercialmente, tornando possível a expressão da proteína CDK13. Ainda assim, a proteína foi parcialmente expressa, em tamanho menor que o esperado $(\sim 43 \mathrm{kDa})$. A dificuldade encontrada foi provavelmente devido à presença de muitos códons raros no DNA referente à CDK13. Análise por bioinformática mostrou a presença significativa de códons raros, os quais teoricamente seriam substituídos durante a síntese comercial. As posições dos códons raros ao longo da sequência nucleotídica revelaram a dificuldade de expressão em E. coli. A porção $3^{\prime}$ é mais rica nestes códons do que a porção 5', o que pode explicar a expressão do N-terminal da proteína. A proteína de aproximadamente $43 \mathrm{kDa}$ foi expressa em meio LB em células BL21(DE3), indução com $0,1 \mathrm{mM}$ de IPTG, a $30^{\circ} \mathrm{C}$, por 4 horas, a qual apresentou-se insolúvel após a lise celular. Testes de expressão também foram realizados utilizando meio de auto-indução, em células Rosetta(DE3), indução com $0,2 \mathrm{mM}$ de IPTG, 20ㅡ, por 72 horas, nos quais houve a expressão da CDK13 na sua forma parcialmente solúvel. Nesta condição, observou-se a expressão de proteínas de $43 \mathrm{kDa}$ e de $99 \mathrm{kDa}$, correspondentes a porção $\mathrm{N}$-terminal da CDK13 e à CDK13 inteira, respectivamente. Utilizando o meio de auto-indução, o qual permite a expressão de forma mais lenta, houve a expressão da CDK13 íntegra, porém com baixa reprodutibilidade. Ambas, a proteína de $43 \mathrm{kDa}$ e a de $99 \mathrm{kDa}$, se ligaram a coluna de afinidade ao níquel, e foram eluídas com solução de imidazol $20 \mathrm{mM}$. A CDK13 de $43 \mathrm{kDa}$ foi detectada por Western blot. Já a purificação utilizando coluna de afinidade ao ATP mostrou que ambas as proteínas expressas foram eluídas em $\mathrm{NaCl} 100 \mathrm{mM}$, porém não foram detectadas por Western Blot, o que não foi conclusivo, desde que não foi possível refazer o experimento de imunodetecção. 
Outra tentativa de melhorar o padrão de expressão na sua forma solúvel e enovelada foi realizar uma modificação no plasmídeo sintético, o qual foi feito por PCR utilizando primers específicos que delimitassem a região do bolsão de ligação do ATP, que envolve o domínio quinase. Para escolha desta região foram realizadas análises comparativas com estruturas resolvidas de outras CDKs, as quais possuem a resolução cristalográfica justamente da região do domínio quinase. Esta análise demonstrou a real dificuldade de se expressar CDKs em sistemas bacterianos, porém a possibilidade de conseguir expressar o domínio quinase de forma solúvel e estruturado. Os testes realizados em Rosetta(DE3) utilizando meio LB resultaram na expressão do domínio quinase, porém não foi possível separá-lo por cromatografia de afinidade ao níquel.

Sendo assim, os resultados mostraram que o sistema bacteriano foi capaz de produzir a proteína CDK13, porém em concentrações insuficientes para testes de atividade. Mais testes deverão ser realizados com o objetivo de estabelecer a melhor condição de expressão, tanto da CDK13 de 99 kDa, quanto do domínio quinase de 38,9 kDa. Testes de expressão em sistema eucariótico, como em leveduras, também serão realizados. 


\section{REFERÊNCIAS BIBLIOGRÁFICAS}

1 NELSON, D. L.; COX, M. M. Princípios de bioquímica de Lehninger. 5. ed. Porto Alegre: Artmed, 2011. 1273 p.

2 ALBERTS, B.; JOHNSON, A.; LEWIS, J.; RAFF, M.; ROBERTS, K; WALTER, P. Biologia molecular da célula. 5. Ed. São Paulo: Artmed, 2010. 1268 p.

3 VOET, D.; VOET, G. J. Bioquímica. 3. ed. Porto Alegre: Artmed, 2006. 1596 p.

4 GALLORINI, M.; CATALDI, A.; GIACOMO, V. Cyclin-dependent kinase modulators and cancer therapy. Biodrugs, v. 26, n. 6, p. 377-391, 2012.

5 MALUMBRES, M.; HARLOW, E.; HUNT, T.; HUNTER, T.; LAHTI, J. M.; MANNING, G. MORGAN, D. O.; TSAI, LI-HUEI.; WOLGEMUTH, D. J. Cyclin dependent kinases: a family portrait. Nature Cell Biology, v. 11, n. 11, p. 12751276, 2009.

6 GERARD, M.; GOLDBETER, A. A skeleton model for the network of cyclindependent kinases driving the mammalian cell cycle. Interface Focus, v. 1, p. 24-35, 2011.

7 WIKIMEDIA. Serina. 2011. Disponível em:

<http://upload.wikimedia.org/wikipedia/commons/e/e2/L-serine-skeletal.png>. Acesso em: 30 nov. 2013.

8 WIKIMEDIA. Trifosfato de adenosina. 2013. Disponível em:

<http://upload.wikimedia.org/wikipedia/commons/7/78/ATP

structure_revised.png >. Acesso em: 30 nov. 2013.

9 WIKIMEDIA. Phosphoserine. 2013. Disponível em:

<http://upload.wikimedia.org/wikipedia/commons/e/e4/L-Phosphoserine.png>. Acesso em: 30 nov. 2013.

10 BERTHET, C.; KALDIS, P. Cell-specific responses to loss of cyclindependent kinases. Oncogene, v. 26, p. 4469-4477, 2007.

11 MORGAN, D. O. Principles of CDK regulation. Nature, v. 374, p. 131-134, 1995.

12 SHAPIRO, G. I.; HARPER, W. Anticancer drug targets: cell cycle and checkpoint control. The Journal of Clinical Investigation, v. 104, n. 12, p. 1645-1653, 1999. 
13 AZEVEDO, W. F.; LECLERC, S.; MEIJER, L.; HAVLICEK, L.; STRNAD, M.; KIM, S. Inhibition of cyclin-dependent kinases by purine analogues: Crystal structure of human cdk2 complexed with roscovitine. European Journal of Biochemistry, v. 243, p. 518-526, 1997.

14 MORGAN, O. D. Cyclin-dependent kinases: Engines, clocks, and microprocessors. Annual Review of Cell and Developmental Biology, v. 13, p. 261-291, 1997.

$15 \mathrm{LI}$, A.; BLOW, J. J. The origin of CDK regulation. Nature Cell Biology, v. 3, p. 182-184, 2001.

16 MCGRATH, D.; BALOG, E. R. M.; KOIVOMAGI, M.; LUCENA, R.; MAI, M. V.; HIRSCHI, A.; KELLOG, D. R.; LOOG, M.; RUBIN, S. M. Cks confers specificity to phosphorilation-dependent CDK signaling pathways. Nature Structural \& Molecular Biology, v. 20, n. 12, 20013.

17 EVEN, Y.; DURIEUX, S.; ESCANDE, M.; LOZANO, J. C.; PEAUCELLIER, G.; WEIL, D.; GENEVIÈRE, A. CDC2L5, a Cdk-line kinase with RS domain interacts with the ASF/SF2-associated protein p32 and affects splicing in vivo. Journal of Cellular Biochemistry, v. 99, p. 890-904, 2006.

18 KOHOUTEK, J.; BLAZEK, D. Cyclin K goes with Cdk12 and Cdk13. Cell Division, v. 7, n. 12, p. 1-10, 2012.

19 FAJAS, L. Re-thinking cell cycle regulators: the cross-talk with metabolism. Frontiers in Molecular and Cellular Biology, v. 3, n. 4, p. 1-6, 2013.

20 MARQUES, F.; MOREAU, J. L.; PEAUCELLIER, G.; LOZANO, J. C.; SCHATT, P.; PICARD, A. CALLEBAUT, I.; PERRET, E.; GENEVIERE, A. M. A new subfamily of high molecular mass CDC2-related kinases with PITAI/VRE motifs. Biochemical and Biophysical Research Communications, v. 219, p. 832-837, 2000.

21 DAI, Q.; LEI, T.; ZHAO, C.; ZHONG, J.; TANG, Y.; CHEN, B.; YANG, J.; LI, C.; WANG, S.; SONG, X.; LI, L. LI, Q. Cyclin K-containing kinase complexes maintain self-renewal in murine embryonic stem cells. Journal of Biological Chemistry, v. 287, p. 25344-25352, 2012.

22 CHEN, H.; WANG, Y.; FANN, M. Identification and characterization of the CDK12/Cyclin L1 complex involved in alternative splicing regulation. Molecular and Cellular Biology, v. 26, n. 7, p. 2736-2745, 2006.

23 CHEN, H. H.; WONG, Y. H.; GENEVIERE, A. M.; FANN, M. J.

CDK13/CDC2L5 interacts with L-Type cyclins and regulates alternative splicing. Biochemical and Biophysical Research Communications, v. 354, p. 735740, 2007. 
24 BLAZEK, D.; KOHOUTEK, J. BARTHOLOMEEUSEN, K.; JOHANSEN, E.; HULLINKOVA, P.; LUO, Z. CIMERMANCIC. P.; ULE, J.; PETERLIN, M. The cyclin $\mathrm{K} /$ Cdk12 complex maintains genomic stability via regulation of expression of DNA damage response genes. Genes \& Development, v. 25, p. 2158-2172, 2011.

25 BARTKOWIAK, B.; LIU, P.; PHATNANI, H. P.; FUDA, N. J.; COOPER, J. J. CDK12 is a transcription elongation associated CTD kinase, the metazoan ortholog of yeast Ctk1. Genes \& Development, v. 24, p. 2303-2316, 2010.

26 NI, Z.; OLSEN, J. B.; GUO, X.; ZHONG, G.; RUAN, E. D.; MARCON, E.; YOUNG, P.; GUO, H.; LI, J.; MOFFAT, J.; EMINILI, A. GREENBLATT, J. F. Control of the RNA polymerase II phosphorilation state in promoter regions by CTD interaction domain-containing proteins RPRD1A and RPRD1B. Landes Bioscience Transcription, v. 2, n. 5, p. 237-242, 2011.

27 NECHAEV, S.; ADELMAN, K. Pol II waiting in the starting gates: regulating the transition from transcription initiation into productive elongation. Biochimica et Biophysica Acta, v. 1809, p. 34-45, 2012.

28 BARTKOWIAK, B.; GREENLEAF, A. L. Phosphorilation of RNAPII To PTEFb or not to P-TEFb? Landes Bioscience, v. 2, n. 3, p. 115-119, 2011.

29 COLE, M. D.; COWLING, V. H. Transcription-independent functions of MYC: regulation of translation and DNA replication. Nature Reviews Molecular Cell Biology, v. 9, p. 810-815, 2008.

30 BERRO, R.; PEDATI, C.; KEHN-HALL, K.; WU, W.; KLASE, Z.; EVEN, Y.; GENEVIĖRE, A.; AMMOSOVA, T.; NEKHAI, S.; KASHANCHI, F. CDK13, a new potential human immunodeficiency virus type 1 inhibitory factor regulating viral mRNA splicing. Journal of Virology, v. 82, n. 14, p. 7155-7166, 2008.

31 MAAS, S.; SIE, C. P. G.; STOEV, I. DUPUIS, D. E.; LATONA, J.; PORMAN, A.M., EVANS, B.; REKAWEK, P.; KLUEMPERS, V.; MUTTER, M.; GOMMANS, W. M.; LOPRESTI, D. Genome-wide evaluation and discovery of vertebrate Atol RNA editing sites. Biochemical and Biophysical Research Communications, v. 412, p. 407-412, 2011.

32 BAKRE, A.; ANDERSEN, L. E.; MELIOPOULOS, V.; COLEMAN, K.; YAN, X. BROOKS, P.; CRABTREE, J.; TOMPKINS, M.; TRIPP, R. A. Identification of host kinase genes required for Influenza virus replication and the regulatory role of MicroRNAs. PLOS ONE, v. 8, n. 6, p. 1-16, 2013.

33 KIM, H. E.; KIM, D. G.; LEE, K. J.; SON, J. G.; SONG, M. Y.; PARK, Y. M.; KIM, J. J.; CHO, S. W.; CHI, S. G.; CHEONG, H. S.; SHIN, H. D.; LEE, S. W.; LEE, J. K. Frequent amplification of CENPF, GMNN and CDK13 genes in hepatocellullar carcinomas. PLOS ONE, v. 7, n. 8, p. 1-10, 2012. 
34 SIGMA-ALDRICH. Tamoxifen. 2013. Disponível em:

$<$ http://www.sigmaaldrich.com/catalog/product/sigma/t5648?lang=pt\&region=B

R>. Acesso em: 16 jan. 2014.

35 BENSON, C.; KAYE, S.; WORKMAN, P.; GARRET, M.; WALTON, M.; BONO, J.; Clinical anticancer drug development: targeting the cyclin-dependent kinases. British Journal of Cancer, v. 92, p. 7-12, 2005.

36 BAUMLI, S.; LOLLI, G.; LOWE, E. D.; TROIANI, S.; RUSCONI, L.; BULLOCK, A. N.; DEBRECZENI, J. E.; KNAPP, S.; JOHNSON, L. N. The structure of P-TEFb (CDK9/Cyclin T1), its complex with flavopiridol and regulation by phosphorilation. European Molecular Biology Organization, $v$. 27, p. 197-1918, 2008.

37 AZEVEDO, W. F.; MUELLER-DIECKMANN, H.; SHULZE-GAHMEN, U.; WORLANDT, P. J.; SAUSVILLET, E.; KIM, S. Structural basis for specificity and potency of a flavonoid inhibitor of human CDK2, a cell cycle kinase.

Proceedings of the National Academy of Sciences, v. 23, p. 2735-2740, 1996.

38 PEREIRA, Larissa Miranda. Clonagem, expressão, purificação e caracterização da proteína ribossomal L10 humana recombinante. 2009. 87 f. Dissertação (Mestrado em Ciências na área de Tecnologia Nuclear)Instituto de Pesquisas Energéticas e Nucleares, São Paulo, 2009.

39 JEMAL, A.; BRAY, F.; CENTER, M. M.; FERLAY, J. WARD, E.; FORMAN, D. Global cancer statistics. CA: A Cancer Journal for Clinicians, v. 61, n. 2, p. 69-90, 2011.

40 WORLD HEALTH ORGANIZATION (WHO). Are the number of cancer cases increasing or decreasing in the world? 2008. Disponivel em:

<http://www.who.int/features/qa/15/en/index.html>. Acesso em: 28 nov. 2013.

41 SEFRINN, J. R.; HILL, D.; BURKART, W.; MAGRATH, I.; BADWE, R. A.; NGOMA, T.; MOHAR, A.; GREY, N. It is time to include cancer and other noncommunicable diseases in the millennium development goals. A Cancer Journal for Clinicians, v. 59, p. 282-284, 2009.

42 WORLD HEALTH ORGANIZATION (WHO). World cancer report 2008. 2008. p. 1-260.

43 INSTITUTO NACIONAL DE CÂNCER (INCA). Câncer matou 8,2 milhões de pessoas em 2012, diz OMS. 2012. Disponível em:

<http://www2.inca.gov.br/wps/wcm/connect/agencianoticias/site/home/notnotic/ 2013/caner_matou_8\%2C2_milhoes_diz_oms>. Acesso em: 28 nov. 2013.

44 WORLD HEALTH ORGANIZATION (WHO). Cancer Fact Sheet no 297. 2013. Disponível em: <http://www.who.int/mediacentre/factsheets/fs297/en/>. Acesso em: 28 nov. 2013. 
45 INSTITUTO NACIONAL DE CÂNCER (INCA). INCA e Ministério da Saúde apresentam estimativas de câncer para 2014. 2014. Disponível em:

<http://www2.inca.gov.br/wps/wcm/connect/agencianoticias/site/home/notnotic/ 2013/inca_ministerio_saude_apresentam_estimativas_cancer_2014>. Acesso em: 28 nov. 2013.

46 INSTITUTO NACIONAL DE CÂNCER (INCA). Maioria dos países em desenvolvimento não tem políticas eficazes de prevenção de câncer. 2013. Disponível em:

<http://www2.inca.gov.br/wps/wcm/connect/agencianoticias/site/home/notnotic/ 2013/maioria_dos_paises_desenvolvimento_nao_tem_politicas_eficaefi_de_pr evencao_cancer>. Acesso em: 28 nov. 2013.

47 BODE, A. M.; DONG, Z. Cancer prevention research - then and now. Macmillan Publishers Nature, v. 9, p. 508-516, 2009.

48 PEDRAZA-FARIÑA, L. G. Mechanisms of oncogenic cooperation in cancer initiation and metastasis. Yale Journal of Biology and Medicine, v. 79, p. 95103, 2006.

49 HANAHAN, D.; WEINBERG, R. A. The hallmarks of cancer review. Cell Press, v. 100, p. 57-70, 2000.

50 NOWELL, P. C. Mechanisms of tumor progression. Cancer Research, v. 46, p. 2203-2207, 1986.

51 FUTREAL, P. A.; COIN, L.; MARSHALL, M.; DOWN, T.; HUBBARD, T.; WOOSTER, R.; RAHMAN, N.; STRATION, M. A census of human cancer genes. Nature Reviews Cancer, v. 4, n. 3, p. 177-183, 2004.

$52 \mathrm{CHOW}, \mathrm{A}$. Cell Cycle control by oncogenes and tumor supressors: driving the transformation of normal cells into cancerous cells. Nature Education, v. 3, n. 9, p. 7, 2010. Disponível em: < http://www.nature.com/scitable/topicpage/cellcycle-control-by-oncogenes-and-tumor-14191459>. Acesso em: 10 dez. 2013.

53 KINZLER , K. W.; VOGELSTEIN, B. Lessons from hereditary colorectal cancer. Cell, v. 87, p. 159-170, 1996.

54 HAHN, W. C. WEINBERG, R. A. Rules for making human tumor cells. New England Journal of Medicine, v. 347, n. 20, p. 1593-1603, 2002.

55 HUNTER, T. Cooperation between oncogenes. Cell Review, v. 64, p. 249270, 1991.

56 LODISH, H.; BERK, A.; ZIPURSKY, S. L.; MATSUDAIRA, P.; BALTIMORE, D.; DARNELL, J. Molecular cell biology. 4. ed. New York: Media Connected, 2000. p. 1063-1067. 
57 BISHOP, J. M. Molecular themes in oncogenesis. Cell Review, v. 64, p. 235-246, 1991.

58 BERG, J.M.; TYMOCZKO, J.L.; STRYER, L. Bioquímica. 6. ed. Rio de Janeiro: Guanabara Koogan, 2008. 1114 p.

59 CAMPBELL, M. K.; FARREL, S. O. Bioquímica. 5. ed. São Paulo: Thomson, 2007. v. 2, 509 p.

60 LEOPOLDINO, A. M.; CANDURI, F.; CABRAL, H.; JUNQUEIRA, M.; MARQUI, A. B. T.; APPONI, L. H.; FONSECA, I. O.; DOMONT, G. B.;

SANTOS, D. S.; VALENTINI, S.; BONILLA-RODRIGUEZ, G. O.; FOSSEY, M. A.; AZEVEDO, W. F.; TAJARA, E. H. Expression, purification and circular dichroism analysis of human CDK9. Protein Expression and Purification, v. 47, p. 614-620, 2006.

61 HOWE, C. Gene cloning and manipulation. 2. ed. Cambridge: Cambridge University, 1997. v. 2.

62 SAMBROOK, J.; RUSSEL, D. W. Molecular cloning: a laboratory manual. 3. ed. New York: Cold Spring Harbor Laboratory, 2001. v. 3.

63 STUDIER, W. F.; ROSENBERG, A. H.; DUNN, J. J.; DUBENDORFF, J.W. Use of T7 RNA polymerase to direct expression of cloned genes. Methods in Enzymology, v. 185, p. 60-89, 1990.

64 NOVAGEN. pET System Manual: the GOLD standard for protein expression. Darmstadt: EMD Biosciences, 2005. 80 p.

65 GROISILLIER, A.; HERVE, C.; JEUDY, A.; REBUFFET, E. PLUCHON, P. F.; CHEVOLOT, Y.; FLAMENT, D.; GESLIN, C.; MORGADO, I. M.; POWER, D. BRANNO, M.; MOREAU, H. MICHEL, G.; BOYEN, C.; CZJZEK, M. Marineexpress: taking advantage of high troughput cloning and expression strategies for the post genomic analysis of marine organisms. Microbial Cell Factories, v. 9, n. 45, p. 2-11, 2010.

66 STUDIER, F. W. Protein production by auto-induction in high-density shaking cultures. Protein Expression and Purification, v. 41, p. 207-234, 2005.

67 MOREIRA, Juliana. Clonagem, expressão e purificação das quinases dependentes de ciclinas 10 e 13 humanas. 2011. $55 \mathrm{f}$. Trabalho de conclusão de curso (Química)-Instituto de Química de São Carlos, Universidade de São Paulo, São Carlos, 2011.

68 LIM, S.; KALDIS, P. Cdks, cyclins and CKIs: roles beyond cell cycle regulation. The Company of Biologists, v. 140, p. 3079-3093, 2013. 
69 GENSCRIPT: GenScript rare codon analysis tool. 2002. Disponível em: <http://www.genscript.com/cgi-bin/tools/rare_codon_analysis>. Acesso em: 05 jan. 2014. 